\title{
القواعد في نزول القرآن والقراءات وحفظها
}

\author{
إعداد \\ د/ محمد بن عبد الله بن صالح الضَّالع \\ الأستاذ المشارك في قسم القرآن وعلومه \\ كلية الثريعة والدراسات الإسلامية \\ جامعة القصيم
}


$-Y \leqslant 7-$ 
إن الحمد لله؛ نحمده، ونستعينه، ونستغفره، ونعوذ بالله من شرور

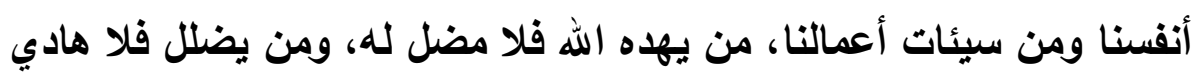
له، وأثشه أن لا إله إلا الله وحده لا شريك له، وأثشه أن محمداً عبده

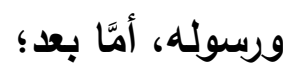

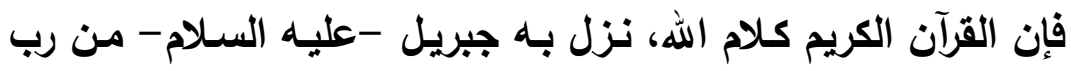

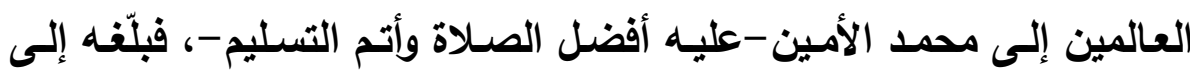

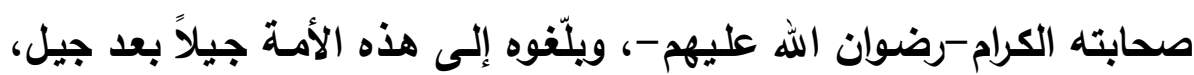
متواتراً محفوظاً منقولاً بالتلقي والمشافهة. وقد جعله الله معجزة باقية حيّة خالاة لهذه الأمسة، يحمل شريعتها وأصولها، ويرسم المنهج الرياني للعباد في أمور دينهم ودنياهم.

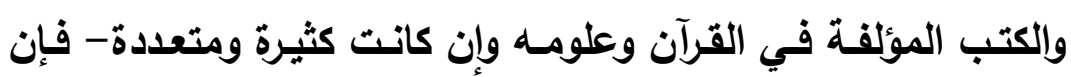

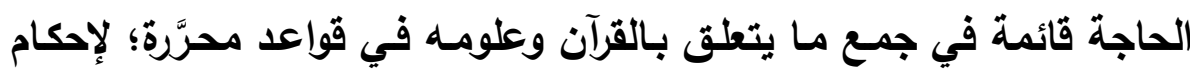

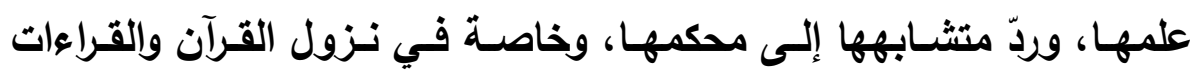
وحفظها ؛ ولذا كان اختيار هذا الموضوع وهو: ( القواعد في نزول فئس القرآن والقراءات وحفظها ).

وقت رأيت تقسيم البحث إلى مقدمة وفصلين وخاتمة، وجعلت في كل فصل

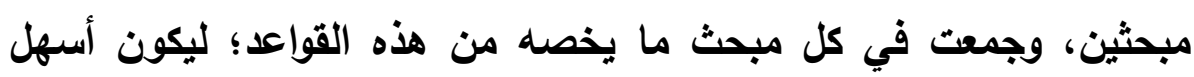
مطالعة وأكثر استحضاراً في الذهن. والخطة كالتالي : المقدمة .

التمهيد : التعريف بالقرآن والقراءات . 
الفصل الأول : القواعد في نزول القرآن وحفظه.

المبحث الأول : القواعد في نزول القرآن.

المبحث الثاني : القواعد في حفظ القرآن.

الفصل الثاني : القواعد في نزول القراءات وحفظها.

المبحث الأول : القواعد في نزول القراءات.

المبحث الثاني : القواعد في حفظ القراءات.

الخاتمة.

الفهارس.

منهجي في هذا البحث .

ألخص منهجي في هذا البحث بالنقاط التالية :

1- - أستخرج القواعد المتعلقة بالموضوع.

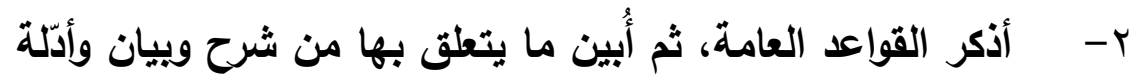

وأقوال لأهل العلم -حسب ما تقتضيه القاعدة، ثم أذكر -في مأفي

الغالب- بعض القواعد الفرعية التي تنذرج تحت كل لاعل قاعدة

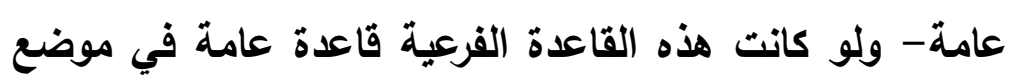

آخر.

r- اقتصرت على القواعد التي لها تعلّق بموضوع البحث-في

الغالب.

ع - رغبت بأن يكون هذا البحث يدور في فَلك كل قاعدة، بعيداً عن

الاستطراد إلا ما اقتضته الحاجة.

وصلى الله وسلم على نبينا محمد وعلى آله وصحبه أجمعين.

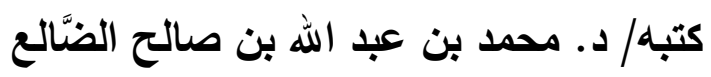

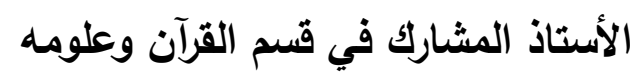




\section{تمهيد : التعريف بالقرآن والقراءات}

قبل الدخول في موضوع: القواعد في نزول القرآن والقراءات وحفظها يحسن التعريف بلفظ القرآن والقراعات من الناحية اللغوية والاصطلاحيةعلى وجه الإجمال فقط: التعريف بالقرآن: القرآن معناه في اللغة: القراءة والتتلاوة، يُقال قرأ قراءة وقرآناً، مصدر قرأ، على وزن فُعلان (1). القرآن معناه شرعاً واصطلاحاً: هو كلام الله تعالى، المعجز، المتعبد بتلاوته، الذي نزل به جبريل من رب العالمين على نبينا محمد، المنقول بالتواتر،

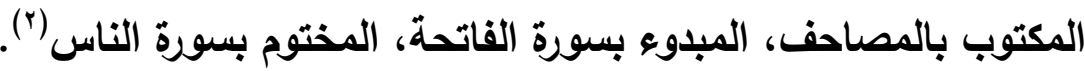

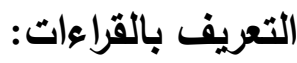
القراءات معناها في اللغة: جمع قراءة، مصدر قرأ، يُقال قرأ يقرأ قراءة، على

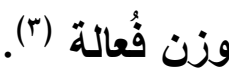
القراءات معناها في الاصطلاح: مذهب من مذاهب النطق بالقرآن الكريم،

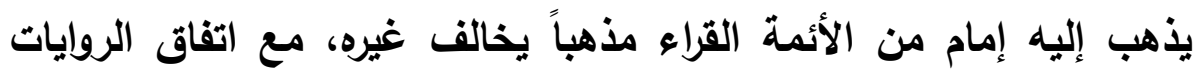

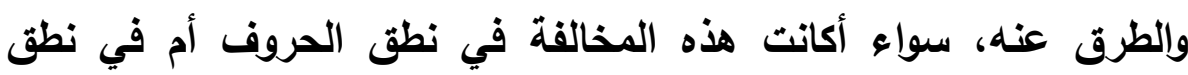

هيئاتها (๕) فئن

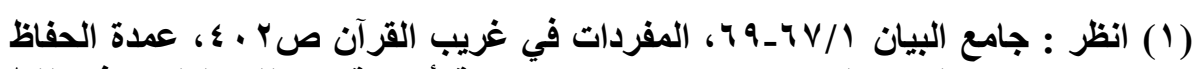

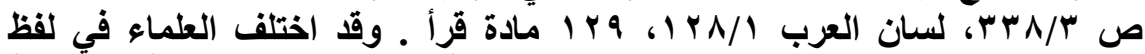

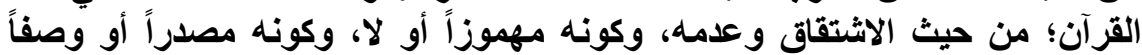

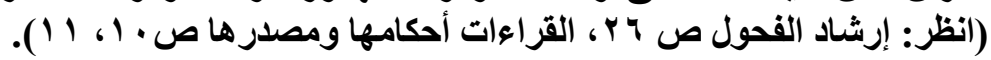

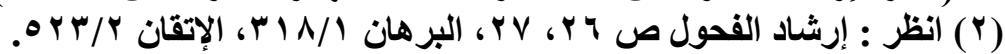

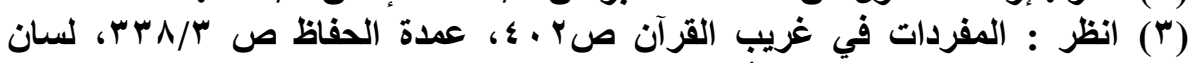


ويعرف أيضاً: بأنه علم بكيفية أداء كلمات القرآن وإختلافها بعزو الناقدة (1).

$$
\text { الفصل الأول : القواعد في نزول القرآن وحفظه أنهاء }
$$

المبحث الأول : القواعد في نزول القرآن

هذه بعض القواعد في نزول القرآن، والتي لها تعلّق بالقراءات، وهي:

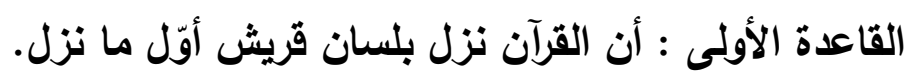

$$
\text { ومما يذل على ذلك : }
$$

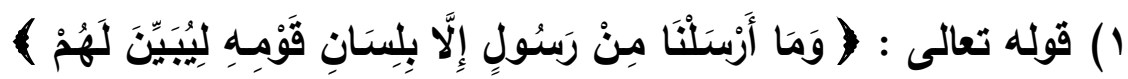

$$
\text { [إبراهيم : }
$$

وقريش قوم النبـي - صلـى الله عليهه وسـلم-، ولغته لغتهم، ولغنة

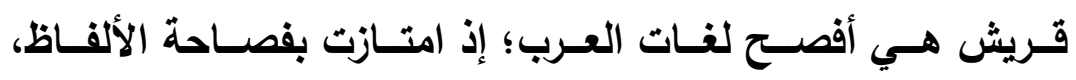
وسهولتها في النطق، وحسنها في السمع، وييانها عما في النفس .

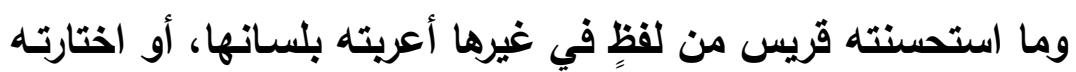
فصار من لغتها (؟).

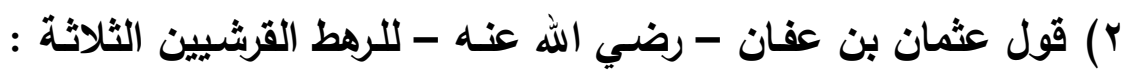

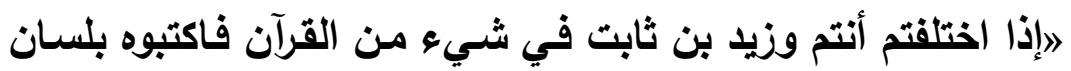

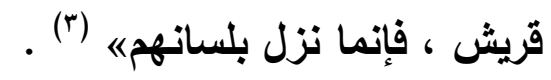

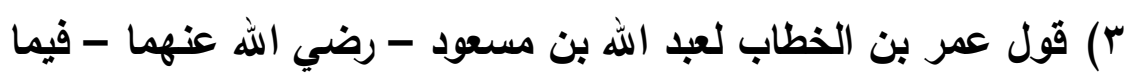

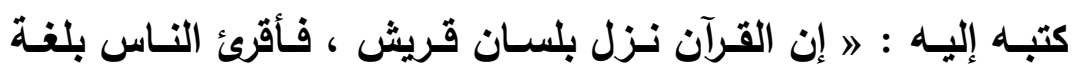

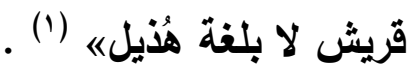

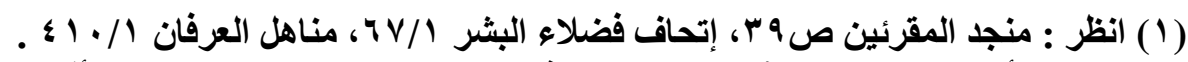

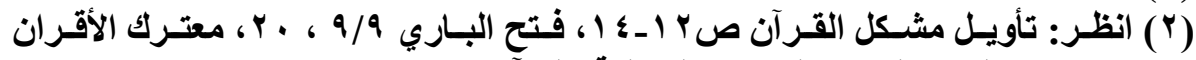

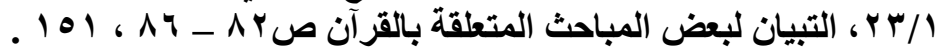

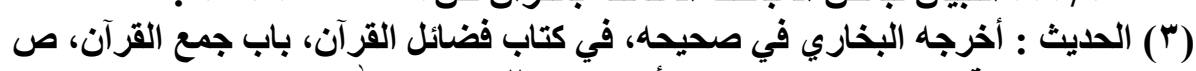

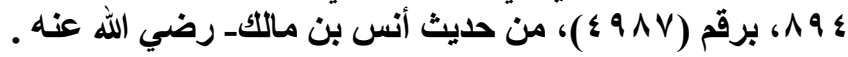


القاعدة الثانيـة : أن قراءة القرآن في العهد المكي بقيت على حرف واحد

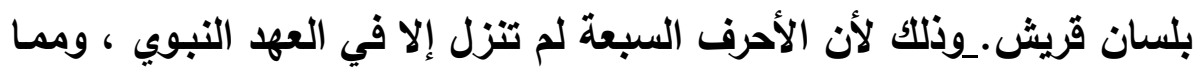

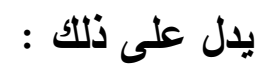

1) حليث أُبيّ بن كعب-رضي الله عنه-: " أن النبي - صلى الله عليه

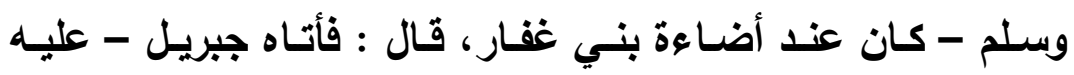

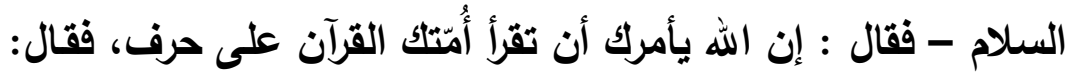

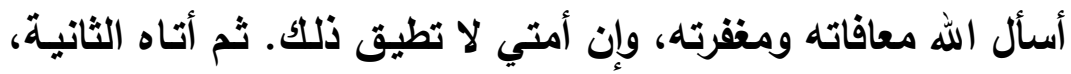

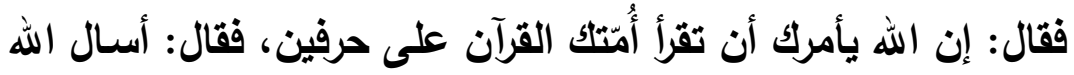

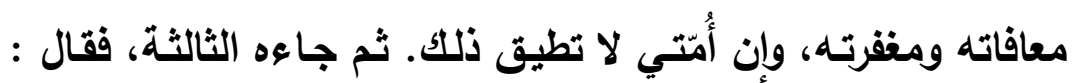

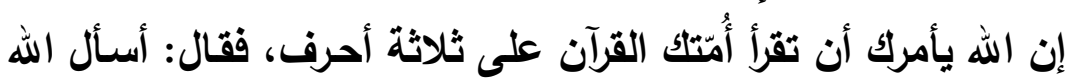

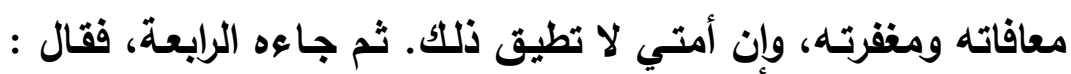

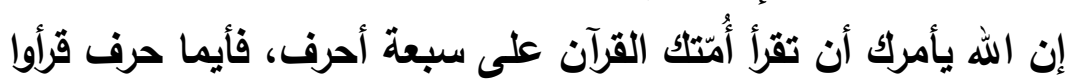

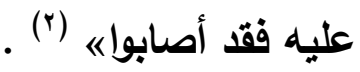

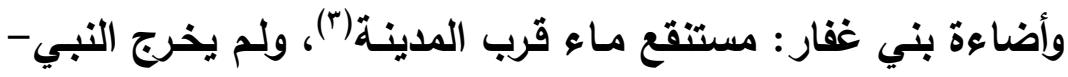

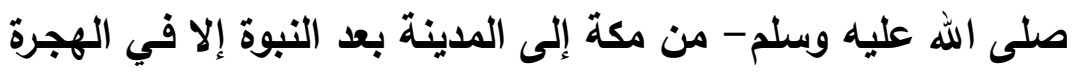

(1) الأثر : أخرجه ابن عبد البر في التمهيد YVA/A بسنده إلى أبي داود، من طريق كعب a

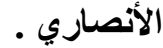

وقول عمر لابن مسعود في الإقراء بلغة قريش على سبيل الاختيار والأولى لمن أراد قراءة

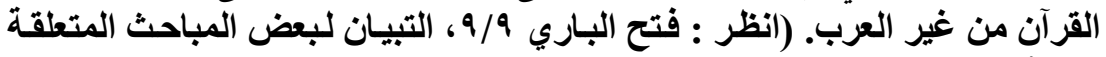

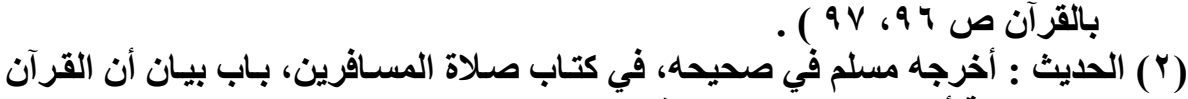

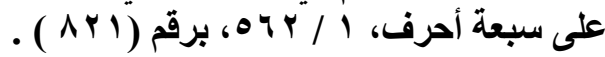

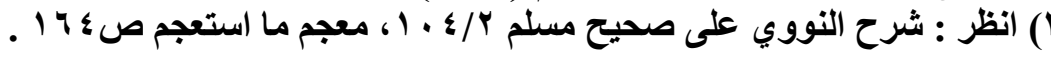


r أن اختلاف الصحابة في قراعة الأحرف السبعة وَقَع في المدينة، ولم

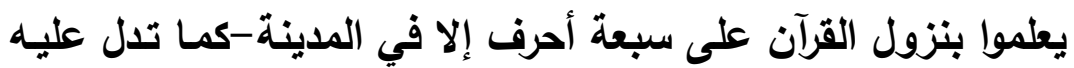

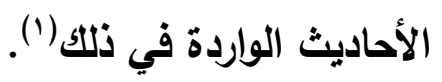

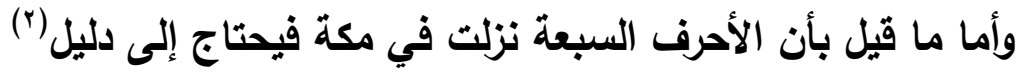
القاعدة الثالثة : أن القرآن يقع فيه النسخ.

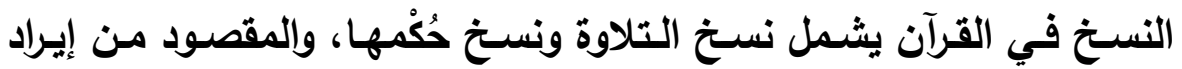
القاعدة هنا : نسخخ التلاوة . ومما يال على وقوع النسخ في القرآن :

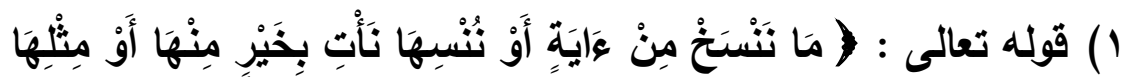

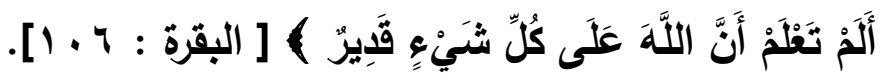

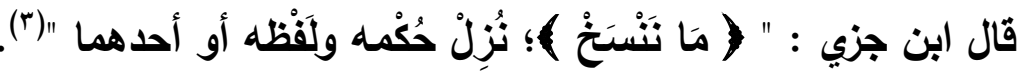

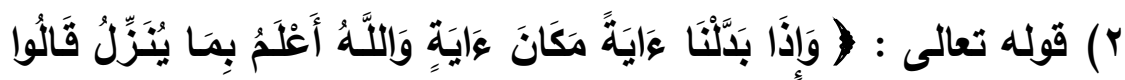

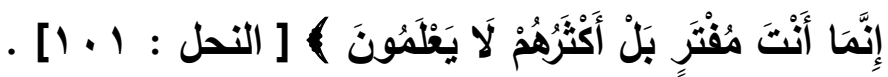

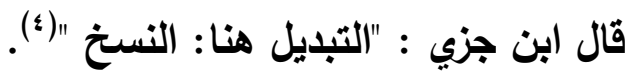
ومن الأمثلة على نسخ التلاوة : آية رجم الزاني المحصن، كما قال عمر بن

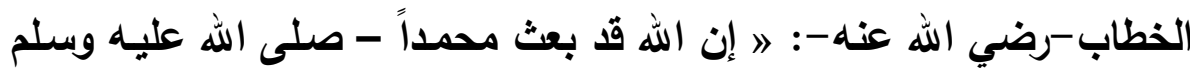

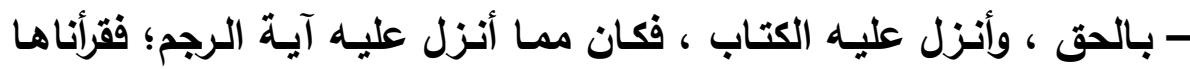

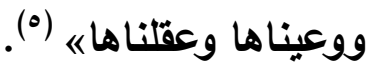

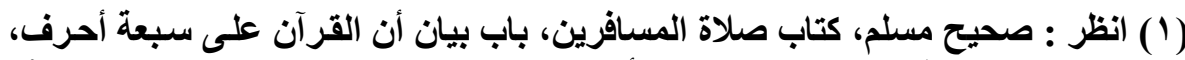

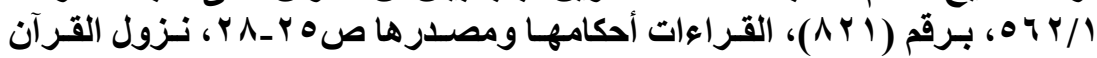

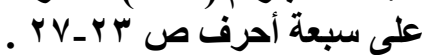

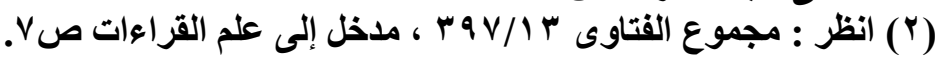

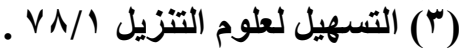

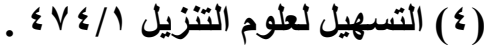

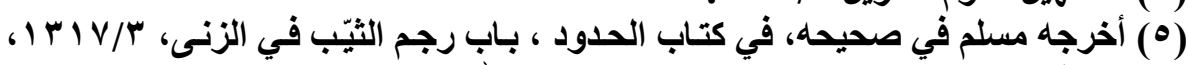
برقم (19 79 1)، من حديث أبن عباس- رضي الله عنهما . 
ويلخل تحت هذه القاعدة القواعد التالية : القاعدة الفرعية الأولى : أن آيات القرآن التي نزلت؛ منها فاعها ما بقيت تلاوتهه، ومنها ما نسخت تلاوته في زمن الوحي .

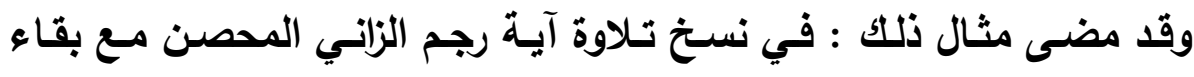

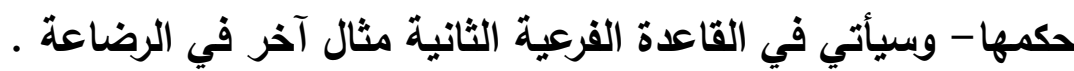

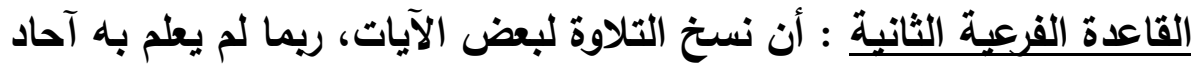
الصحابة إلا بعد فترة . ومن ذلك: قول عائشة-رضي الله عنها-: „اكان فيما أنزل من القرآن عثر رضعات معلومات

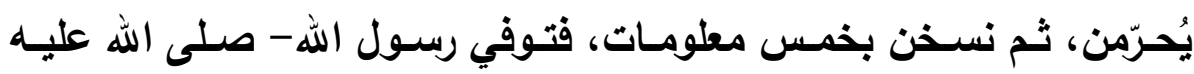

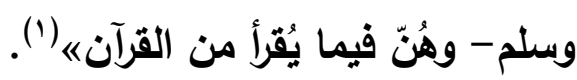

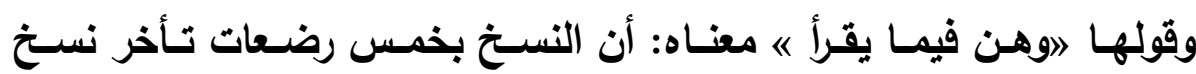

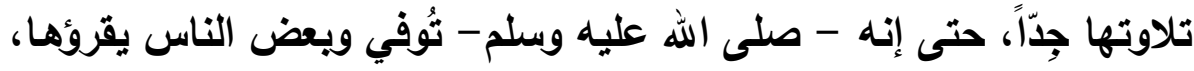

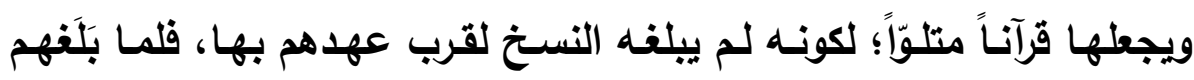

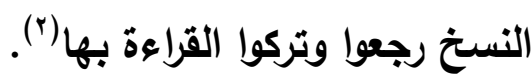

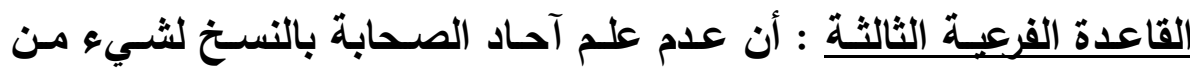

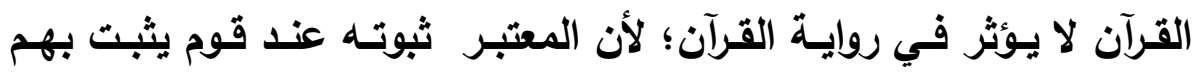

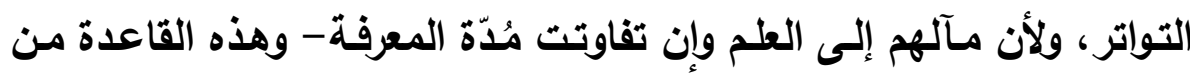
ثمرة القاعدة الفرعية الثانية(؟).

(1) الحديث : أخرجه مسلم في صحيحه، في كتاب الرضاع، باب التحريم بخمس رضعات،

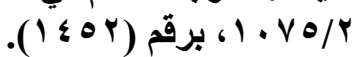

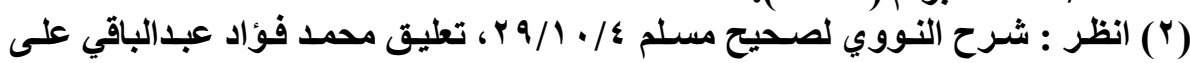

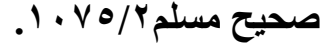

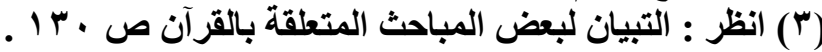


القاعدة الفرعية الرايعة : أن الصحابي الذي يكتب الوحي، ويتابع تلقي القرآن

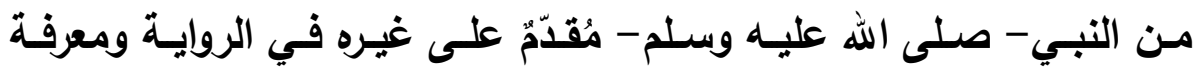

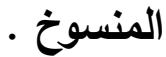

ويدل على هذه القاعدة : اختيار أبي بكر الصديق لزيل بن ثابت- رضي الله

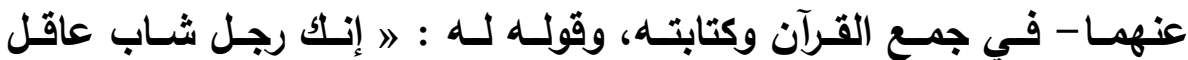
لانتهمك، وقد كنت تكتب الوحي لرسول الله-صلى الله عليه وسلم- فتتبع

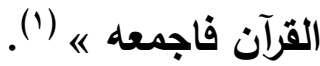

كما أنه ممن كتب المصاحف في زمن عثمان بن عفان - رضي الله عنهما(؟). القاعدة الرابعة : أن القرآن كلام الله لفظاً ومعنى. ومما يال على ذلك :

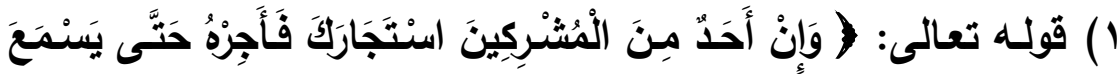

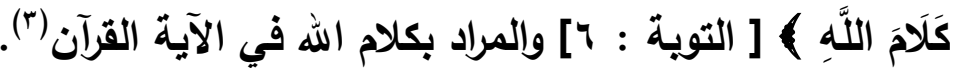

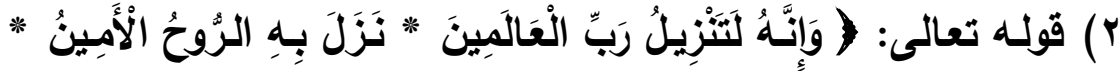

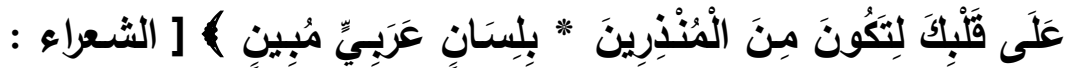
. [190-194

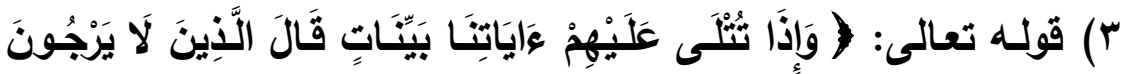

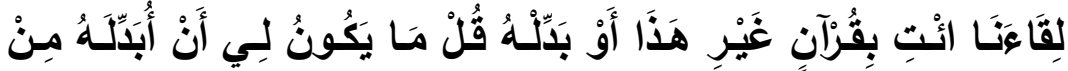

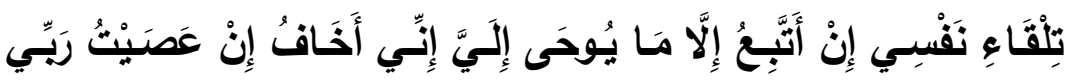

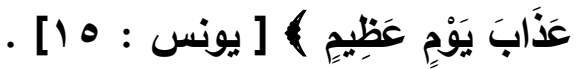

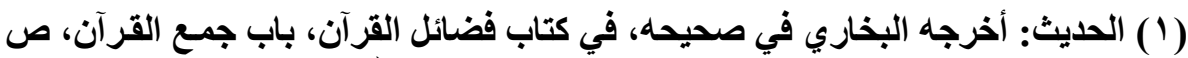

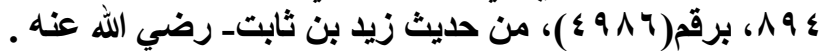

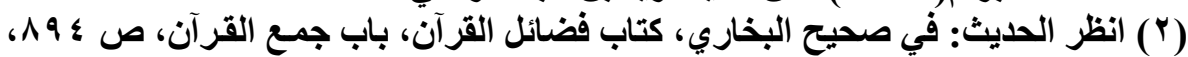


فهذه الآيـات وغيرهـا واضحة الدالـة على أن القرآن كـلام الله لفظـاً

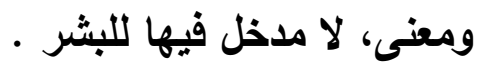

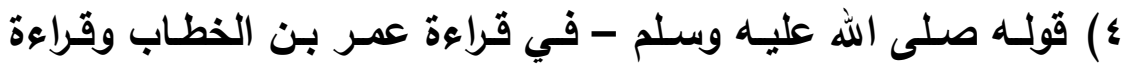

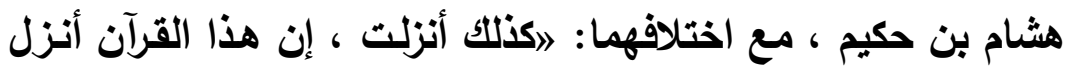

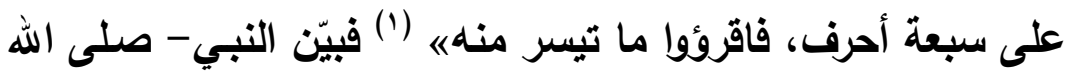

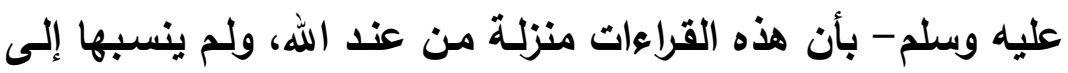
نفسه. قال ابن تيمية: " فإن أصحاب رسول الله- صلى الله عليه وسلم- تلقّوا

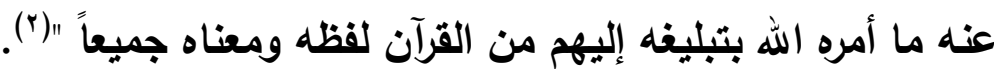
ومما ياخل تحت هذه القاعدة القواعد التالية :

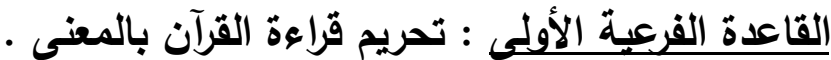

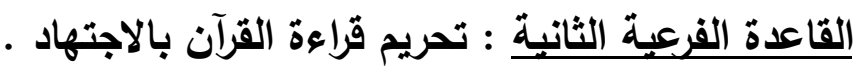
لأن القرآن كلام الله لفظاً ومعنى ، يجب نقله وروايته بلفظه ومعناه . المبحث الثاني: القواعد في حفظ القرآن .

سأذكر في هذا المبحث جملة من القواعد المتعلقة بحفظ القرآن، والتي لها

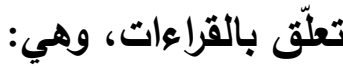
القاعدة الأولى:أن الله تكفل بحفظ القرآن، فلا يدخله التغيير والتبديل. وحفظ الله للقرآن : يثمل حفظه التام من الزيادة والنقص والتغييز والتبديل والتحريف .

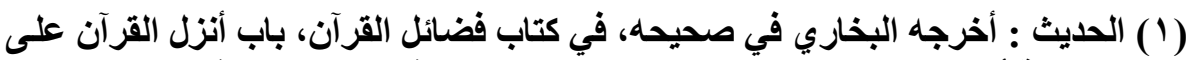

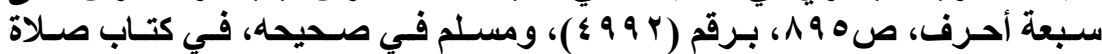

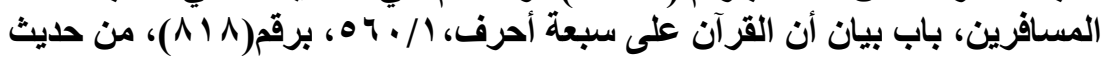

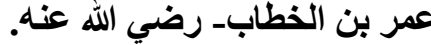

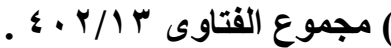


ويشمل حفظه في الصدور عن طريق التلقي والروايـة، وحفظه في السطور

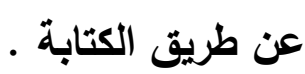

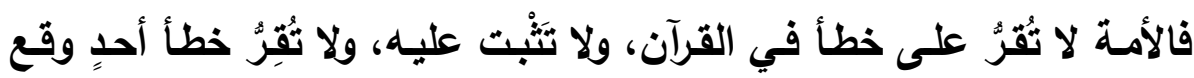
فيه.

ولا ينافي هذا وقوع أخطاء من آحاد الناس فيه؛ لأن الخطأ يَرِدِ على النفس

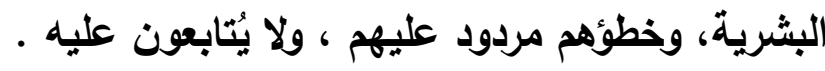
ومما يدل على حفظ الله للقزآن :

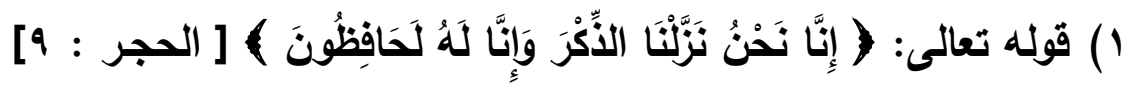

قال السعدي: " ( إنا له لحافظون) ؛ أي : في حال إنزالهه ويعد إنزاله، ففي حال إنزاله حافظون له من استراق كل شيطان رجيم، ويعد إنزالهـ أودعه الله

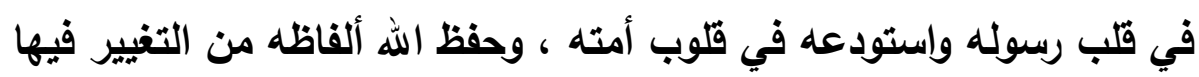
والزيادة وإلنقص، ومعانيه من التبديل"( (1).

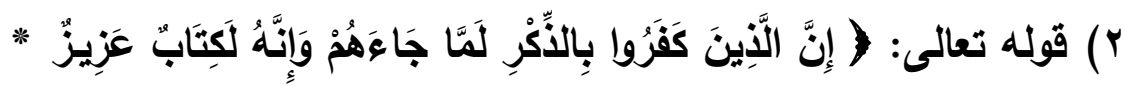

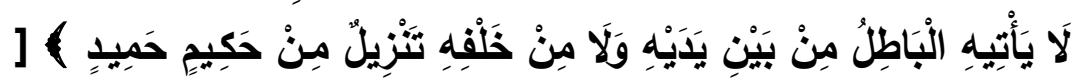

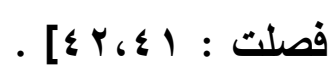

قال السعدي :" أي: لا يَقْريه شيطان من شياطين الإنس والجن لا بسرقة ولا

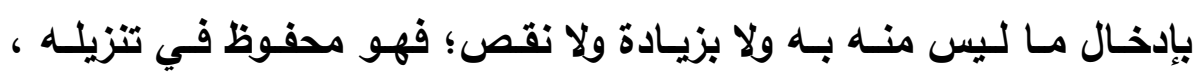
محفوظة ألفاظه ومعانيه، قـ تكفل من أنزله بحفظه" (؟).

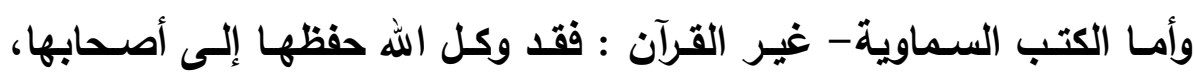

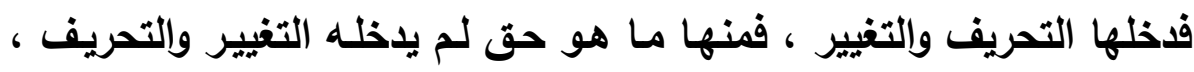




\section{ومنها ما هو باطل بسبب التغيير والتحريف(').}

القاعدة الثانيـة : أن الصـحابة أجمعوا على هذا القرآن مـن غير زيـادة ولا

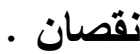
فمن منهج الصحابة: الحرص على تلقي القرآن وحفظه من الزيادة وإلنق،

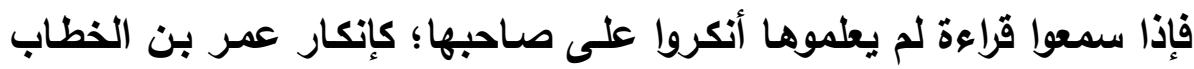
لقراعة هشام بن حكيم ، وأُبيّ بن كعب لغيره (؟).

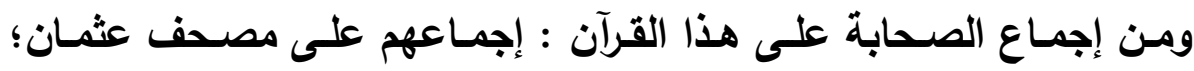

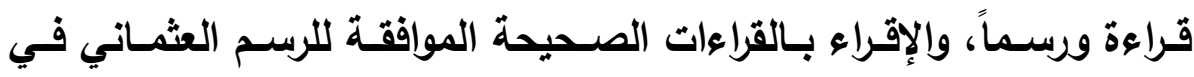

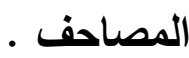
ولا يوجد في الرسم العثماني خطأ أو لحن أو زيادة أو نقصان تخالف القرآن؛ لأب

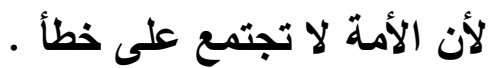

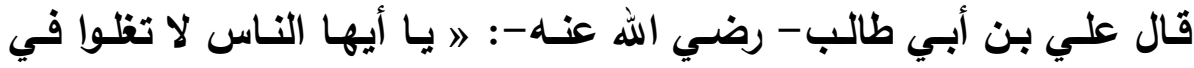

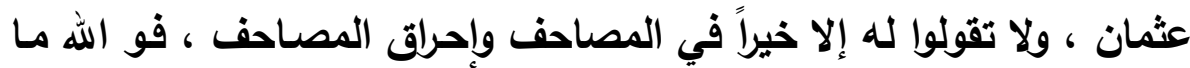

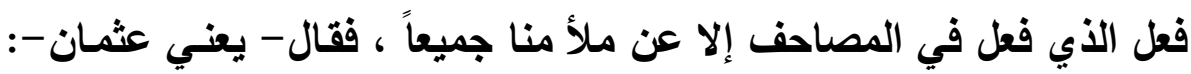

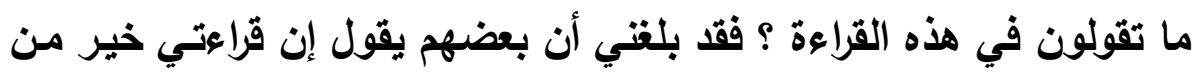

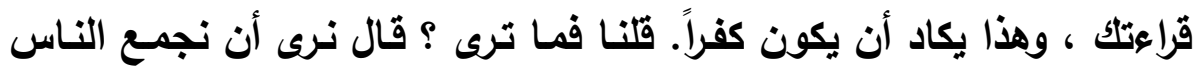

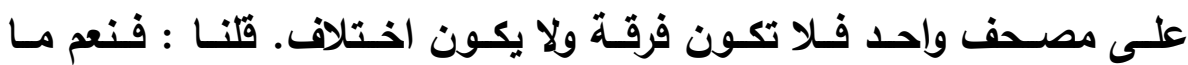

$$
\text { رأيته }
$$

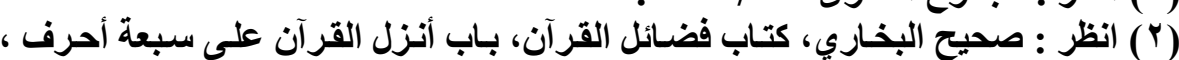

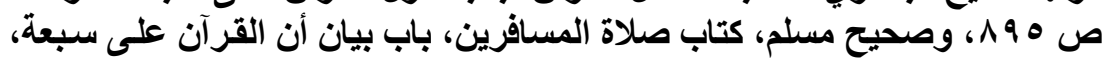

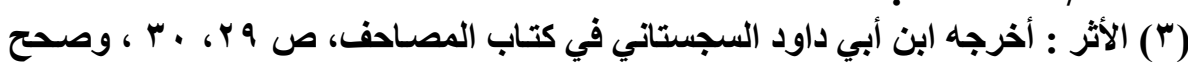

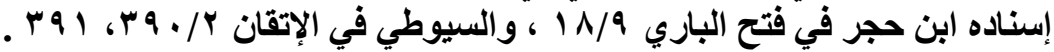


وقال الطوفي: " لا نزاع بين المسلمين في تواتر القرآن "(1).

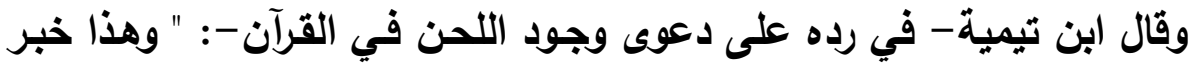
باطل لا يصح من وجوه، أحدهما : أن الصحابة- رضي الله عنهم- كـانوا

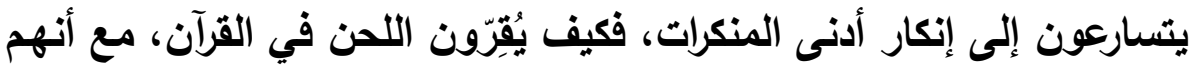

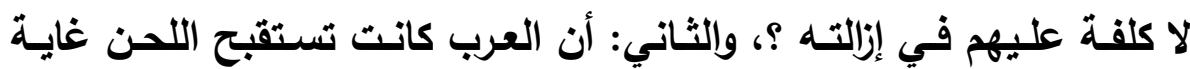

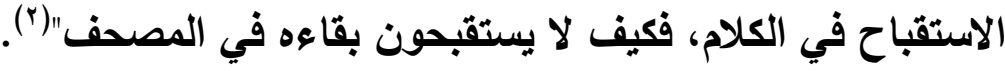
وقال أيضاً : " فإن أصحاب رسول الله - صلى الله عليه وسلم - تلقّّوا عنهـ ما أمره الله بتبليغه إليهم من القرآن لفظه ومعناه جميعاً "("(").

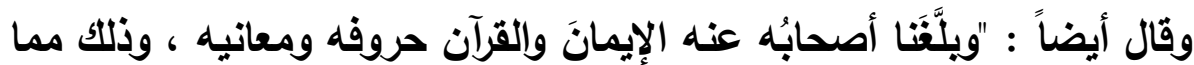

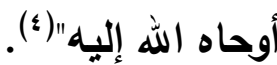
ويدخل تحت هذه القاعدة القواعد التالية: القاعدة الفرعية الأولى: لم يصح استمرار أحد من الصحابة في إنكار شيء

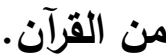
ودليل هذه القاعدة : إجماع الصحابة على مصحف عثمان من غير زيادة ولا

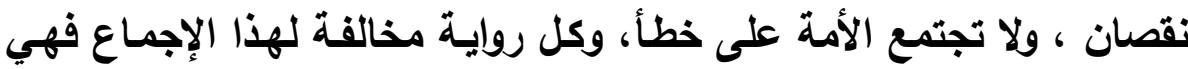

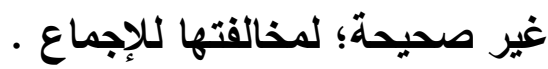
القاعدة الفرعية الثانية: أن ما رُوي عن آحاد الصحابة في إنكار شيء من لن

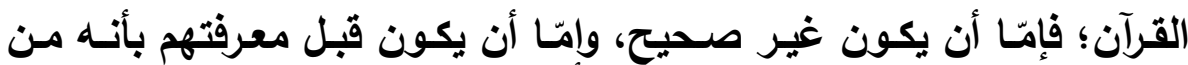
القرآن أو القراءات، أو تُحمل على تخريجات أخرى لا تتضمن الإنكار . ودليل هذه القاعدة: دليل القاعدة الفرعية الأولى السابقة.

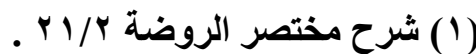

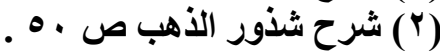

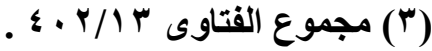

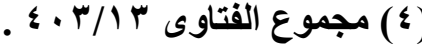


ومن الأمثلة على ذلك: ما رُوي عن ابن مسعود - رضي الله عنه- من إنكاره

للمعوذتين (1)

فجميع الآثار الواردة عن ابن مسعود ضعيفة، لا يصـح منها شـيء؛ لأنها

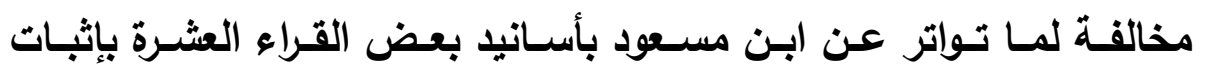
المعوذنتين من القرآن.

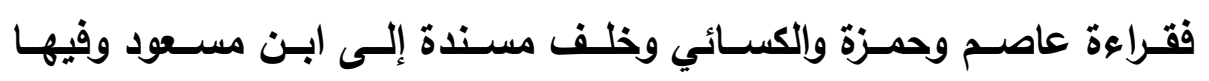

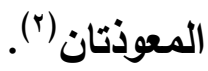

قال النووي: " أجمع المسلمون على أن المعوذتين والفاتحة وسـائر السور

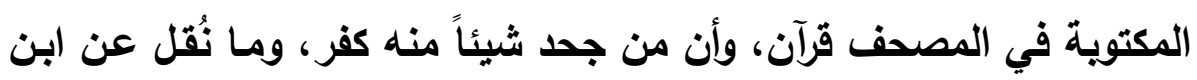

مسعود في الفاتحة والمعوذتين باطل ليس بصحيح عنهة"(").

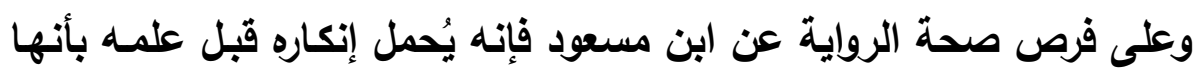

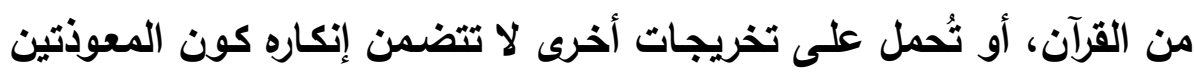

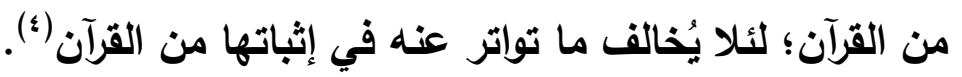

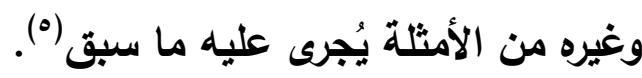

القاعدة الثالثة : أن القرآن متواتر قطعي الثبوت.

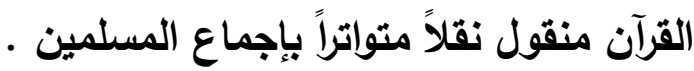

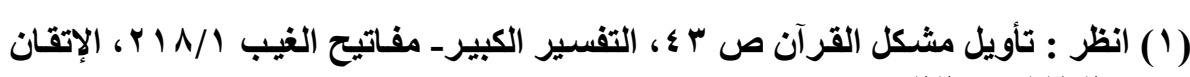
ا

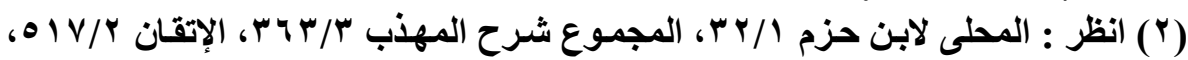

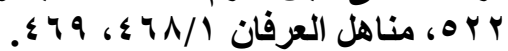

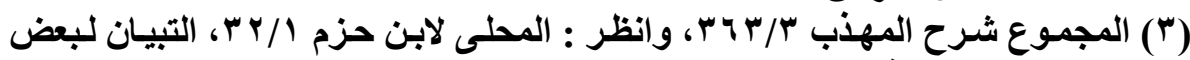

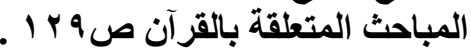

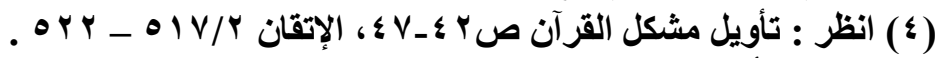

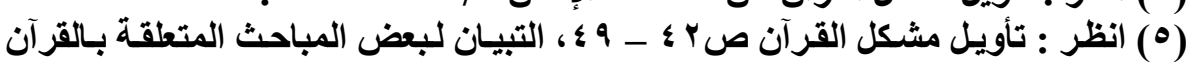

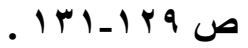


والمتواتر : هو ما رواه جمع عن جمع لا يمكن تواطؤهم على الكذب من أوّل الإسناد إلى آخره('). ويفيد هذا التواتر : العلم اليقيني، والقطع بصحته وثثبوته، فلا يتطرق إليه شك إلى

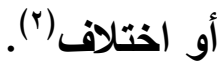
قال الطوفي: "لانزاع بين المسلمين في تواتر القرآن"("). ويدخل تحت هذه القاعدة القواعد التالية :

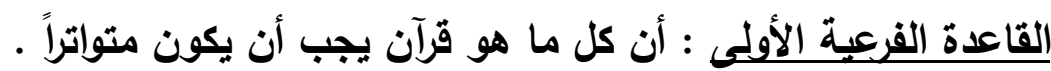

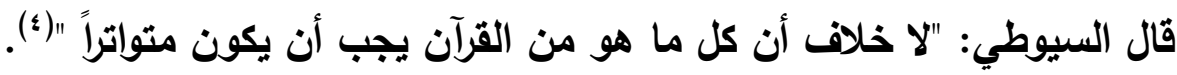

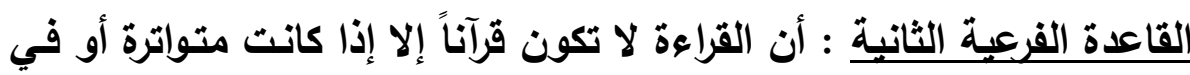

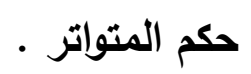
وذلك لأن التواتر شرط في القرآنية(ْ)، وعلى هذا؛ فكل قراءة ليست متواترة لا تأخذ حكم القرآن تلاوة واعثقاداً. القاعدة الفرعية الثالثة : أن القرآن لم يقع فيه اختادة الثلاف، وإنما وقع الخلاف

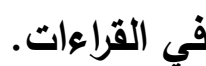
أي لم يقع خلاف البتة في ذات القرآن ، وإنما وقع في وجوه قراءاتهـ؛ لعدم

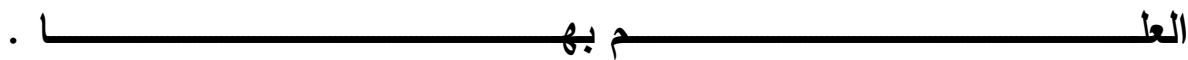

القاعدة الرابعة : أن الزيادة والنقصان في القرآن كفر.

(1) انظر : شـرح مختصـر الروضـة / V V ، ؛ V، تــريب الـراوي ص 109 ، قواعد

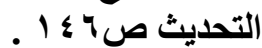

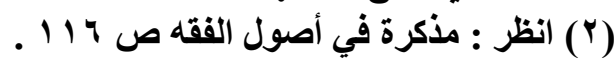

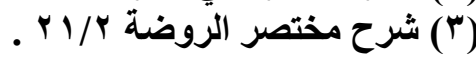

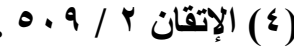

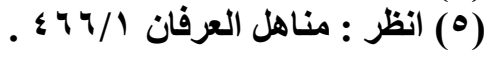


فمن زاد في القرآن أو نقص منـه حرفاً عمداً فقد كفر ؛ لأنهه مـن تحريف

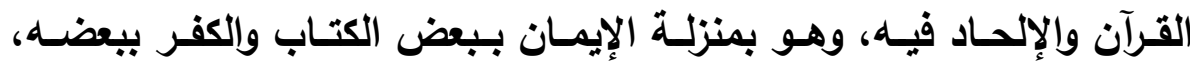

والقرآن مما علم من الاين بالضرورة (').

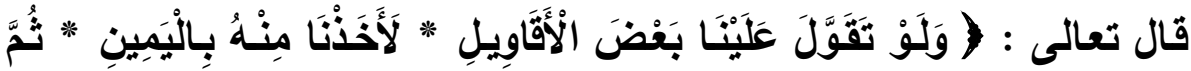

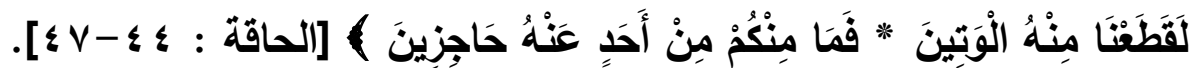
قال عبد الله بن مسعود - رضي الله عنه-: اهن كفر بحرف من القرآن فقد

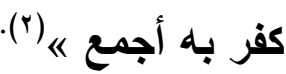

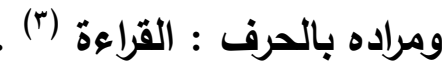

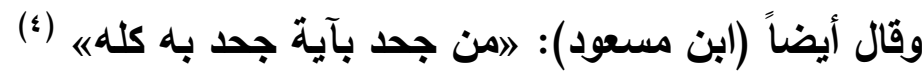

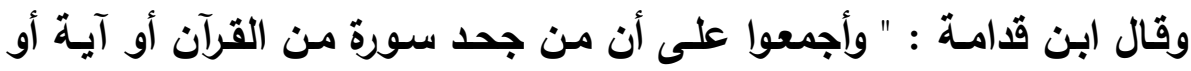

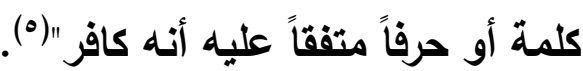
وقال ابن الجزري : "الإجماع منعقد على أن من زاد حركة أو حرفاً في القرآن

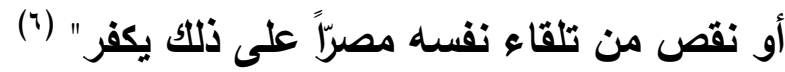
وهذا يدل على حفظ الله للقرآن . ويدخل تحت هذه القاعدة القواعد التالية :

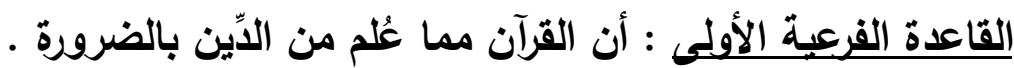

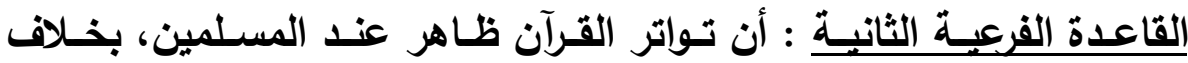
القراءات فقا يخفى أمر تواترها؛ لأنها إنما تواترت عند القراء الذين عُنوا بأمر التران

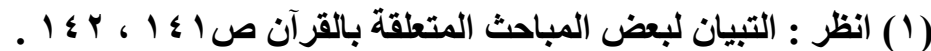

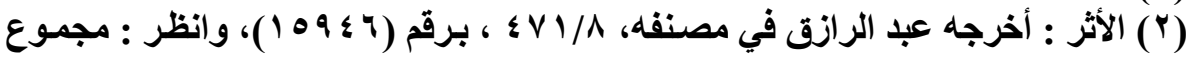

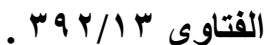

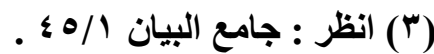

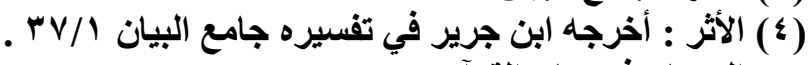

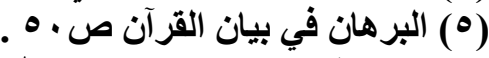

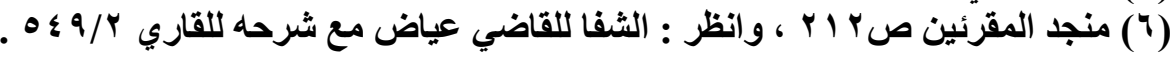


القراءات وضبط وجوهها دون غيرهم- هذا من حيث مجموعها، وإمـا إفرادها فكل قوم غُنوا بقراء معينة فتواترها ظاهر عندهم .

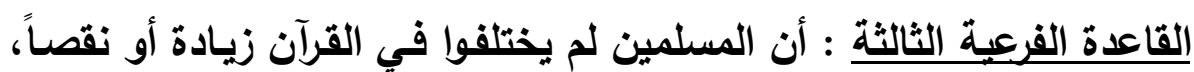

وإنما اختلفوا في وجوه القراءات؛ لأنها مما يخفى على البعض (1).

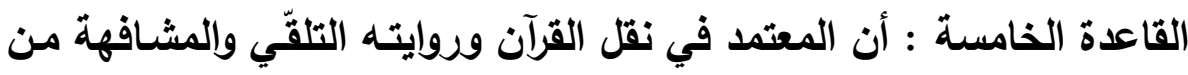
الأئمة الثقات بعضهم عن بعض، وأما المصحف فهو مساند للحفظ والرواية .

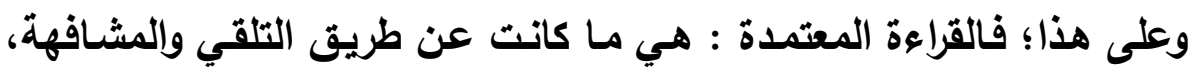

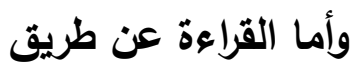

المصحف من غير تلقي ولا مشافهة؛ فهي قراءة غير معتمدة .

$$
\text { ومما يال على ذلك: }
$$

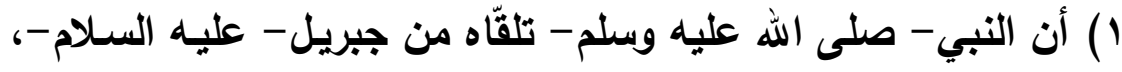

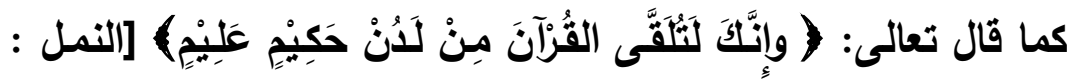

وكان جبريل يعارضه القرآن في رمضان من كل عام(†).

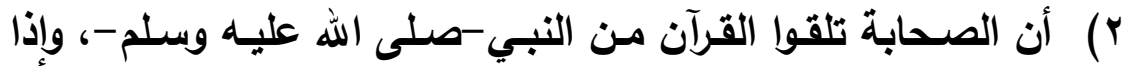

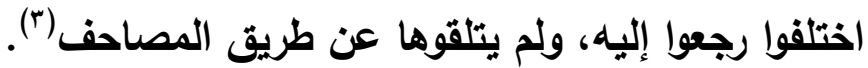

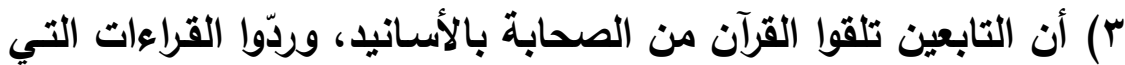

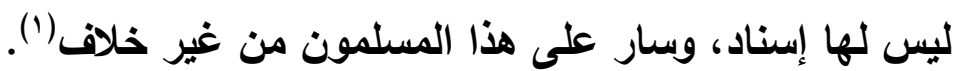

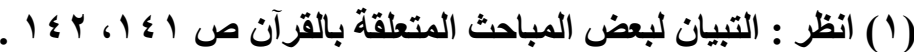

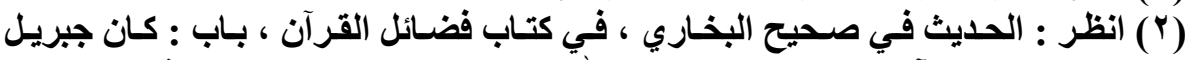

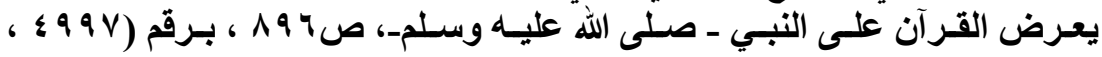
( ( $199 \wedge$

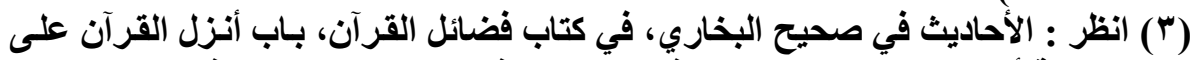

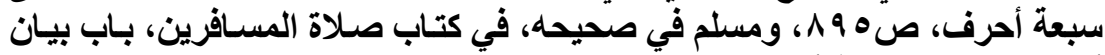

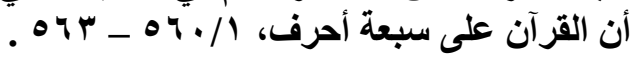


ع) قال زيد بن ثابت-رضي الله عنه-: 》 القراعة سنة «(؟).

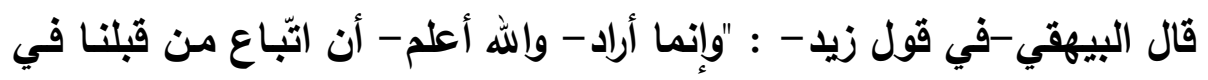

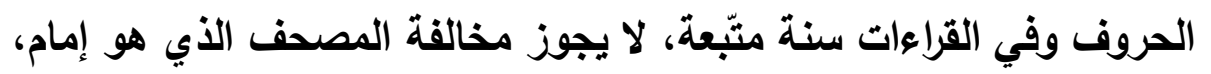
ولا مخالفة القراءات التي هي مشهورة"(").

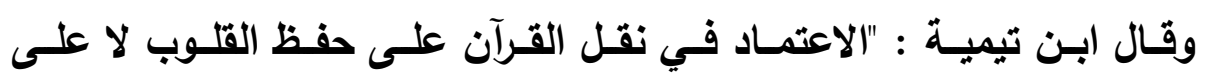

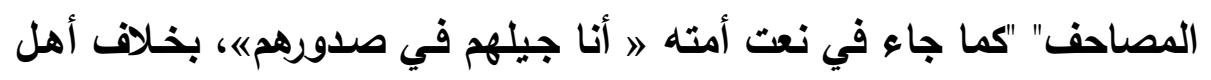

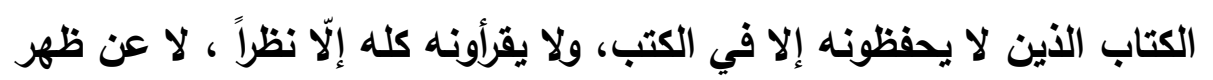

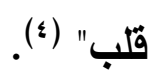

قال القسطلاني : "علم الإسناد: وهو أعظم مدارات هذا الفن؛ لأن القراءات

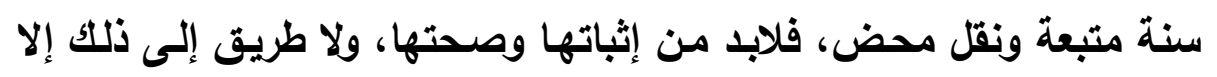

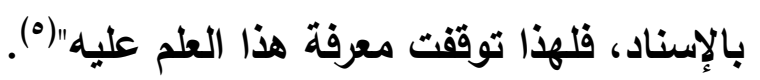
ويلخل تحت هذه القاعدة القواعد التالية :

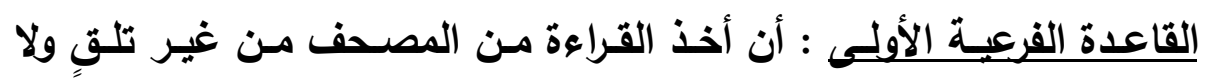

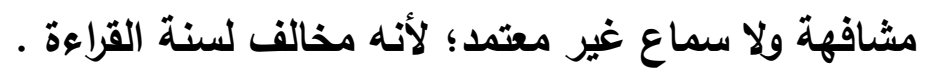

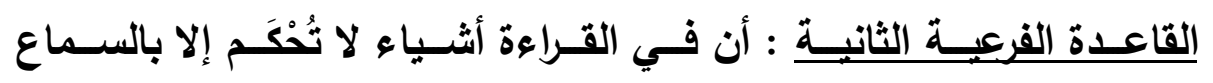
والمشافهة في أدائها .

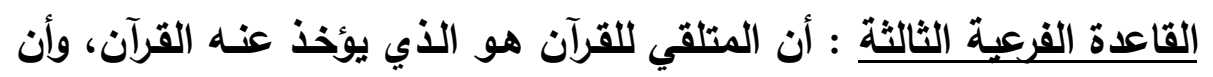
غير المتلقي للقرآن لا يؤخذ عنه القرآن .

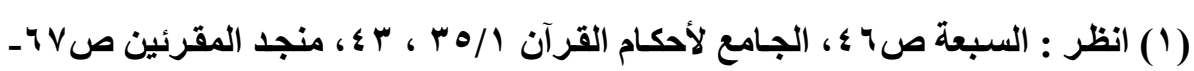
1. 1. VY

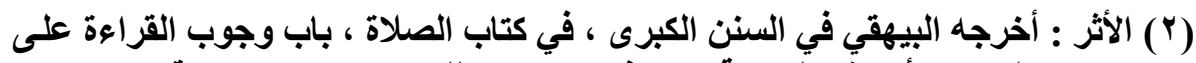

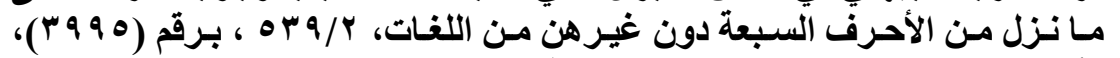

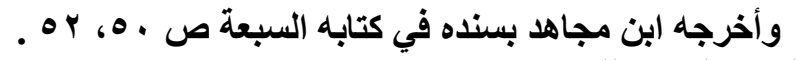

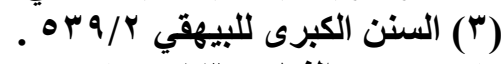

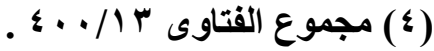

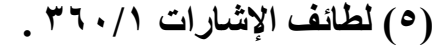




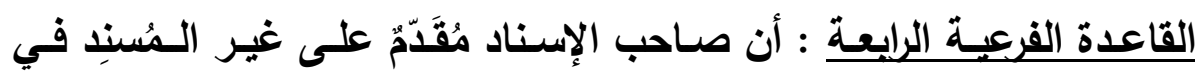
القراءة أو الاختلاف فيها. القاعدة الفرعية الخامسـة : أن من أسباب الخطأ في تلاوة القرآن أخذه من الخداف المصحف من غير تلثِ ولا سماع، أو أخذه من غير أهله المقرئين .

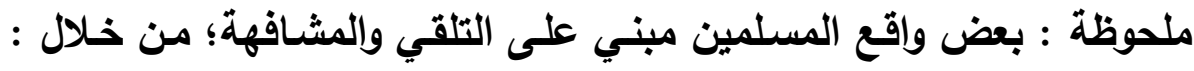

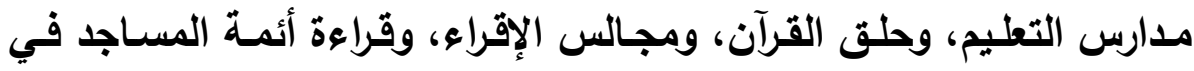

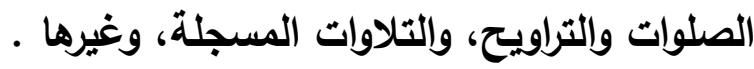

القاعدة السادسة : أن القرآن يَتبَت بـأي حرف من الحروف السبعة، ويَتُبت بأي وجه من وجوه القراعات المتواترة . فالقرآن نزل على سبعة أحرف، وكل حرفٍ منها قرآن، فمن قرأ القرآن بأي حرفٍ منها فقد

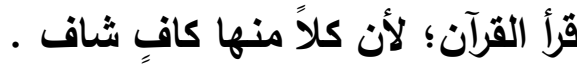

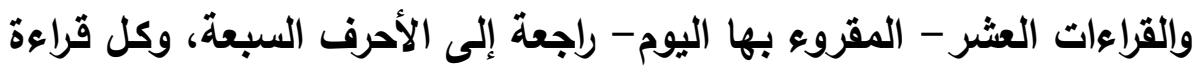

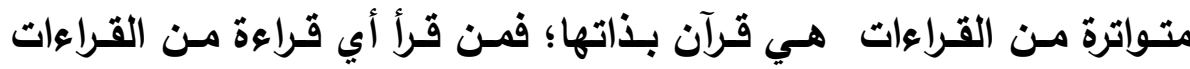
المتواترة فقد قرأ قرآناً . ومما يال على ذلك :

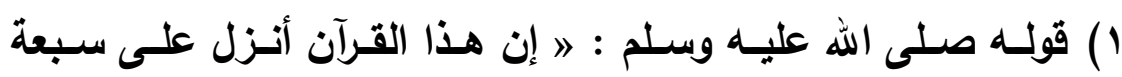
أحرف، فاقرؤوا ما تيسر منه «" (')

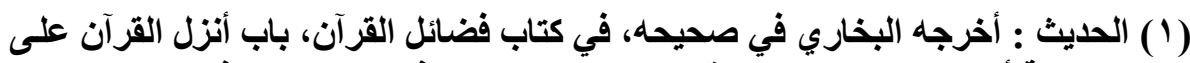

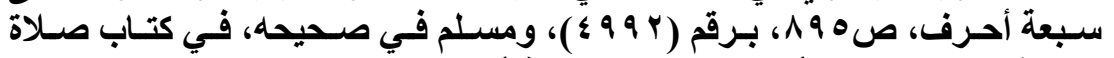

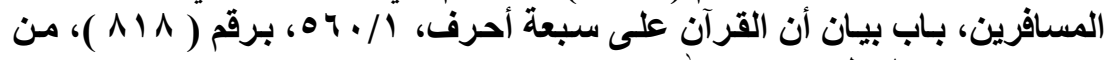

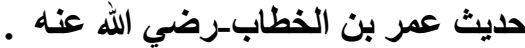




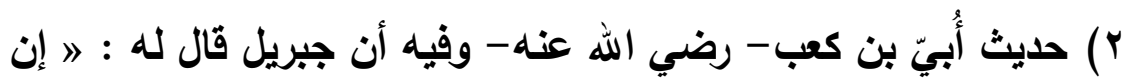

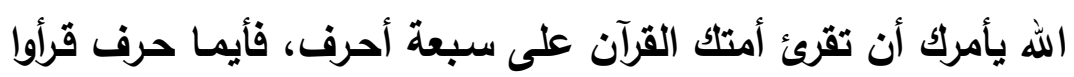

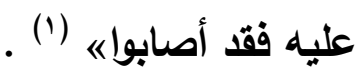

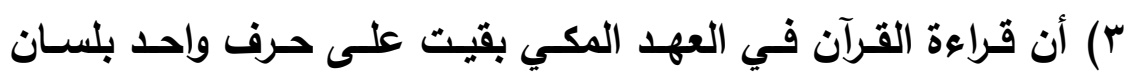

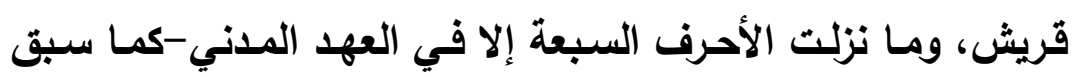
بيانه في القاعدة الثانية من قواعد نزول الاهرف القرآن. ويلخل تحت هذه القاعدة القواعد التالية:

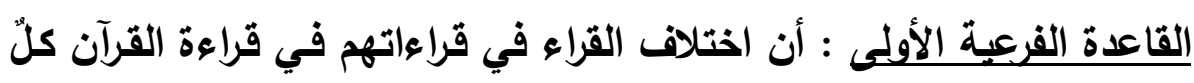
منها قرآن، كما أن اتفاقهم في قراءاتهم المتواترة للقرآن يُعَّد قرآناً.

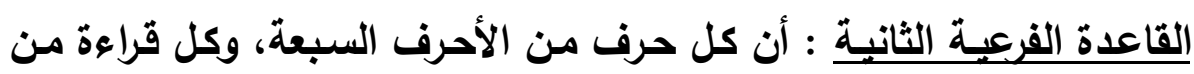

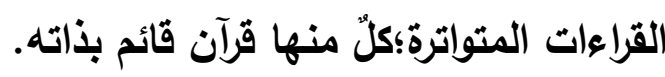

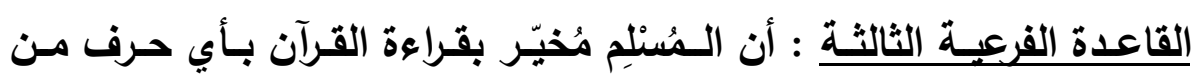

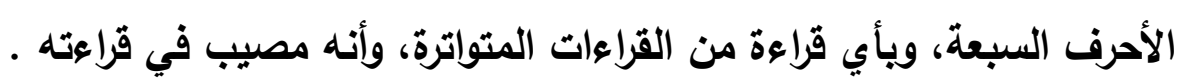

(1) الحليث : أخرجه مسلم في صحيحه، في كتاب صلاة المسافرين، باب بيان أن القرآن

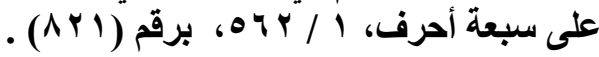




\section{الفصل الثاني: القواعد في نزول القراءات وحفظها.}

المبحث الأول: القواعد في نزول القراءات.

سبق الحديث في الفصل الأول عن القواعد في نزول القرآن وحفظه، ونظراً

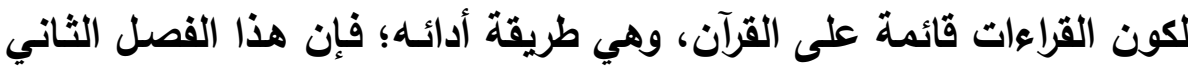

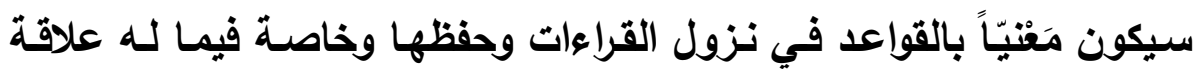

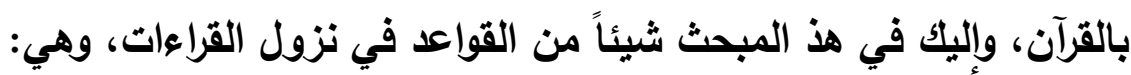

القاعدة الأولى : أن الأحرف السبعة منزلــة من عند الله، كمـا أن القراعات

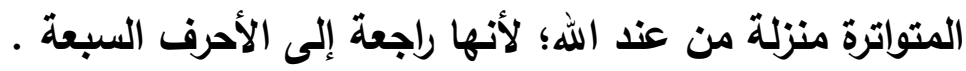
ومما يدل على ذلك :

1) قولـه صلى الله عليه وسـلم - في قراءة عمـر بن الخطاب وقراءة

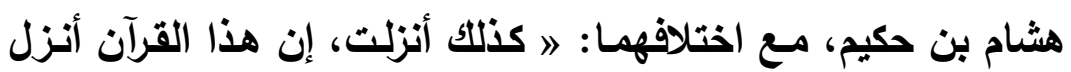

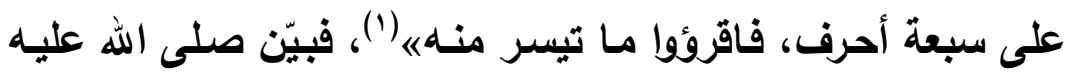
وسلم بأن هذه القراءات منزلة من عند الله ، ولم ينسبها إلى نفسه.

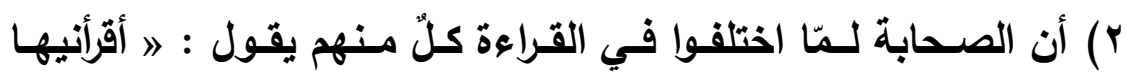

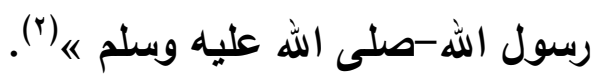

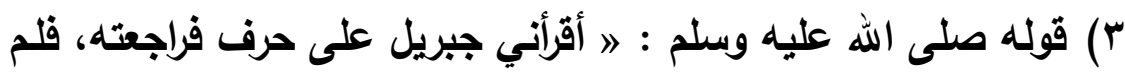

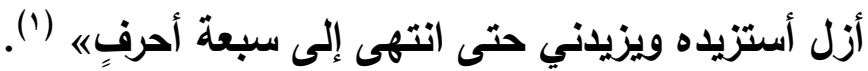

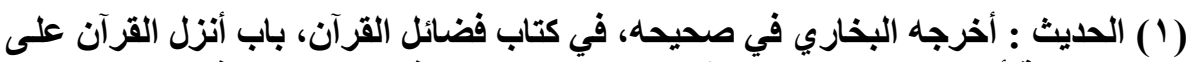

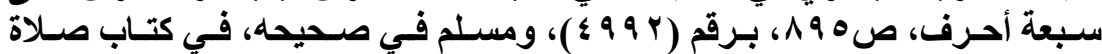

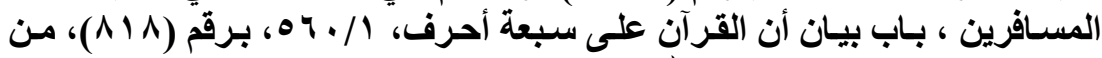

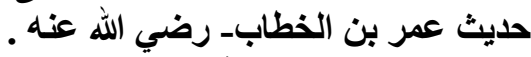
الحايث : سبق تخريجه في الحديث السابق قبله . 
والأدلة على هذه القاعدة كثيرة (). قال الزرقاني: " أجمعت الأمة على أنه لا مدخل للبشر في نظم هذا لألها القرآن، لا

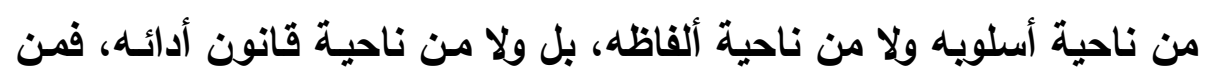

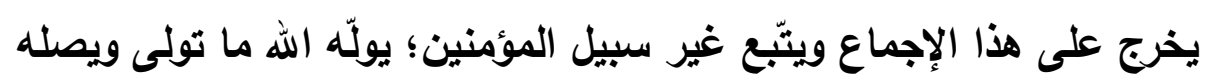
جهنم وساءت مصيراً "("). وقـال أيضاً : " لو صـح لأحدٍ أن يغيّر مـا شـاء من القرآن بمرادفهـ أو غير

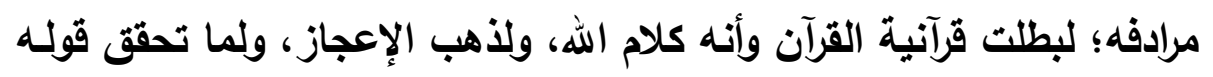

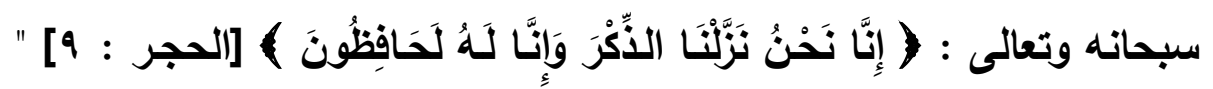

ويلخل تحت هذه القاعدة القواعد التالية :

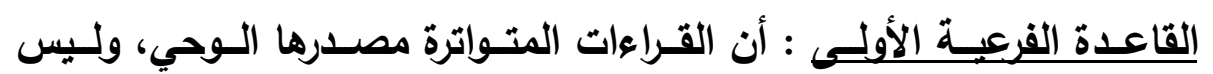

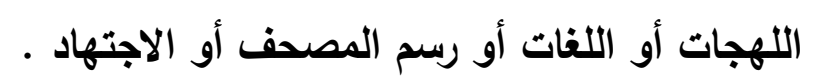

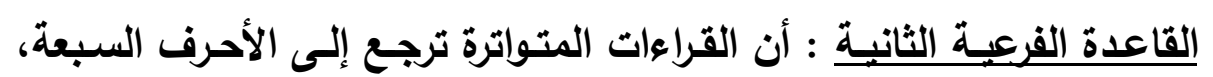

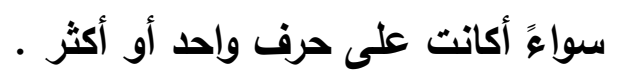

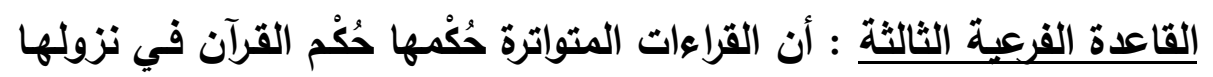

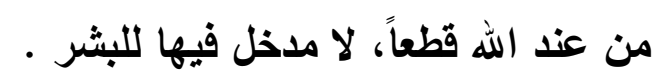

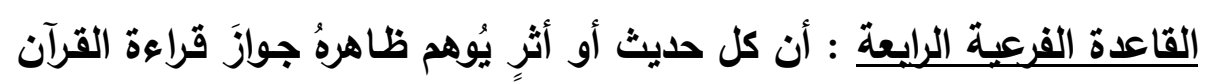

\footnotetext{
(1) (الحديث : أخرجه البخاري في صحيحه، في كتاب فضائل القرآن، باب أنزل القرآن على فئي

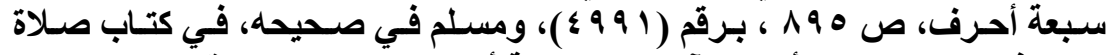

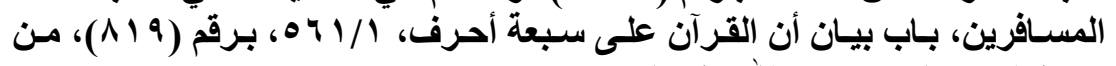

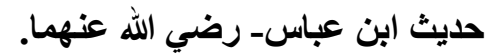

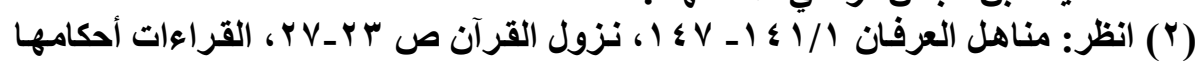

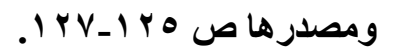

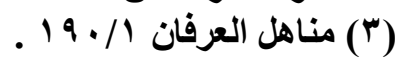

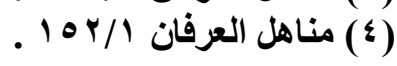


بالاجتهاد فهو مردود؛ فإمَا أن يكون غير صحيح، وإمتَا أن يكون ظاهره غير

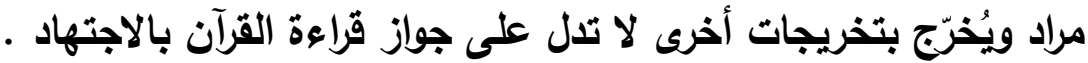

القاعدة الثانية: أن الأحرف السبعة قرأ بها النبي-صلى الله عليه وسلم-، النهات

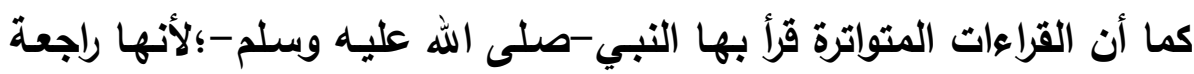

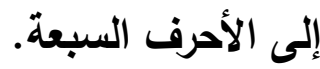

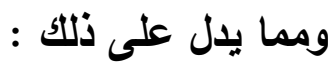

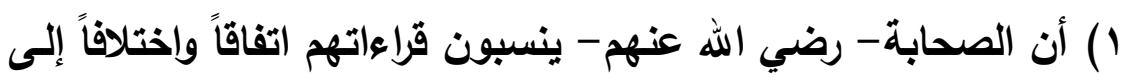

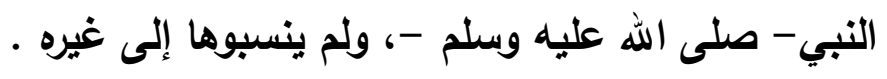

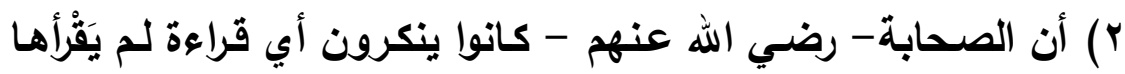

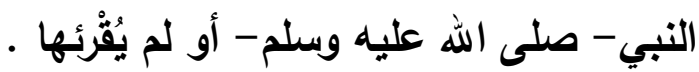
r) أن الصحابة كانوا يرجعون عند الاختلاف في القراءة إلى التبي-صلى الفى

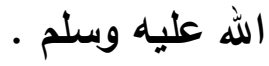
ومن الأحاديث في ذلك : أ - حليث عمر بن الخطاب- رضي الله عنه- قال: " سمعت هثام بن حكيم

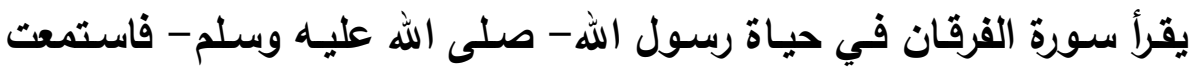

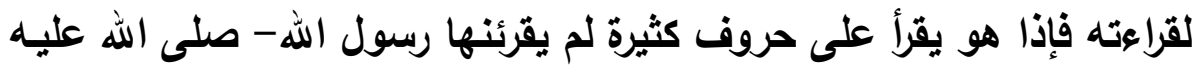

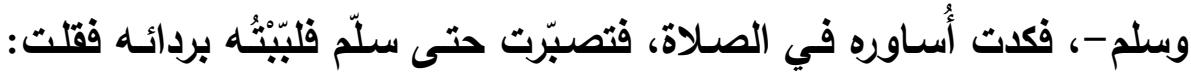

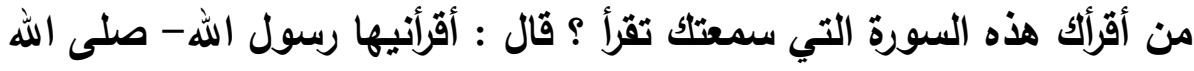

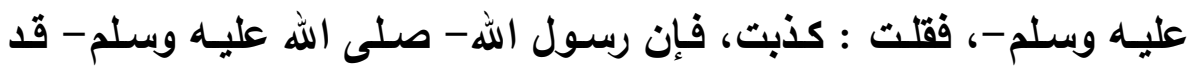
أقرأنيها على غير ما قرأت، فانطلقت به أقودُه إلى رسول الله - صلى الهي الله عليه

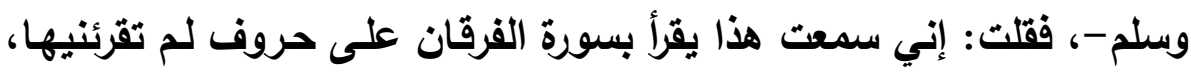
فقال رسول الله- صلى الله عليه وسلم-: أرسله، اقرأ يا هثام، فقرأ عليه 
القراءة التي سمعته يقرأ، فقال رسول الله -صلى الله عليه وسلم- : كذلك

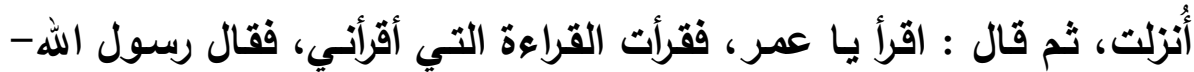

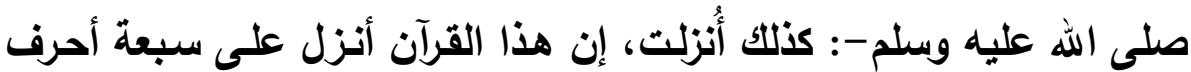

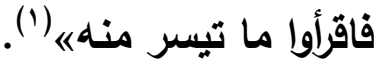

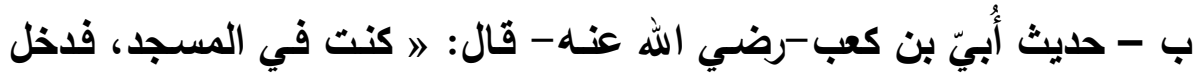

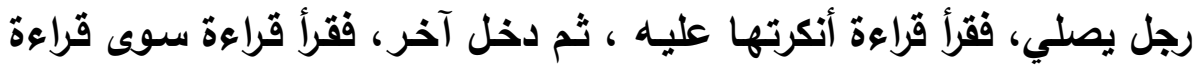

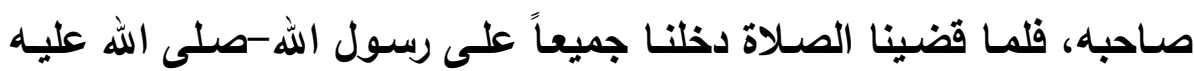

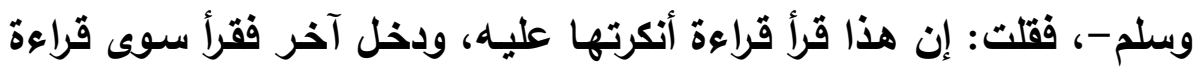

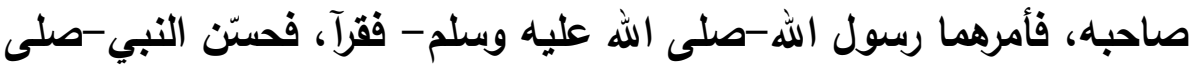

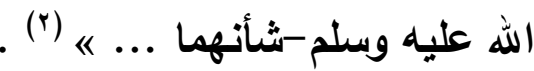
جـ - حديث عبد الله بن مسعود -رضي الله عنـه- قال: 》 سمعت رجلاً قرأ

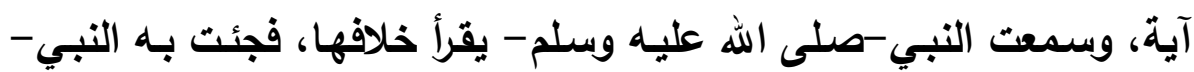

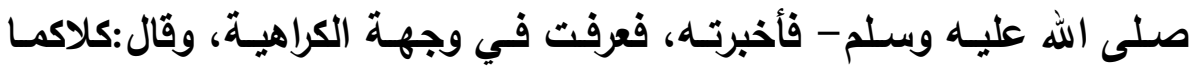

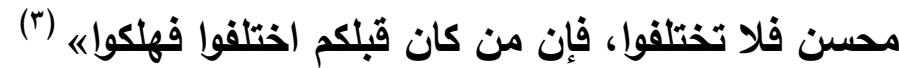
ويدخل تحت هذه القاعدة القواعد التالية : القاعدة الفرعية الأولى: أن القراءات المتواترة قرأ بها النبي - صلى الله عليه

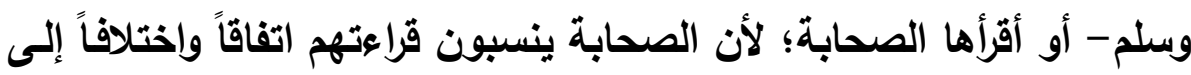
النبي- صلى الله عليه وسلم • النمان

(1) الحايث : أخرجه البخاري في صحيحه، في كتاب فضائل القرآن، باب : أنزل القرآن

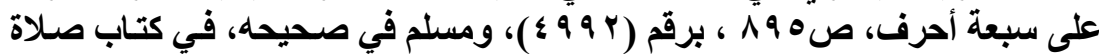

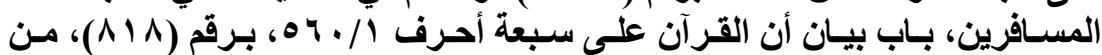

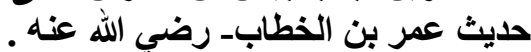

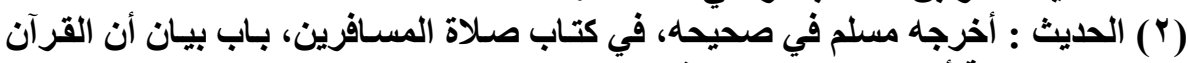

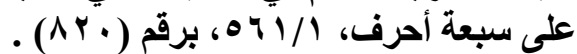

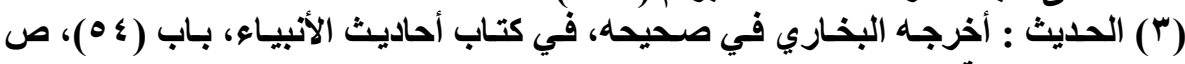

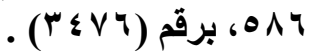


القاعدة الفرعيـة الثانبـة: أن أي قراعة لـم يَقْرأ بها النبي - صـلى الله عليه

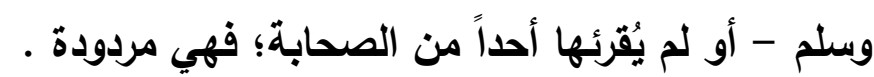

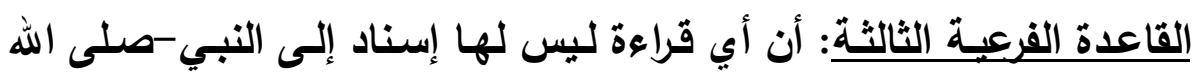

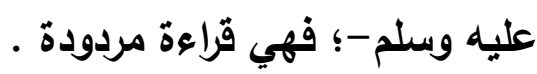

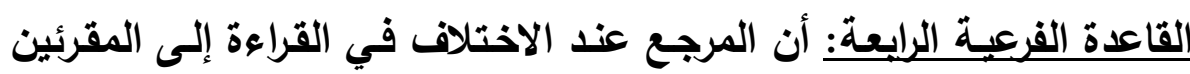
المُسندين (أصحاب الإسناد) إلى النبي -صلى الله عليه وسلم .

القاعدة الثالثة: أن الصحابة تلقّا الأحرف السبعة عن النبي -صلى الله عليه

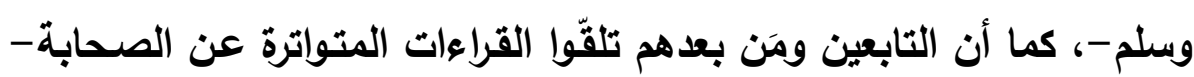

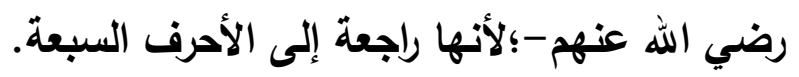
وتقرير ذلك : أن مـا يتعلق بتلقي الصحابة للأحرف السبعة عن النبـي- صلى الله عليه

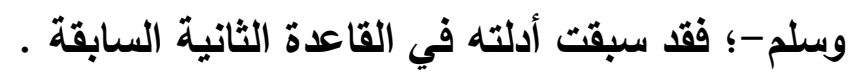

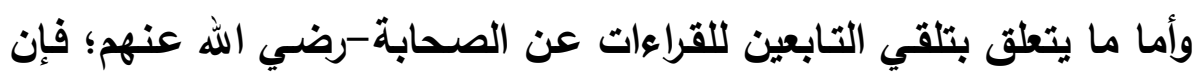

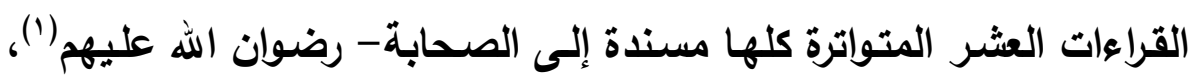
وما لم يكن مسنداً فهو مردود غير مقبول . ويدخل تحت هذه القاعدة القواعد التالية :

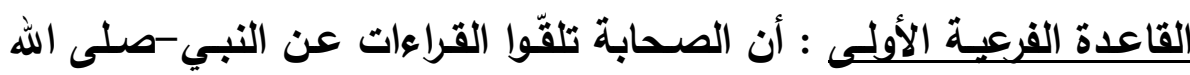

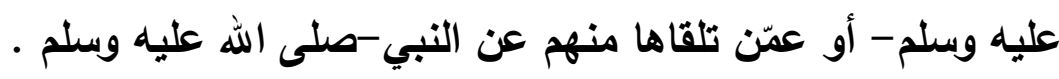

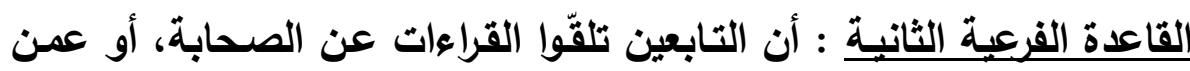

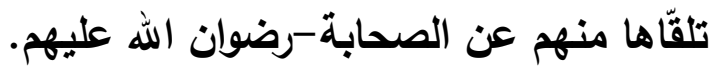

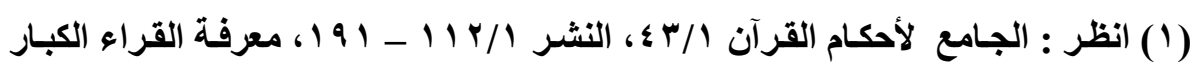

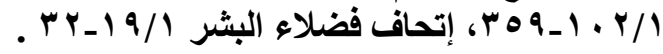




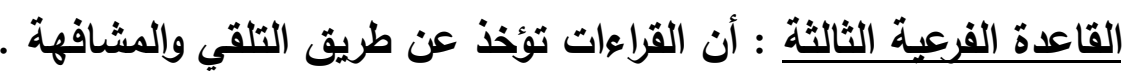

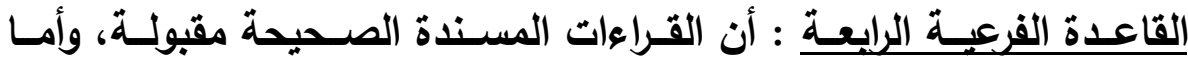
القراءات غير المسندة فهي مردودة . القاعدة الرابعة : أن من قرأ القزآن على حرف من الأحرف السبعة فقد أصاب

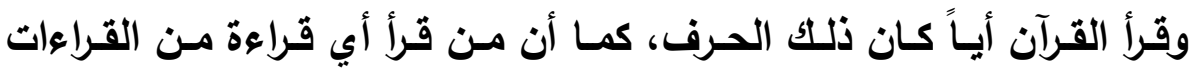

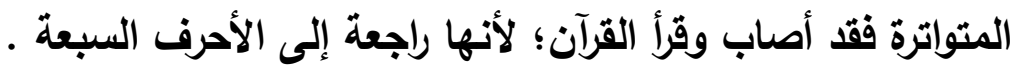
ومن الأدلة على ذلك :

1) حليث أُبيّ بن كعب-رضي الله عنه-: " أن النبي-صلى الله عليه

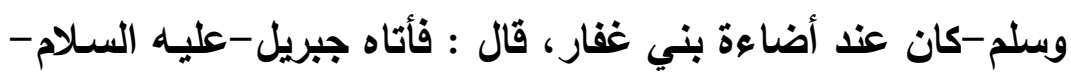

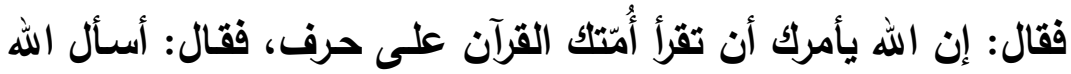

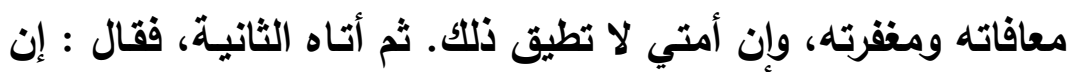

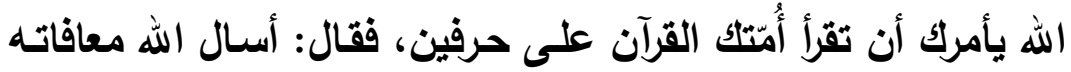

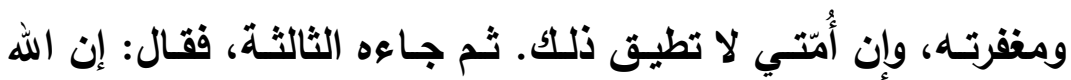

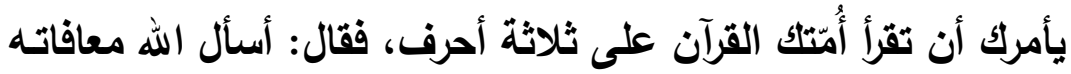

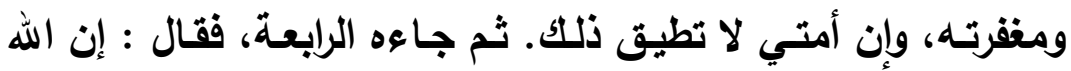

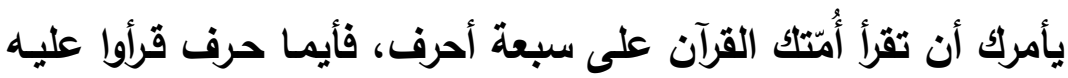

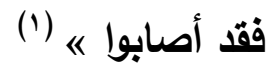

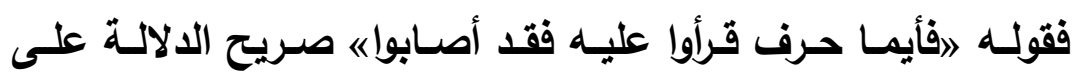

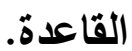

(') الحايث : أخرجه مسلم في صحيحه، في كتاب صلاة المسافرين، باب بيان أن القرآن آنران

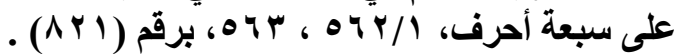


r) حديث عمر بن الخطاب واختلافهه في القراءة مـع هشام بن حكيم،

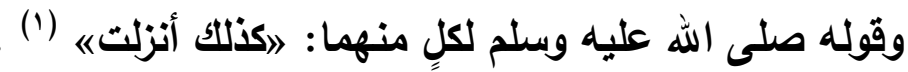

r) حليث عبد الله بن مسعود - رضي الله عذه-، قال: " سمعت رجلاً قرأ

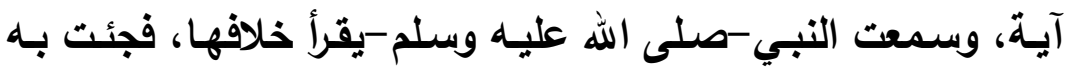

النبي-صلى الله عليه وسلم- فأخبرته، فعرفت في وجهة الكراهية،

وقال: كلاكما محسن فلا تختلفوا، فإن من كان قبلكم اختلفوا فهكواه

فكاها تدل على أن من قرأ على حرف من الأحرف السبعة فقد أصاب وقرأ القرآن،كما تلدل

على النهي عن منع أحد من القراءة بأي حرف من الأحرف السبعة النازبة(")

ويدخل تحت هذه القاعدة القواعد التالية :

القاعدة الفرعية الأولى : أن الأحرف السبعة كلها من عند الله، لا مدخل فيها

للبشر ، كما أن القراءات المتواترة منزلة من عند الله ، لا مدخل فيها للبشر.

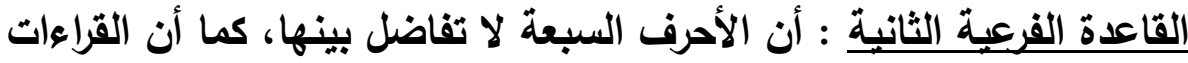

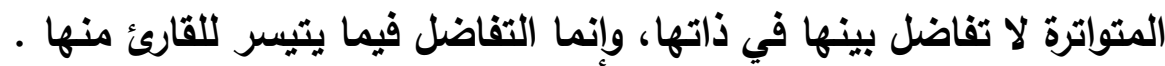

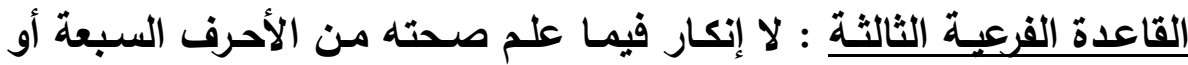

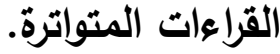

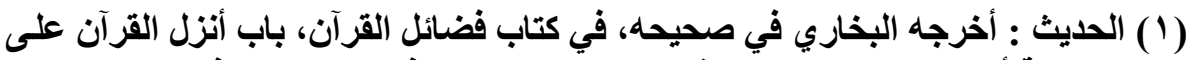

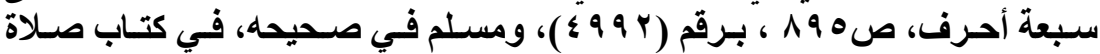

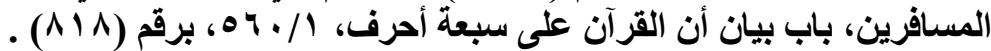

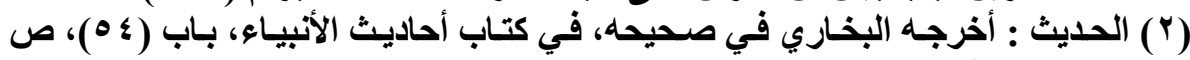

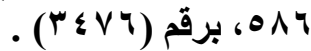

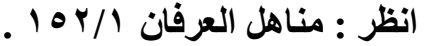


القاعدة الفرعية الرايعة : النهي عن الاختلاف والمنازعة في القراءة على أي حرف من الأحرف السبعة أو أي قراءة من القراءات المتواترة؛ لإباحة القراءة بها كلها . القاعدة الفرعية الخامسية : لا يُمنع أحد من القراءة بأي حرف من الأحرف

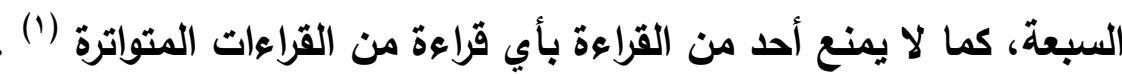

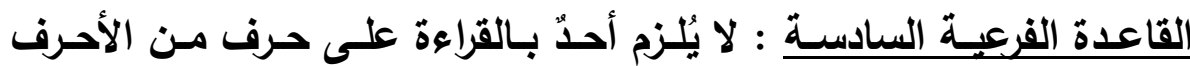

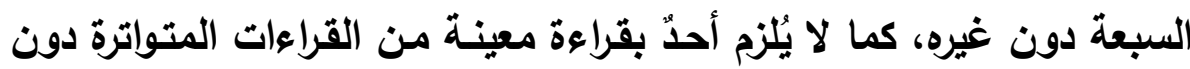

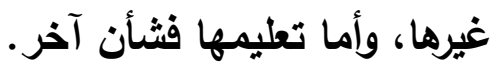


يُعرض في هذا المبحث مجموعة من القواعد في حفظ القراعات، والتي لها

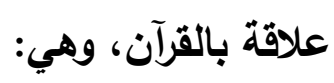

القاعدة الأولى: أن القراعة سُنّة مُتبّعة، يأخذها الآخِر عن الأوّل.

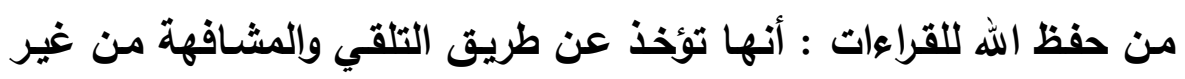

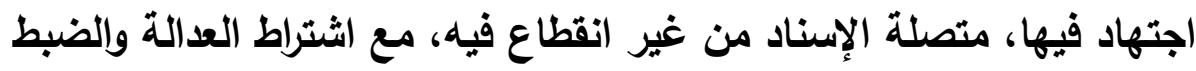
في رواة القراءة . وكل قراءة خالفت ذلك فهي مردودة .

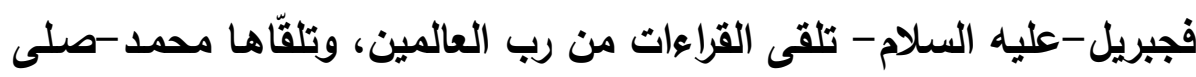

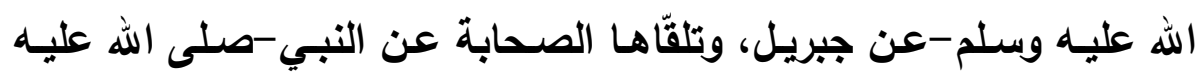

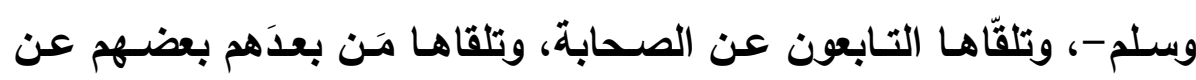
بعض، حتى وصلت إلينا بأسانيدها.

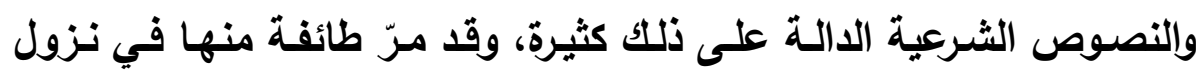

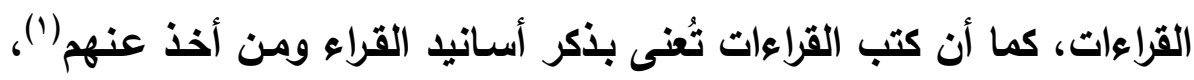
والإسناد قائم حتى اليوم .

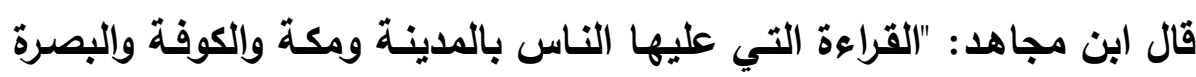

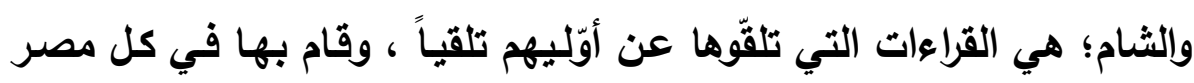

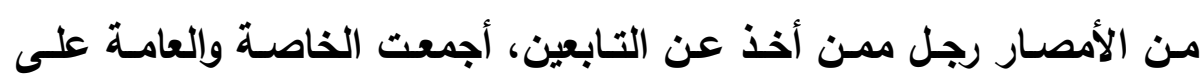

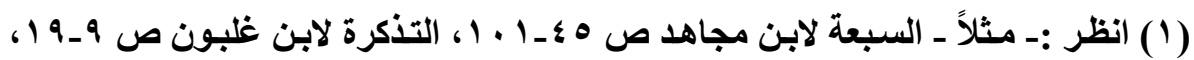

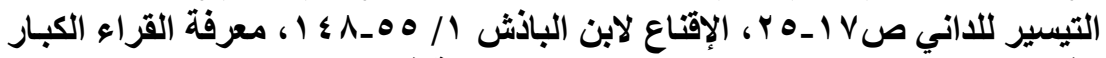

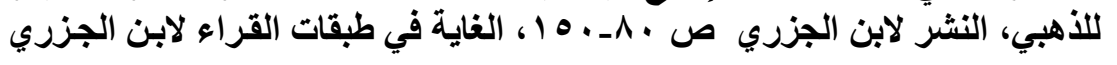




\section{قراعته، وسلكوا فيها طريقه وتمسكوا بمذهبه " (') .}

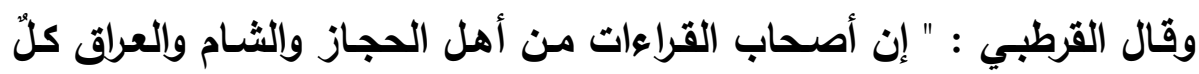

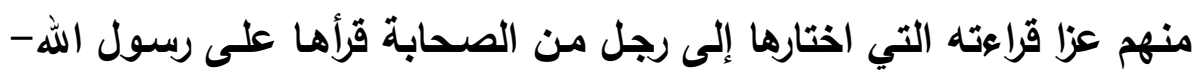
صلى الله عليه وسلم -ولم يستثن من جملة القرآن شيئاً ... " (؟).

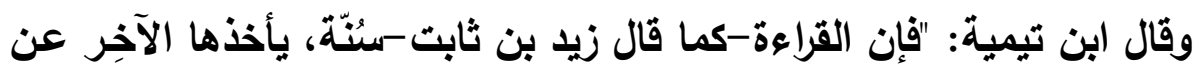

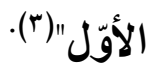

القاعدة الثانية : أن المعتمد في نقل القراءات وروايتها التلقي والمشافهة عن

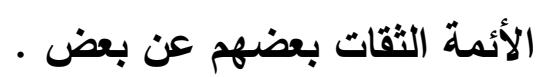

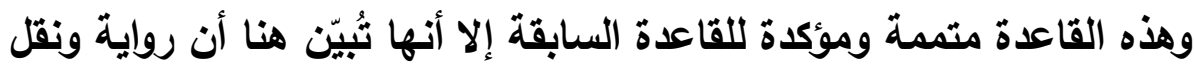

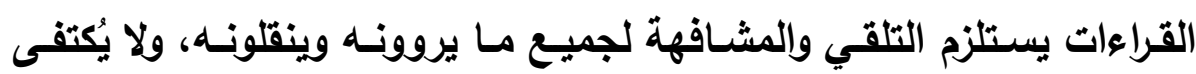

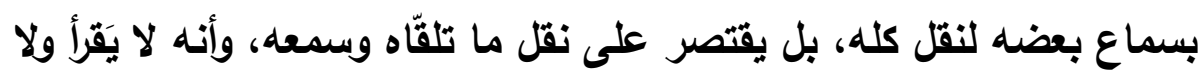
يُقَرئ إلا بما تلقّاه وسمعَه.

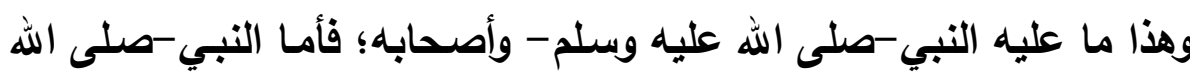

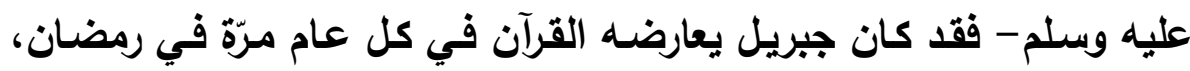
وعارضـه في العام الذي توفي فيـه-صلى الله عليه وسـلم - مرتين، وكـان

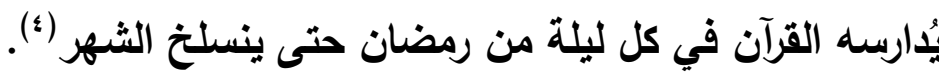

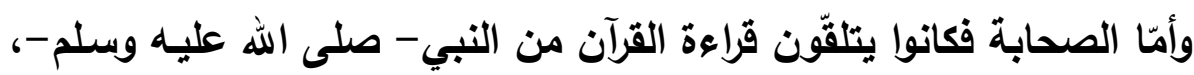

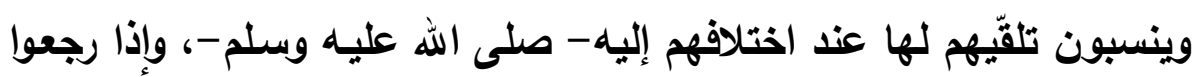

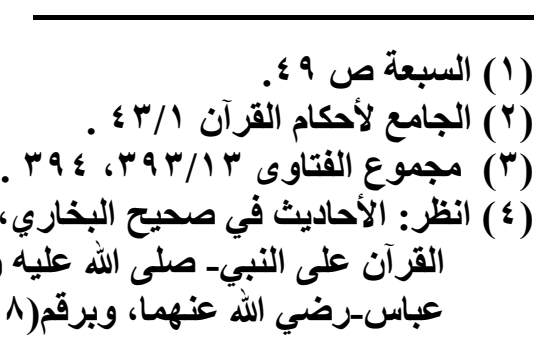

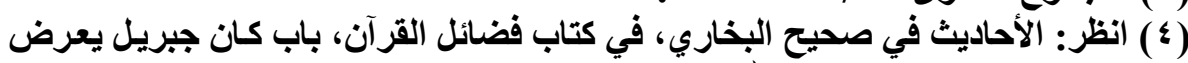

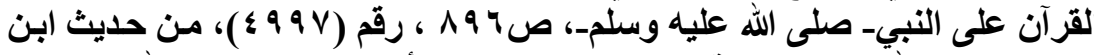

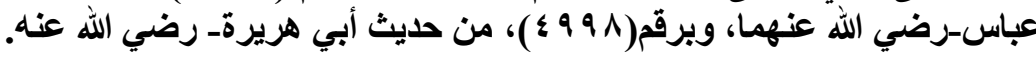


إليه استمع إلى تلاوتهم، وقال: „كذلك أُنزلته).

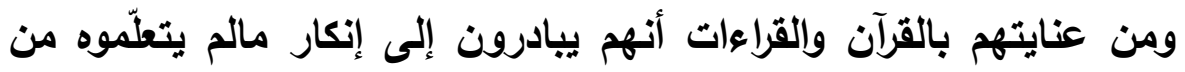

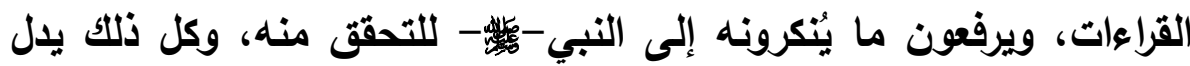

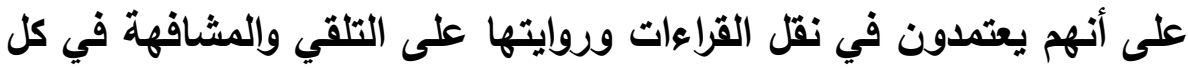
حرفٍ منها - كما سبق بيان ذلك في نزول القراءات. ومن الأمثلة على ذلكت قول عبدالله بن مسعود - رضسي الله عنهـ-: " والله لقد أخذت من في رسول الله- صلى الله عليه وسلم - بضعاً وسبعين سورة... ( (1) «

وسار على هذا الصحابة والتابعون ومَن بعدهم في تلقّي القرآن بعضهم عن بعض. قال ابن تيميـة:"ولم يُنكر أحد من العلمـاء قراءة العشرة، ولكن من لم يكن

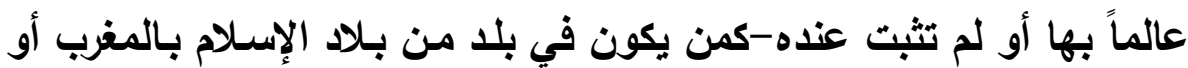

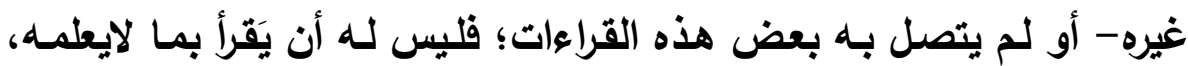

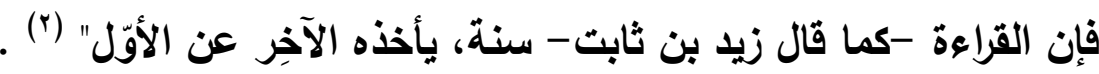

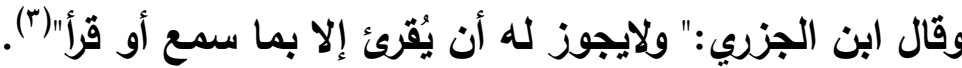

القاعدة الثالثة : أن أعداد القراءات كثيرة، اثتهر منها القراعات العشر.

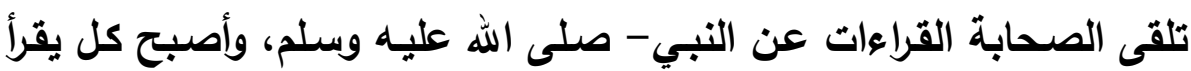

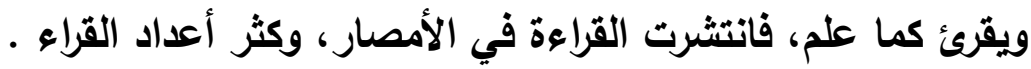


ولما اختلف الناس في القراءة في عهل عثمان - رضي الله عنه-، وخثي من الفتنة؛ جَمَعهم على مصحف واحد، وأرسل إلى كل مصر بمصحف، وأرسل

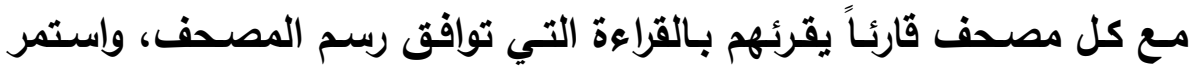
الناس على ذلك. ونظراً لكون القارئ يقرأ على أكثر من قارئ، وأن القارئ مُخيّر بأن يقرأ من

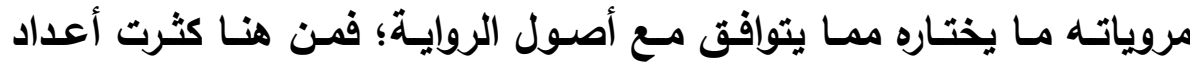

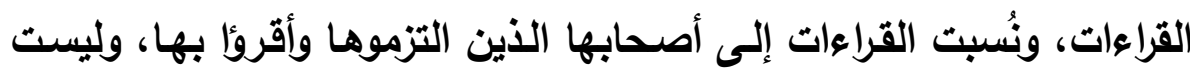
نسبة تفرد واجتهاد، كما أصبح لكل قارئ رواة يروون عنه قراءته.

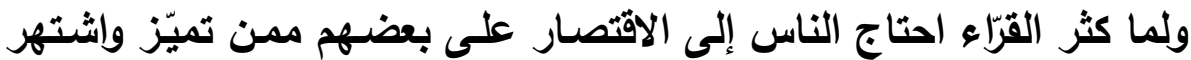

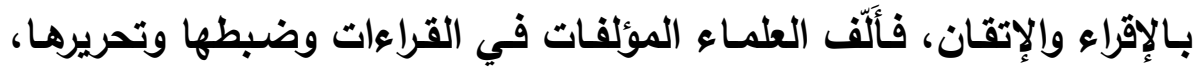

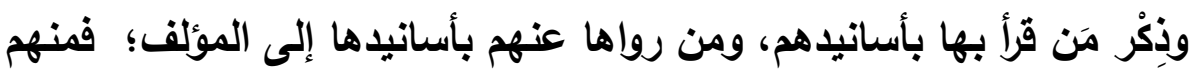

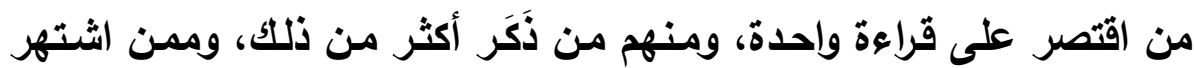

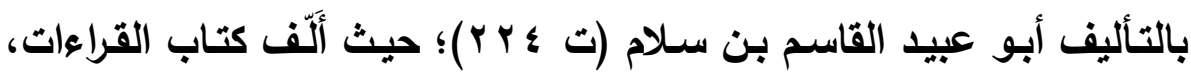

وجمع

فيها قراءة خمسة وعشرين قارئاً (1).

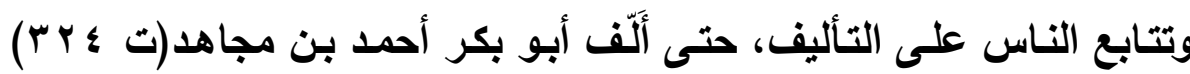
كتـاب: السبعة؛ اقتصـر فيـه على ضـبط وتحريـر قـراءة سـبعة مسن القـراء

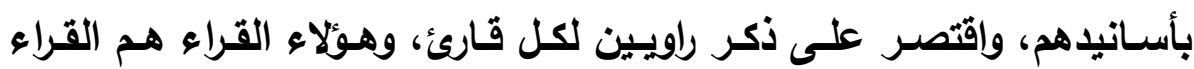

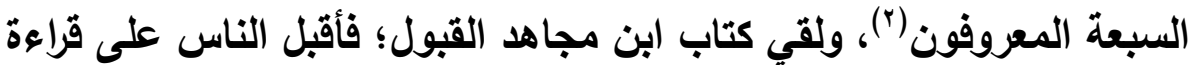

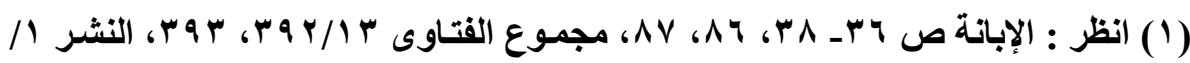

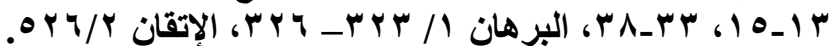

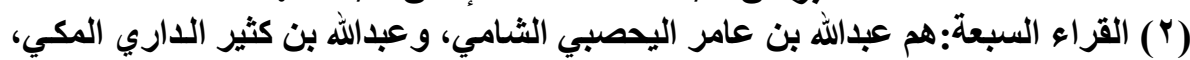

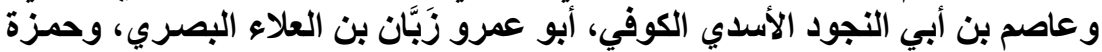

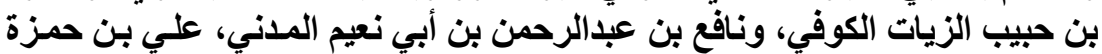

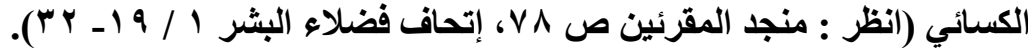




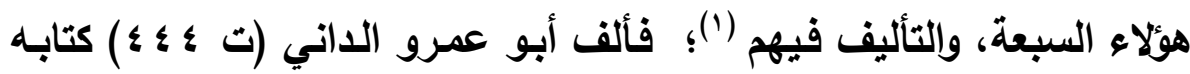

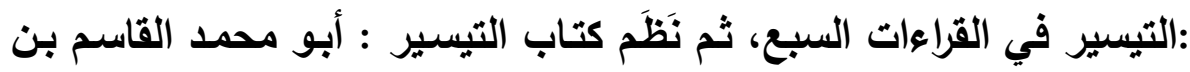

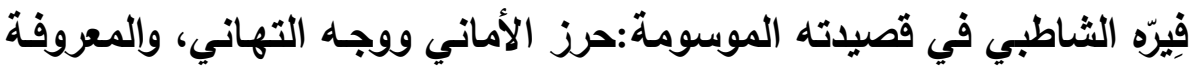
بالثاطبية) (ץ). كما تتابع الناس على التأليف : فأَلَّقوا في القراءات العثر - وهي قراءة القراء السبعة مع قراءة الأئمة الثلاثة المكملين للعشرة(").

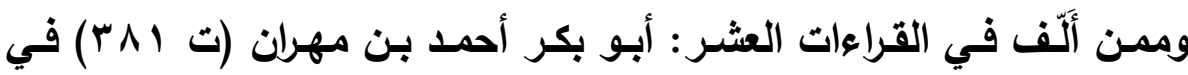
كتابه: الغاية في القراءات العشر (4).

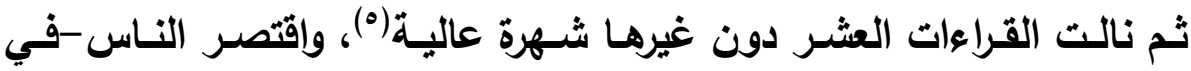

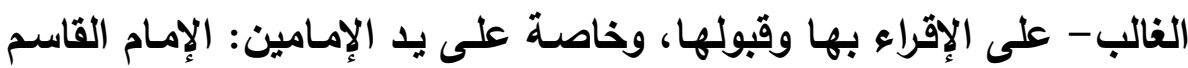

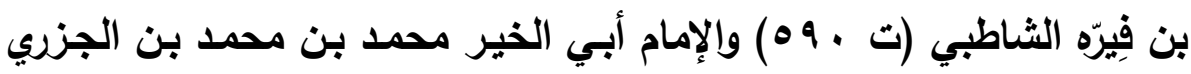

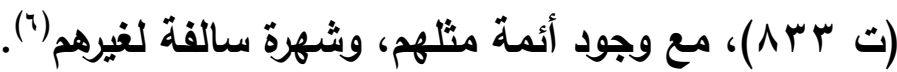

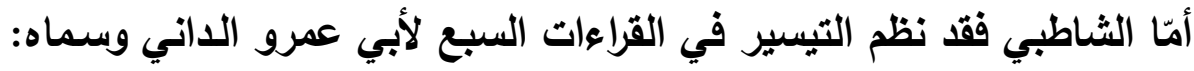
حرز الأماني ووجه التهاني، والمعروف بالثـاطبية أو اللاميّة؛ فاهتم الناس

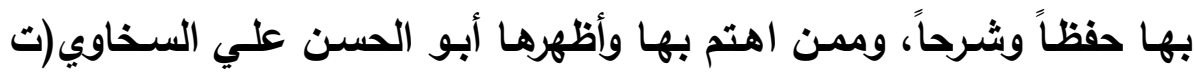

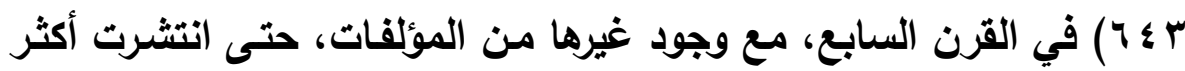

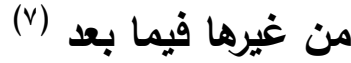

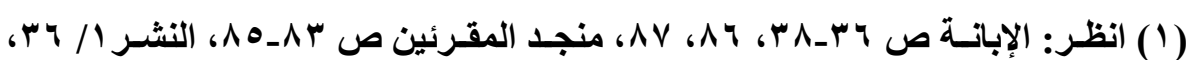

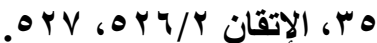

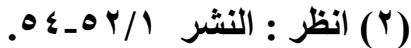

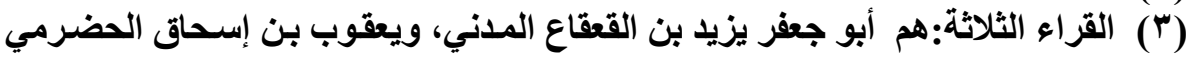

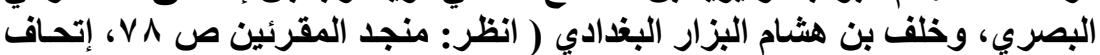

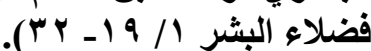

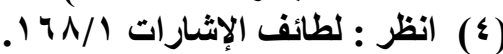

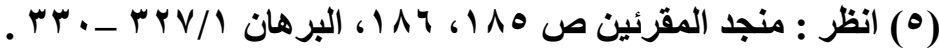

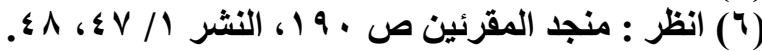

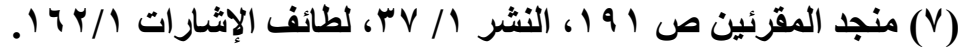


وأما ابن الجزري فقد نظم القراءات الثثلاث المتممـة للعشر من كتابه: تحبير

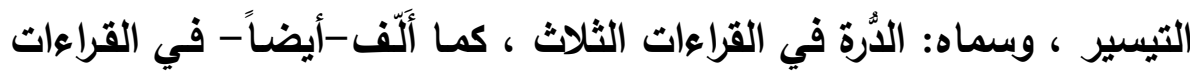

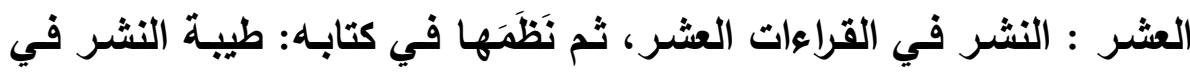
القراءات العشر ، ثم لاقت كتبه القبول .

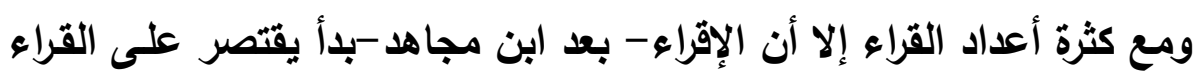
العشرة في القبول، حتى استقزّ الأمر عليها. وشهرة قارئ من القراء تختلف حسب الزمان والمكان والتلاميذ والولاية، وأكثر

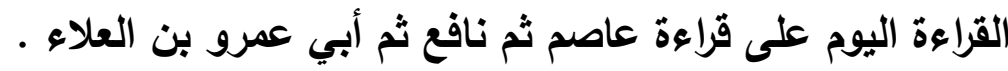

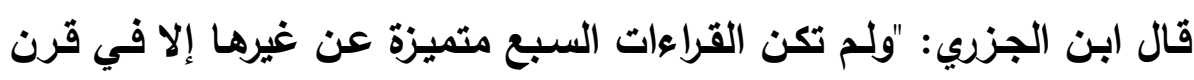

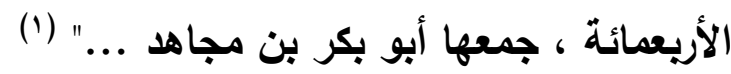
ويلخل تحت هذه القاعدة القواعد التالية : القاعدة الفرعبة الأولى : أن القراء عددهم كثير، ومنهم هؤلاء العشرة، كما أن

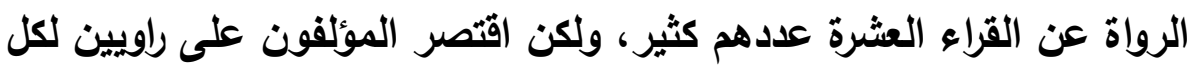
قارئ للشهادة والرواية والاختصار (†).

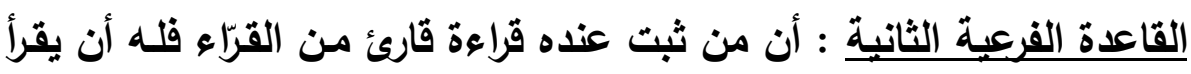

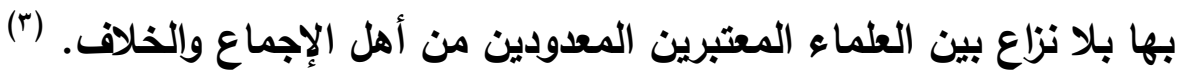

القاعدة الفرعية الثالثة : أن التمسك بقراءة سبعة من القراء دون غيرهم ليس

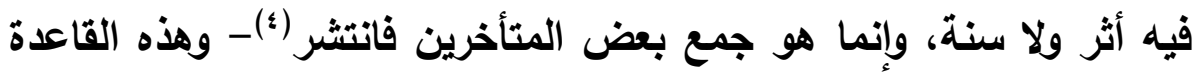

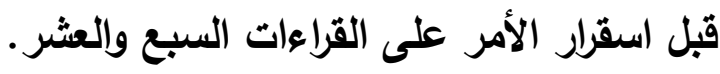

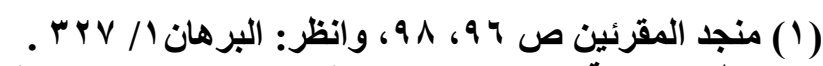

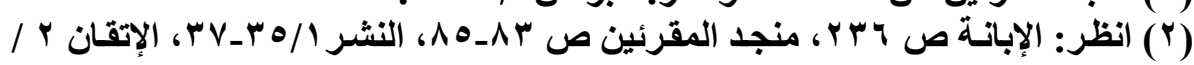

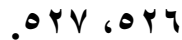

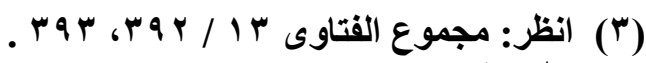

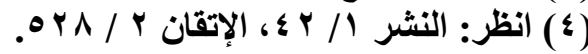


القاعدة الفرعية الرايعة : أن القراءات السبع لم تكن متميزة عن غيرها إلا في

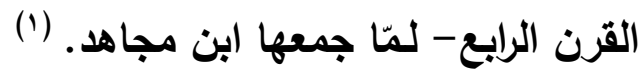

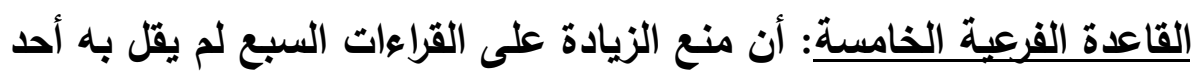

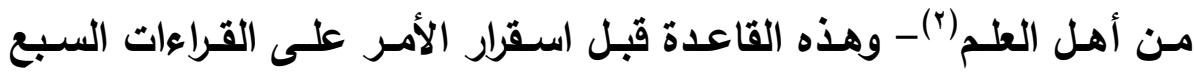
والعثر.

القاعدة الرابعة: أن القراءات العشر متواترة. القراءات العشر هي القراءات المنسوية للقراء العشرة("). وهذه القراءات العشر متواترة بالإجماع ، ولم ينكرها أحد من العلماءعاء).

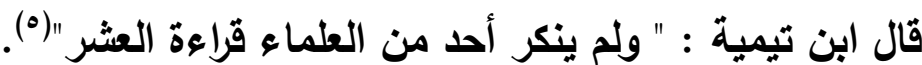
وقـال عبد الوهـاب السبكي-عن سـؤال ابـن الجزري عن تـواتر العشـر-:" القراءات العثر - السبع التي اقتصر عليها الثاطبي، والثلاث التي هي قراءة أبي جعفر وقراءة يعقوب وقراءة خلف- متواترة معلومة من الدين بالضرورة، وكل حرف انفرد به واحد من العشرة متوات، معلوم من الاين بالضرورة أنه

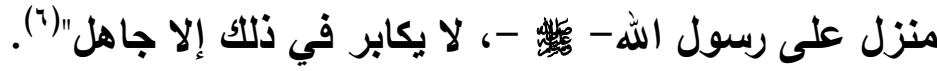

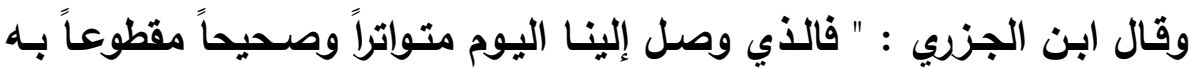
قراعات الأئمة العشرة الجزية ورواتهم المشهورين" (v')

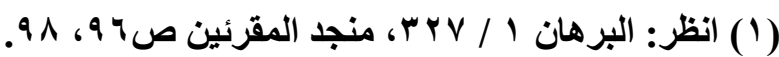

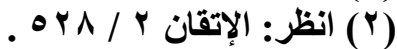

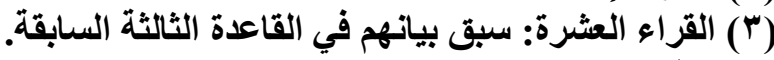

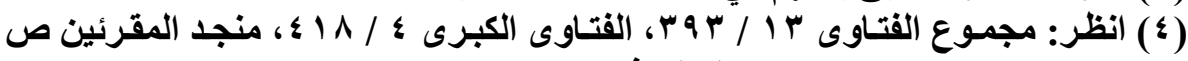

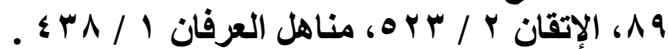


وقال -أيضاً - " العثر لا زالت مشهورة من لان قرئ بها إلى اليوم،لم ينكرها أحل من السلف ولا من الخلف، هذا شيء لا يثك فيه أحد من العلماء "( (1).

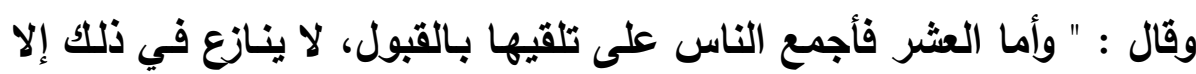
جاهل " (r) (ب)

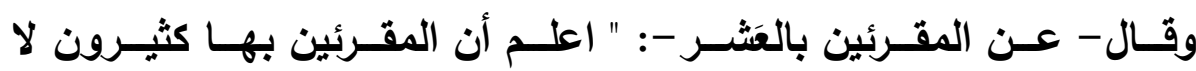

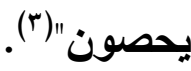
ويلخل تحت هذه القاعدة القواعد التالية :

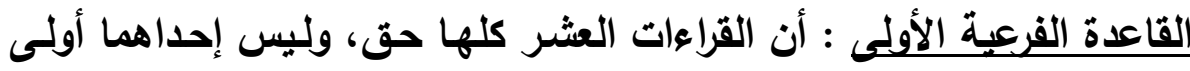

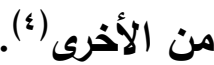
القاعدة الفرعية الثانية : أنها لا فرق بين قراءات الأئمة السبعة وبين قراءة أحد الأئمة الثلاثة(ْ). قال ابن الجزري : " والذي جمع في زمانتا هذه الأركان الثلاثة : هو قراءة

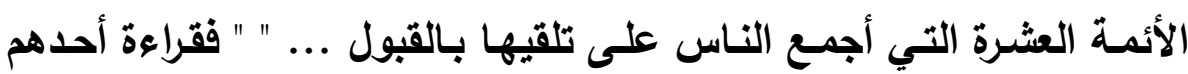

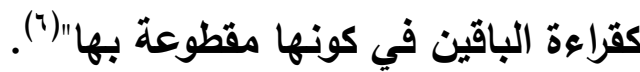
كما أن القراءات الثلاث ترجع إلى القراءات السبع (v)

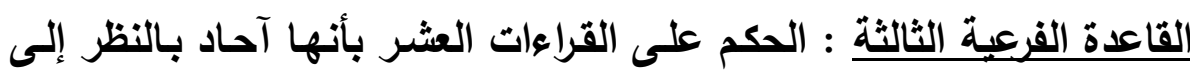

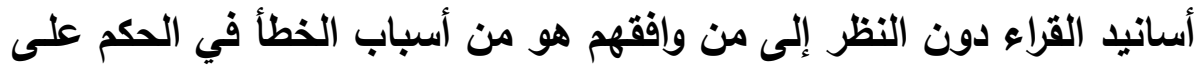

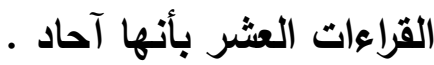

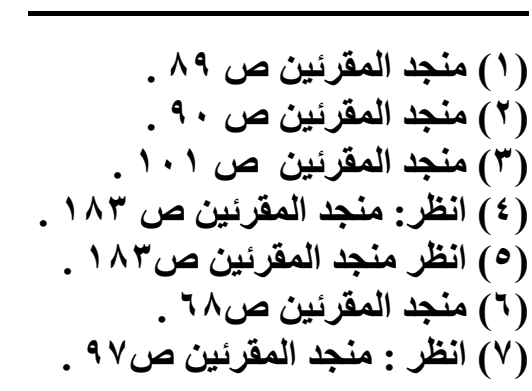


القاعدة الفرعية الرايعة : أن القراءة إذا استجمعت شروط القراءة الصحيحة،

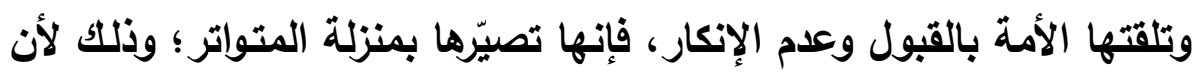

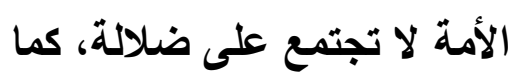
أن هذا من حفظ الله للقرآن، وقد تكفل الله بحفظه . ونقد آحاد الناس للقراءة الصحيحة المقبولية لا يؤثثر؛ لأن الخطأ إليهه أقرب،

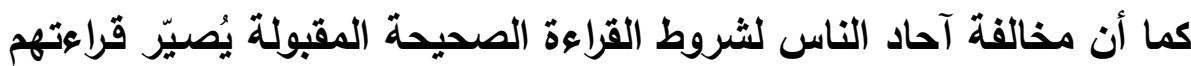

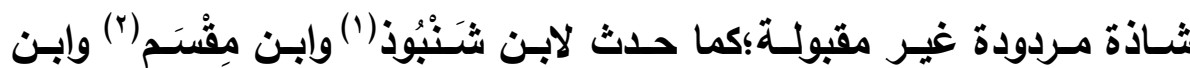

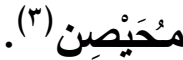

القاعدة الخامسة : أن القراءات العشر متواترة اتفاقاً واختلافاً. وبيان هذه القاعدة : أن القراءات العشر الواردة عن القراء العشرة؛ منها مـا اتفق عليها القراء العشرة في قراءة لفظها على وجهه واحد، ومنها مـا اختلفوا في قراءة لفظها على أكثر من وجه.

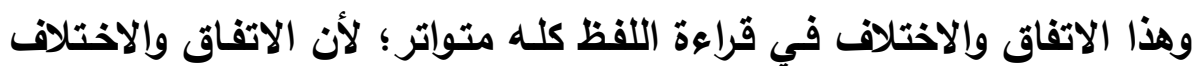

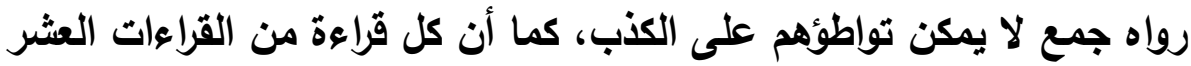

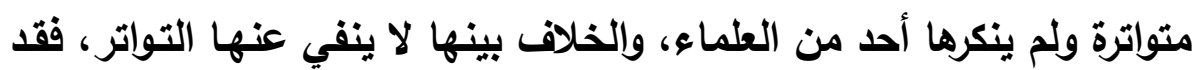
يجتمع التواتر والتخالف (๕). والمقصود من إيراد هذه القاعدة هو الرد على دعوى بأن القراءات العشر

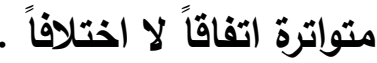


وممن نُقل عنه هذا القول : أبو شامة في كتابه المرثد الوجيز (').

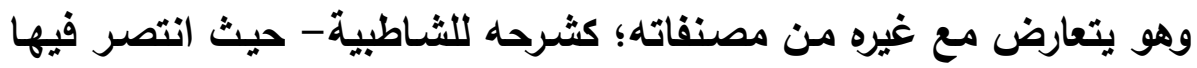
للقراءات العشر التي قُّح فيها، مع كون هذه من القراءات منسوية إلى قارئ من القراء العشرة، وليست إليهم جميعاً .

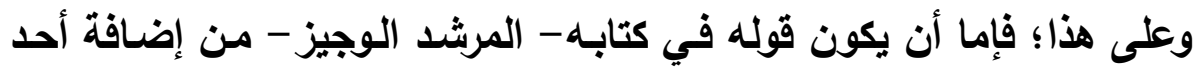

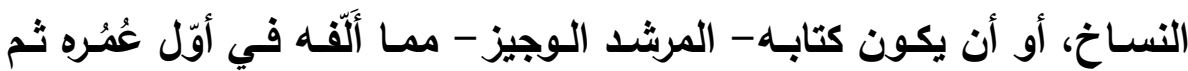

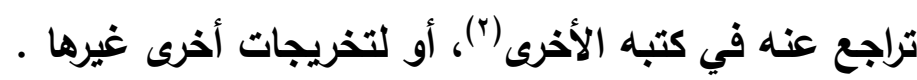

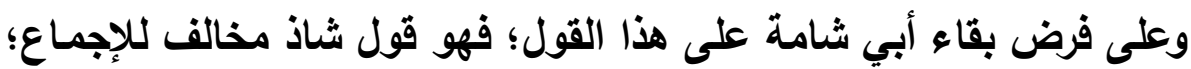

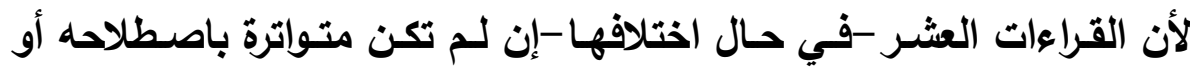
اجتهاده؛ فهي متواترة حقيقة في حال اتفاقها واختلافها، مـع تلقي الأمـة لها لها

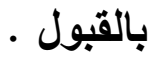

القاعدة السادسة : أن القراءات العشر متواترة أصولاً وفرشاً.

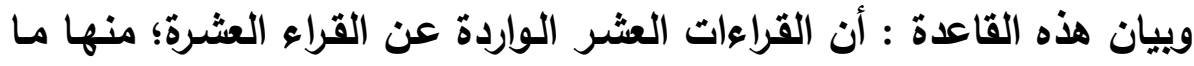

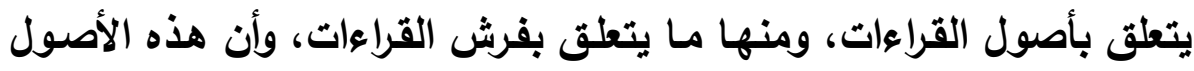

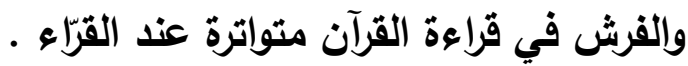

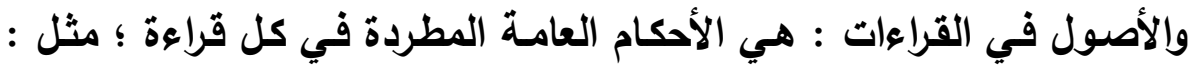

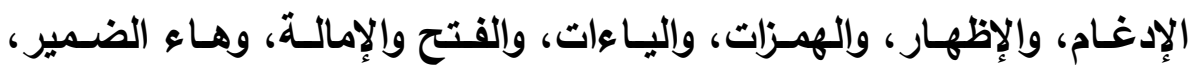

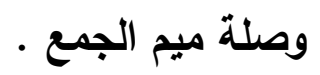
وأما الفرش في القراءات: فهو الكلمات القرآنية التي لها قراعة خاصة في كل

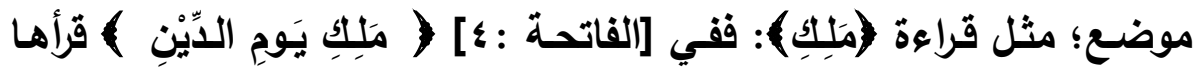


عاصم والكسائي ويعقوب وخلف بالألف (مَالتِكِ) وقرأها الباقون بدون ألف

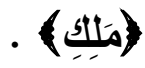

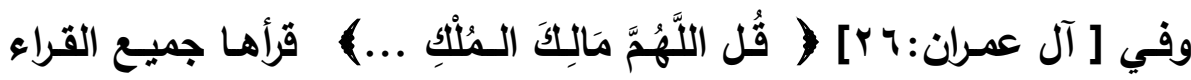

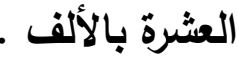
وفي سـورة [النـاس :r] (مَلِّكِ النَّاسِ ) قرأهـا جميع القراء العشـرة بـدون

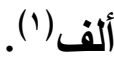
والمقصود من إيراد هذه القاعدة هو الردّ على دعوى بأن القراءات العشر

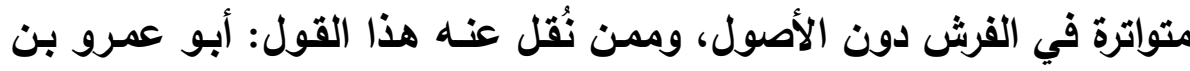
الحاجب في مختصر الأصول (ץ). وهذا القول مخالف لمـا عليه أئمة القراءات في تلقي القراءات والإقراء بها أصولاً وفرشثاً. ومخالف لما نصّ عليه بعض أئمة القراءات إجمالاً أو تفصيلاً: بأن الأصول متواترة؛ كأبي القاسم

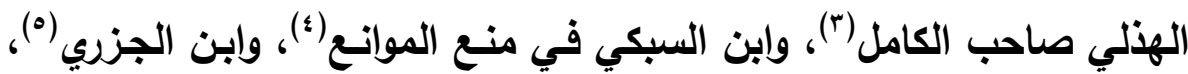

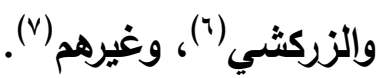

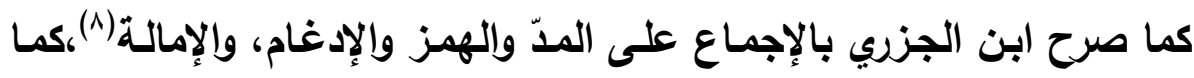

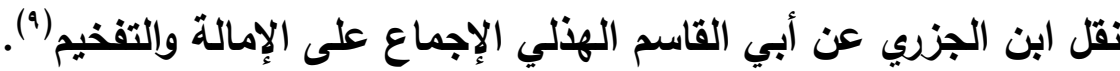

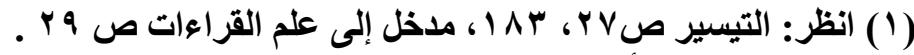

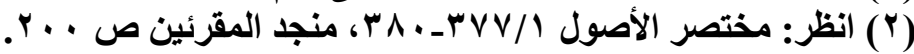

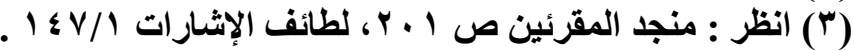

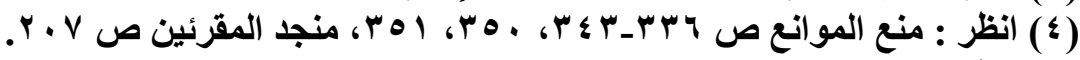

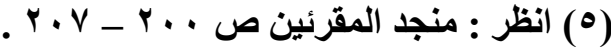

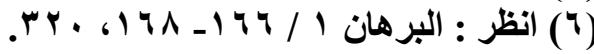

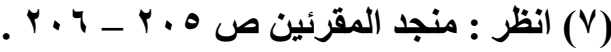

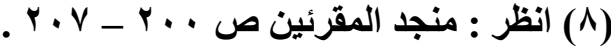

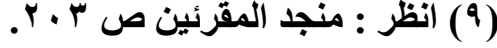


واعتُّر لابن الحاجب بـأن قولـه هذا لا يوجد في النسـخ المشـهورة لكتابـه

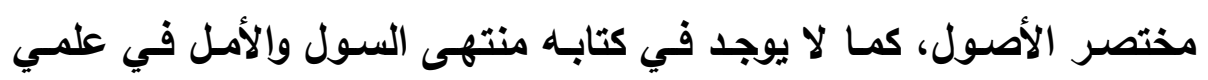

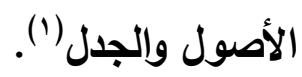
" قال أبو القاسم الهذلي: وقد أجمعت الأمـة من للن رسول الله-صلى الله عليه وسـلم- إلى يومنـا هذا على الأخذ والقراءة والإقراء بالإمالـة والتفخيم .( $\left.{ }^{(\top)}\right)^{\prime} \ldots$

وقال الزركثي - في قول ابن الحاجب بأن أصسول القراءات السبع ليست

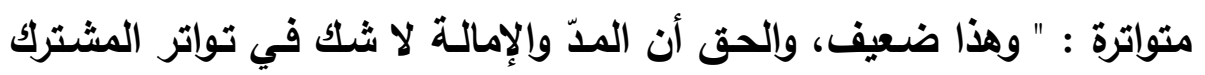

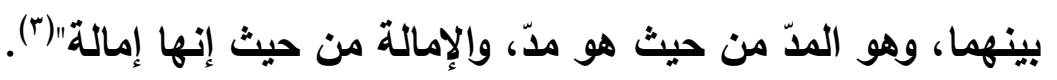

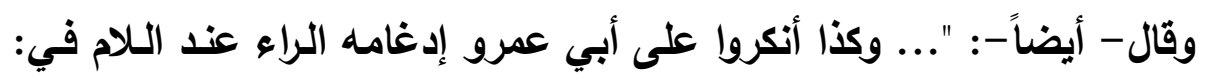

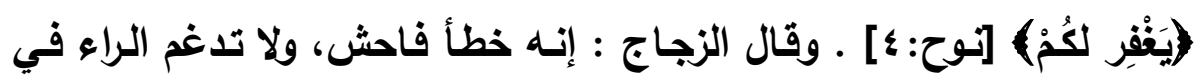

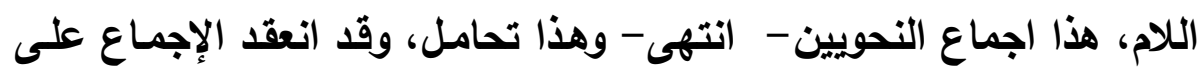

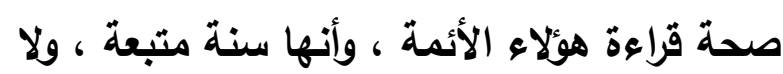

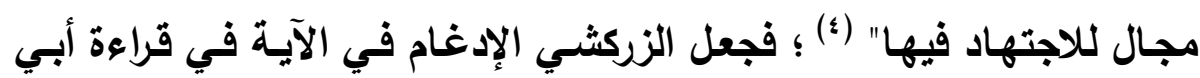
عمرو مما أُجمع عليه . مجناد فيال وقال ابن الجزري- في الأصول والفرش- - " وقد نص على تلى تواتر ذلك كله أئمسة الأصول كالقاضي أبي بكر بن الطيب البـاقلاني في كتابه الانتصـار

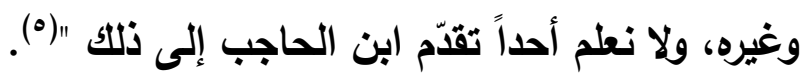

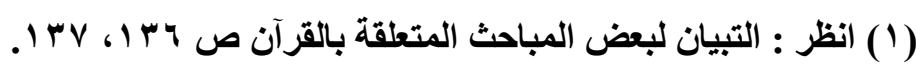

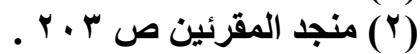

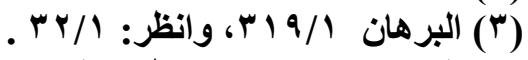

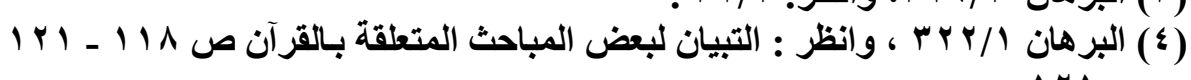
الير هان

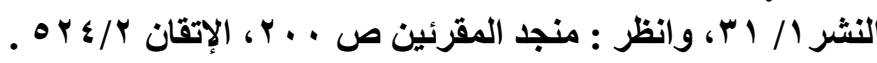


كما بين ابن الجزري: بأنها إذا ثبت تواتر اللفظ ثبت تواتر هيئة أدائهـ؛ لأن

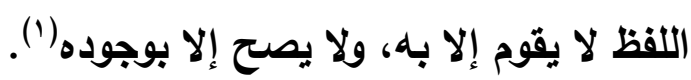
ومما ياخل تحت هذه القاعدة القاعد التالية:

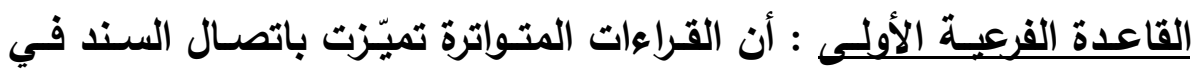
نطقها، كما تميّزت بنقل ألفاظها.

القاعدة السابعة: أن القراءات العشر متواترة من للان رسول الله- صلى الله عليه وسلم - إلى منتهاها . وييان هذه القاعدة : أن القراءات العشر الواردة عن القراء العشرة متواترة من

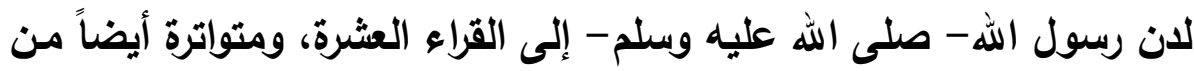

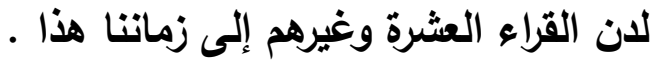

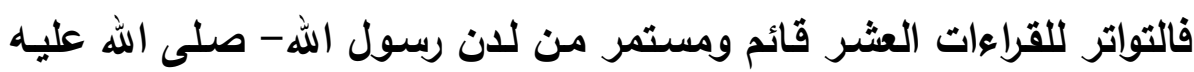

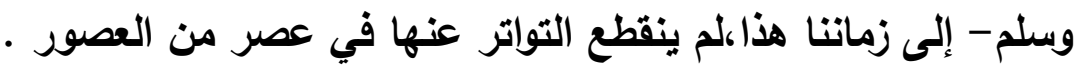

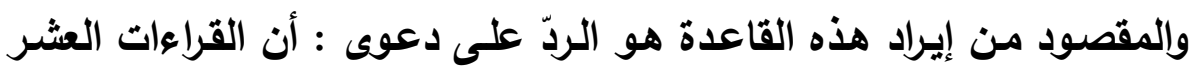

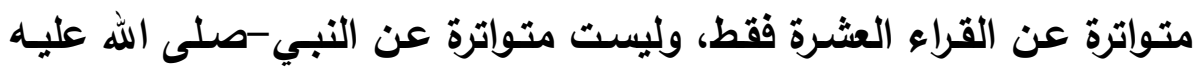
وسلم - إلى القراء العشرة. وممن نُقل عنه هذا القول: أبو شـامه في المرشد الوجيز (†)، والزركثـي في

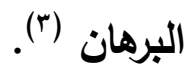
وسبب هذا القول في نظرهم : أن أسـانيد القراء العشرة بهذه القراعات العشر

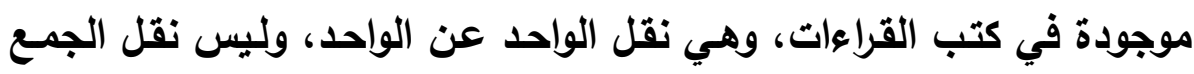

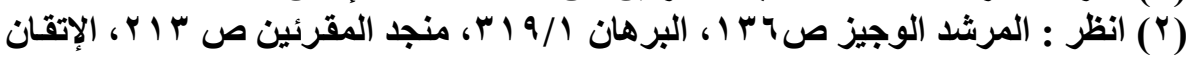


عن الجمع، ولذا فأسانيدهم أسانبد آحاد، وليست أسانيد تواتر ('). ومنشأ هذا الخطأ من وجهين: الوجه الأول : أنهم نظروا إلى نسبة القراءة للقراء بأنها نسبة تفرد أو آحاد،

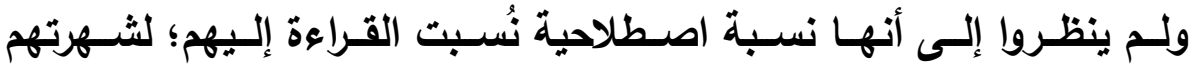
وانشتغالهم بها، لا لتفردهم بها. الوجه الثاني : أنهم نظروا إلى أسانيد القراء، ولم ينظروا إلى من وافقهم من القراء الآخرين؛ لأن عدد التواتر موجود في كل طبقة-كما هو مدّون في كتب القراءات-، كما أن اقتصار كتب القراءات العشر على بعض الأسانيد؛ لا ينفي

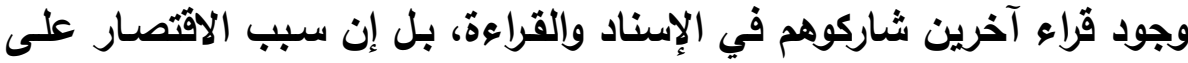

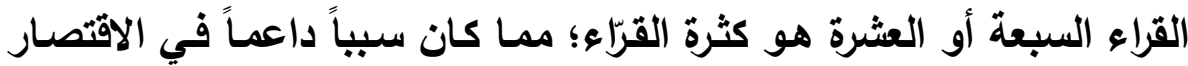
على القرّاء العشرة(؟). وإذا ارتفع وَهْمُ القائلين بهذا القول انتظموا في الإجماع ولْم يختلفوا؛ لأن عدم القماء

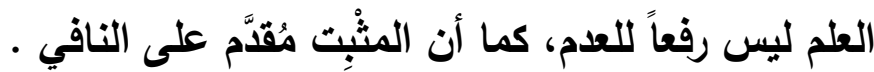

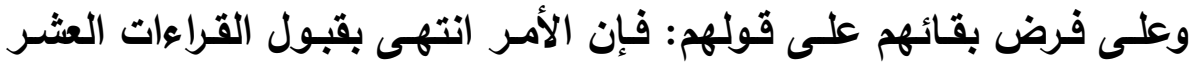

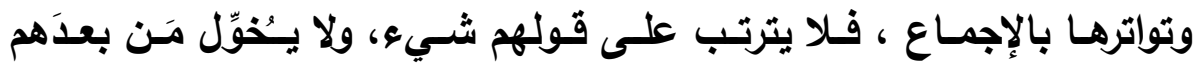

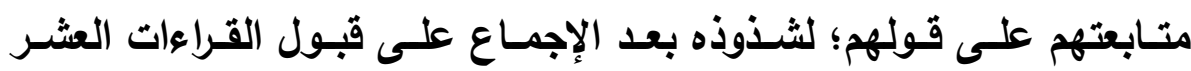

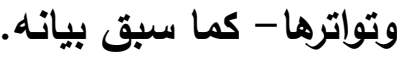
قال ابن الجزري - في القراء السبعة-: "وتعيينهم إمـا لكونهم تصدّوا للإقراء

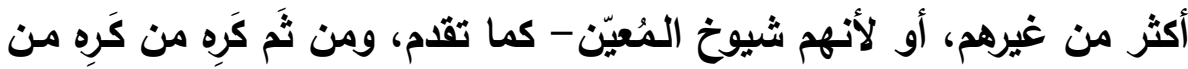

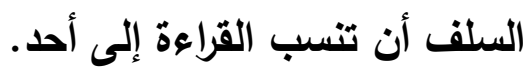

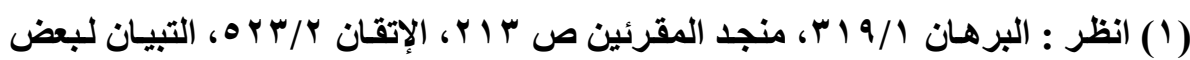

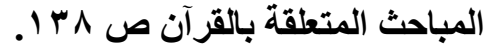

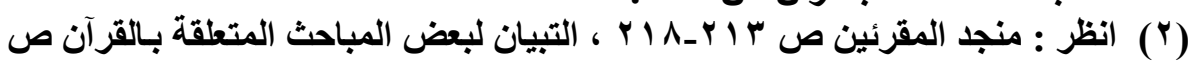


روى ابن أبي داود عن إبراهيم النخعي قال: كانوا يكرهون سند فلان وقراءة

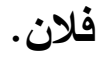

قلت(ابن الجزري): وذلك خوفاً مما توهمه أبو شامة من أن القراعة إذا نُسبت

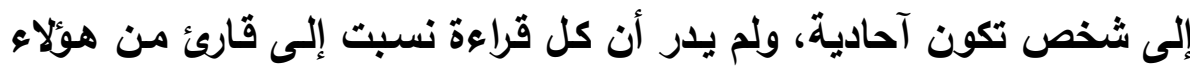

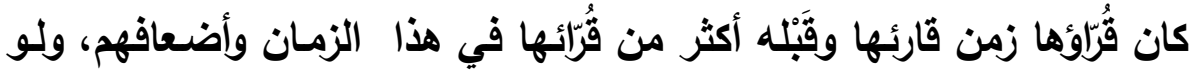

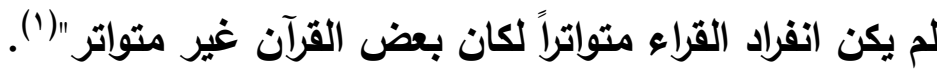

القاعدة الثامنة: أن تواتر القراعات الثّلاثة المتمة للعشر كتواتر السبع.

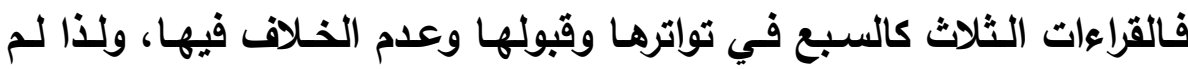
ينص أحدٌ من العلماء على شذوذ القراءات الثُلاث.

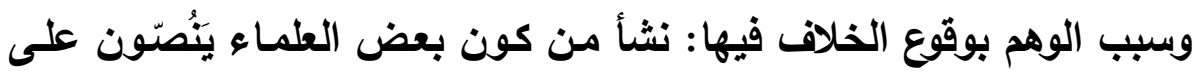
تواتر السبع فقط؛ فيفهم بعض الناس من هذا التنصيص: أن مـا عدا السبع شاذ، ثم يتوهّمون: أن القراءات الثلاث شاذة.

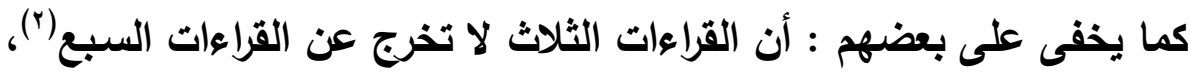
وممن حصل لله هذا: الإمـام عبد الوهاب السبكي، حيث فهم من قول ابن

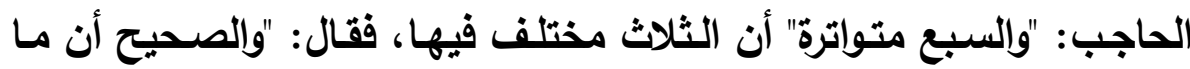
وراء العشر فهو شاذ" ، فقوله " والصحيح" يدل على أنها فَهِمَ أن في الثُلاث

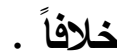
وهذا الفهم نازعه فيه ابنُ الجزري، وطالبه بالخلاف والقائل فلم يَقْدر عليه، ثم تراجع السبكي عن فهمه، ولكنه توفي قبل أن يغيّر هذا الفهم في كتابه جمع 


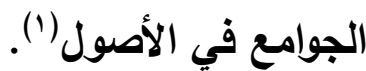

وأيضاً من أسباب الوهم بوقوع الخلاف في الثلاث: قول بعضهم -كالسخاوي -

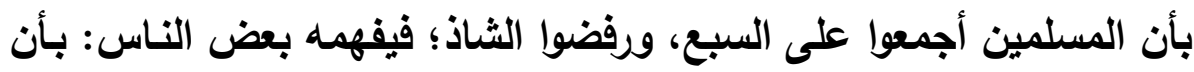

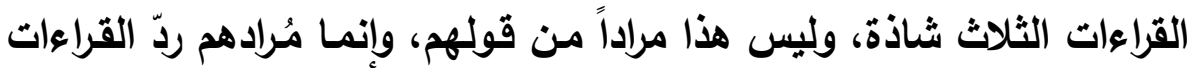

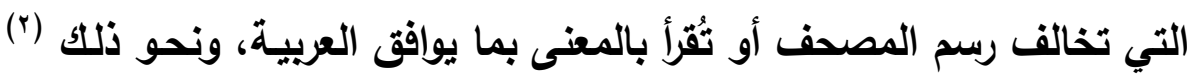

قال ابن الجزري: " لانعلم أحداً من المسلمين حظر القراءة بالثلاث الزائدة

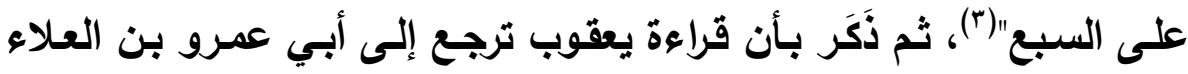

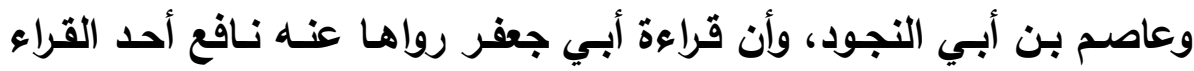
السبعة، وأن قراءة خلف بن هشام ترجع إلى حمزة، وما خالف فيه حمزة فإنها

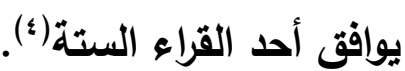

القاعدة التاسعة: أن تواتر القراءات العشر من حيث مجموع القراء في كل طبقة، لا من حيث أسانيد القراء العشرة. وهذه القاعدة مُبينة للقاعدة السابقة بأن القراءات العشر متواترة .

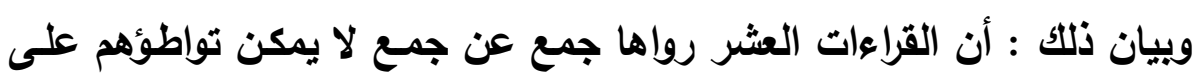

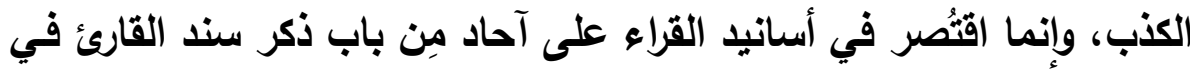
هذه القراءة، وليس من باب حصر سند القراءة بطريق هذا القارئ.

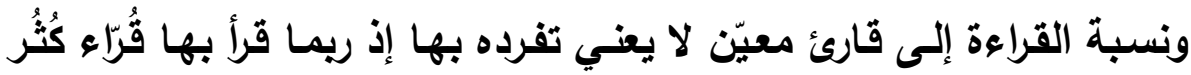

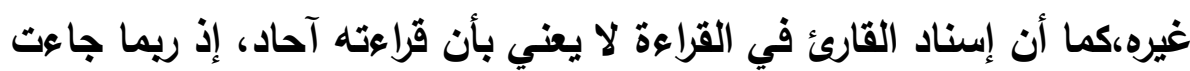

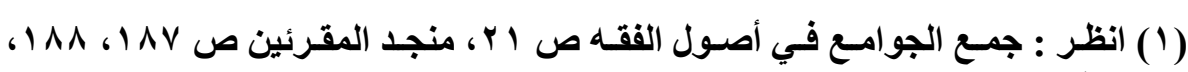

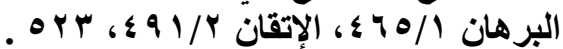

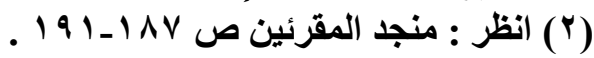
(4)

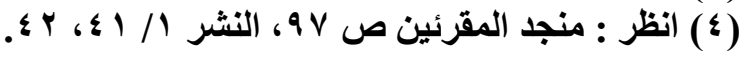


من طرق متعددة؛ لأن المعتبر في التواتر في القراءة هو تـواتر القراءة

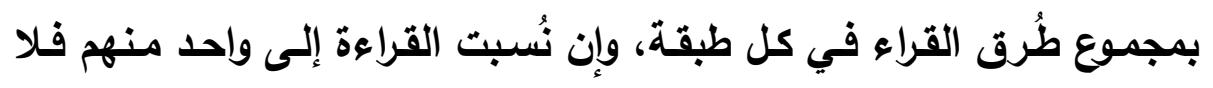

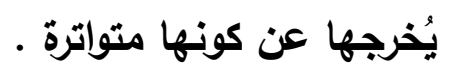

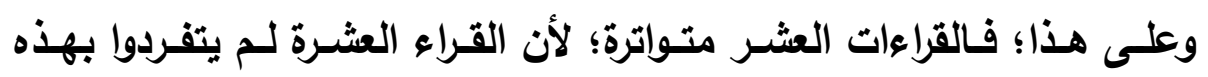

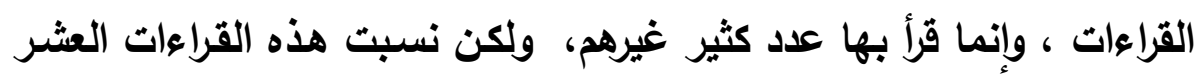

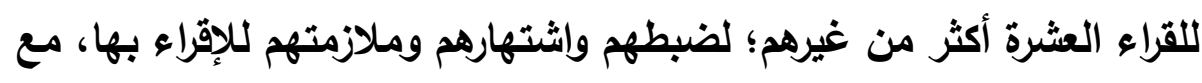

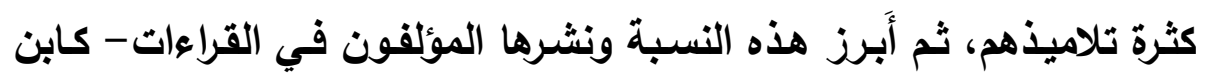

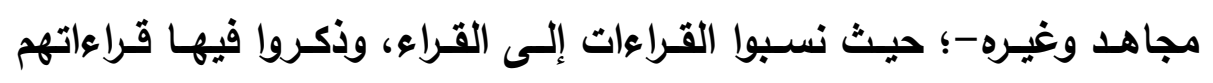
وأسانيدهم فيها، ورواتهم لها، وتلقى الناس هذه المؤليفات بالقبول.

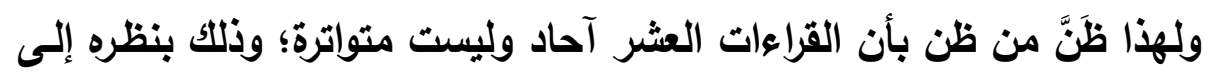

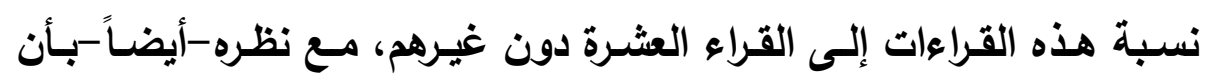

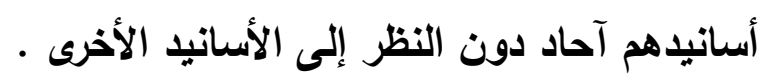

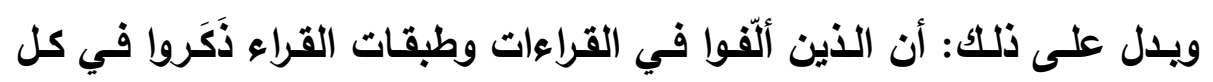

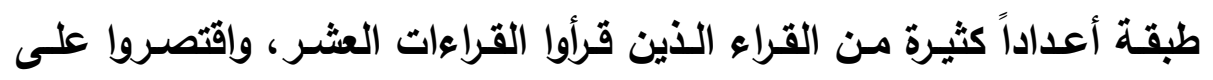
هؤلاء الذين ذكروهم لشهرتهم، ولم يحصروا جميع القراء في كل طبقة؛ لأنسه يصعب حصرهم لكثرتهم، وكثرتهم راجعة إلى أن القزآن مصدر تثريعهم، يتلوه

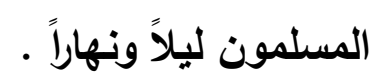

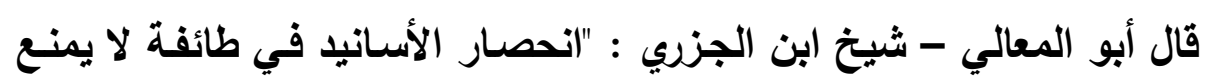

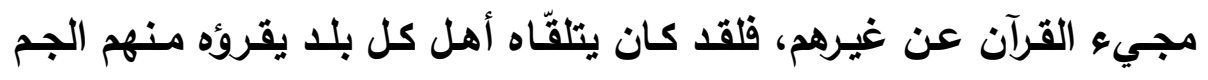

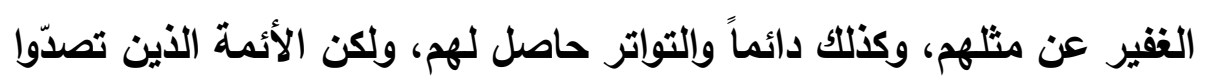
لضبط الحروف وحفظوا شيوخهم منها جاء السند من جهتهم. وهذه الأخبار

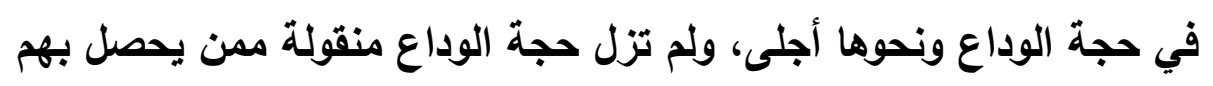


التواتر عن مثلهم في كل عصر، فهذه كذلك" (') . (1)

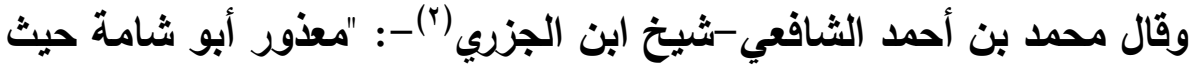

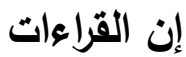

كالحديث مخرجها كمخرجه إذا كان مدارها على واحد كانت آحاديـة ، وخفي عليه أنها نسبت إلى ذلك الإمام اصطلاحاً ، وإلا فكل أهل بلد كانوا يقرؤونها، أخذوها أمماً عن

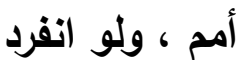
واحد بقراءة دون أهل بلده لـم يوافقه على ذلكك أحد، بل كانوا يجتنبونها

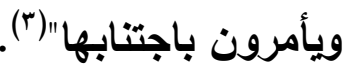

القاعدة العاثرة : الإجماع قائم على قبول القراءات العشر وتواترها، ولا يقدح فيه شذوذ المخالِف أو المشاحة في الاصطلاح.

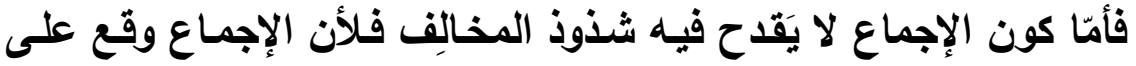
قبول القراءات العشر وتواترهـا قبل وجـود المخـالفِ لو ظهر ، ويعد ظهور المخالف لو وُجد؛؛ فيكون خلافه شاذاً غير معتبر.

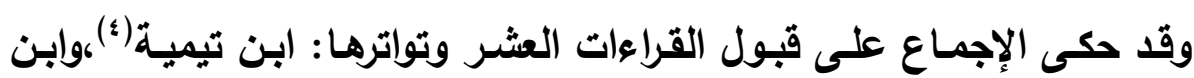

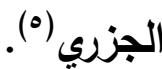

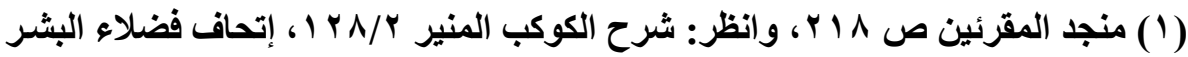

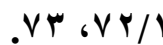

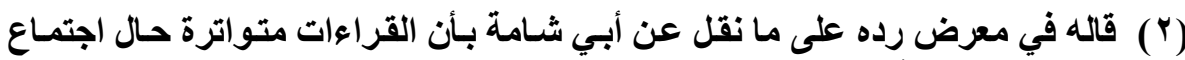

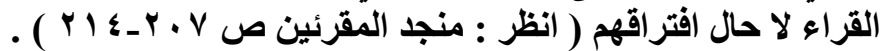

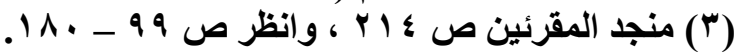

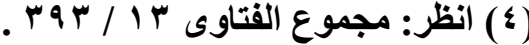

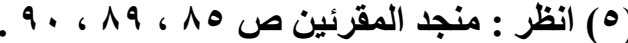




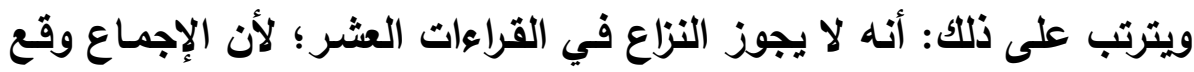

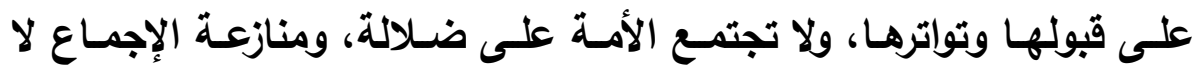

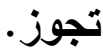

وأمّا أن الإجماع لا يقدح فيه المشاحة في الاصطلاح فلأن الأمة إذا تلقّت الخبر أو القراءة بالقبول فإنه يصيّره بمنزلة المتواتر المفيد للعلم، سواء أَظَهَه

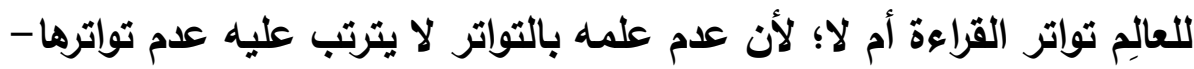

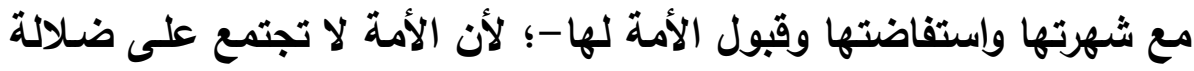

كما أن المقصود بالتواتر هو إفادة العلم واستفاضته وقبول الأمة له من غير

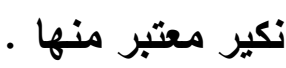
كما أن تقدير عددٍ للتواتر إنما هو لإفادة حصول العلم اليقيني للخبر، وليس

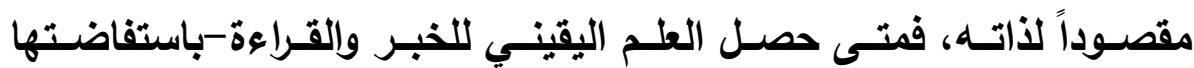

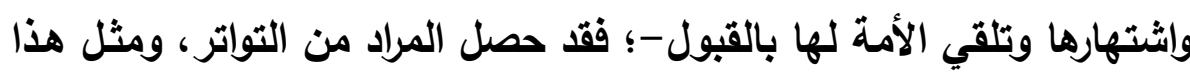
لا يكون إلا بعدد يحصل به الاستفاضة والقبول، ولكن من غير تقدير لعدد.

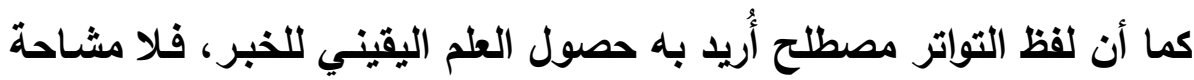

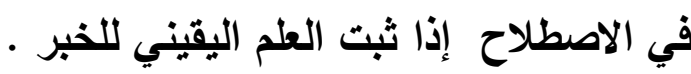

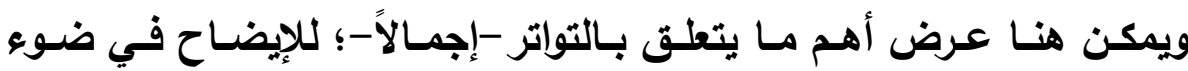

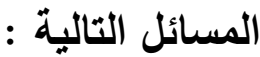

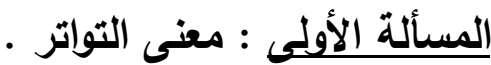

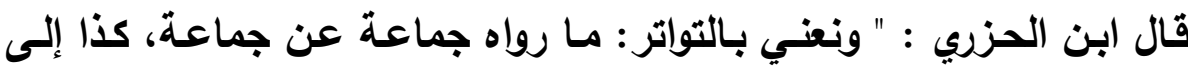

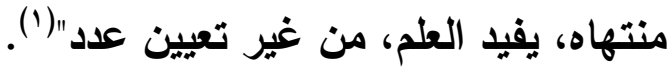

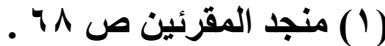


فإذاً المراد من التواتر : هو إقادة العلم- وهذا حاصل في القراءات العشر (1).

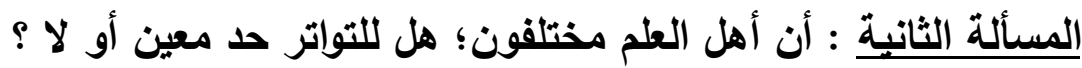

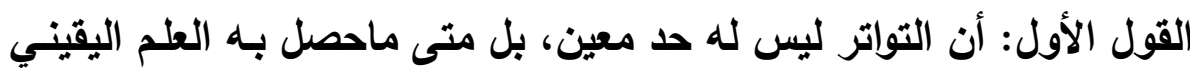

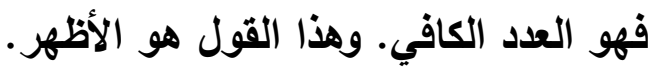
القول الثاني: أن التواتر له حد معين.

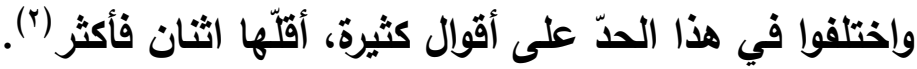

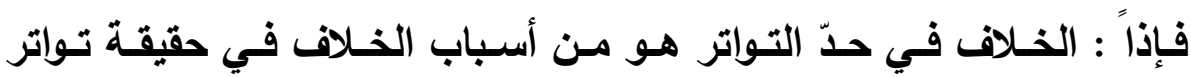

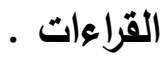

المسألة الثالثة : أن أهل العلم مختلفون في إفادة خبر الآحاد للعلم وقبوله :

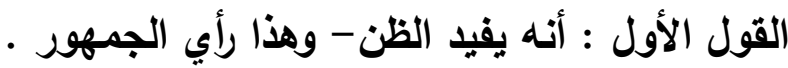
القول الثاني : أنه يفيد اليقين • القول الثالث : أنه إذا احتقّت بـه قرائن فإنهه يفيد اليقين - وهو الأظهر؛ لأن

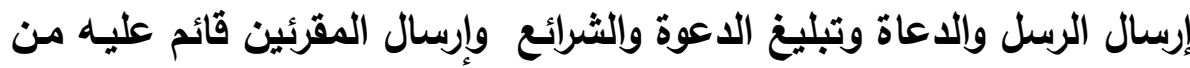
غير نكير ("). قال ابن الجزري : " ولو أدخل شخص بعض القراعات العشر إلى بَّلْةٍ لم تكن

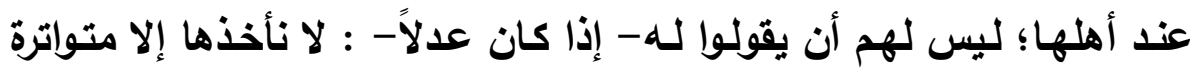

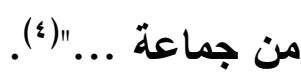
ويهذا يزول الإثكال حول ثبوت أداء بعض طرق أوجه القراءة الصحيحة عن العشرة وأنها في حكم المتواتر.

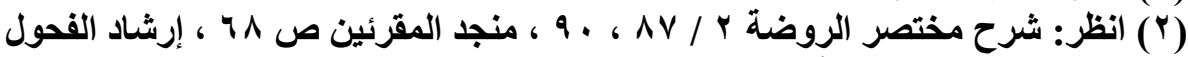

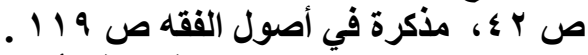

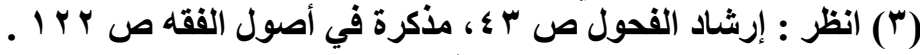

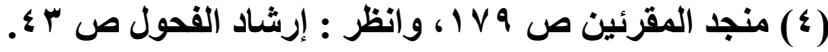


المسألة الرابعة : أن خبر الآحاد يفيد العلم إذا تلقّته الأمـة بالقبول، ويصيّره

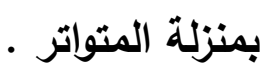

قال الجصاص : " خبر الواحد إذا تلقّاه الناس بالقبول؛ صـار بمنزلية

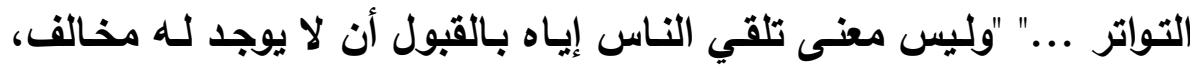

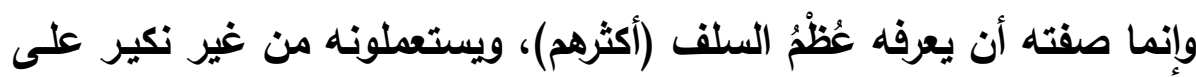

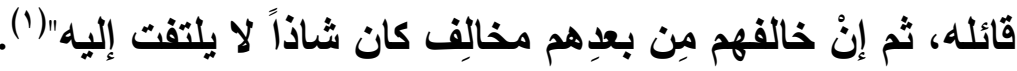

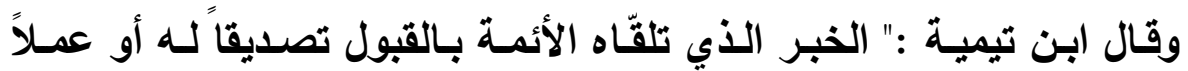

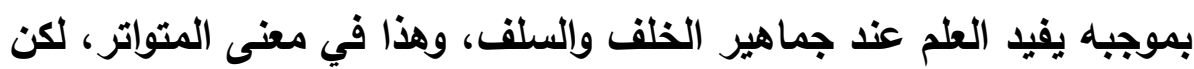

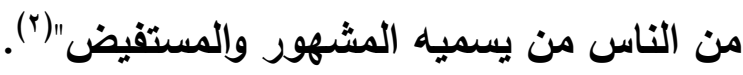
وقال-أيضاً-: " فالخبر الذي رواه الواحد من الصحابة والاثنان إذا تلقته

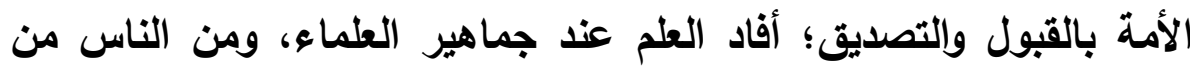

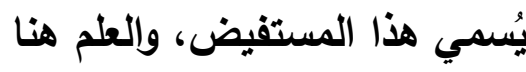

حاصل بإجماع العلماء على صحته، فإن الإجماع لا يكون على خطأ"((").

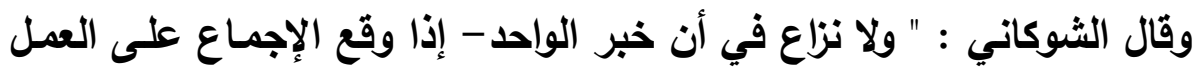

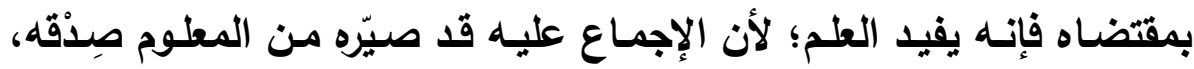

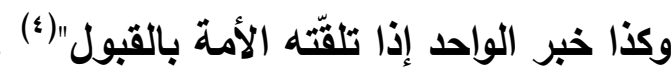
وقال ابن الجزي : " والعدل الضابط: إذا انفرد بشيء تحتمله العربية والرسم، بالهول

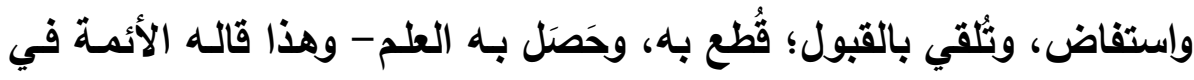

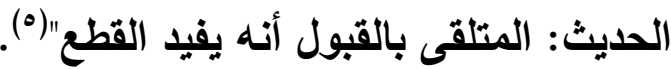

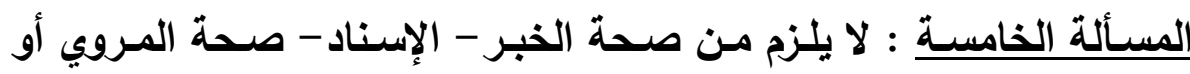


قبوله أو العمل به؛ لعدم اكتمـال شروط القبول فيه؛ ككونـه شـاذاً أو منسوخاً

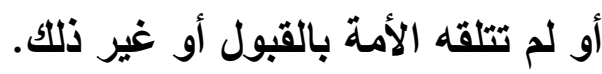

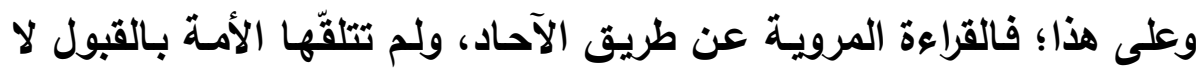
تعتبر قرآناً، بل تعتبر قراءة شاذة - ويهذا يزول الإثكال حول قراعات الآحاد الادي

القاعدة الحاديـة عشرة : تواتر القراءة عند قوم عدولٍ كتواترهـا عند جميع

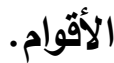

القراءة ريما تكون متواترة عند قوم دون قوم آخرين - وهذا لا يستلزم ردّها،

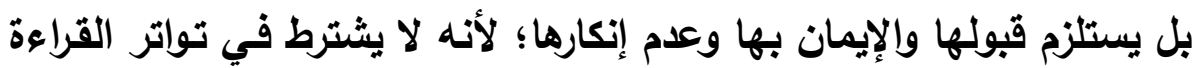

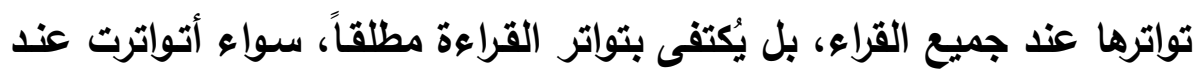
جميع الأقوام أو قوم دون قوم - كحال الصحابة في عدم معرفة بعضهم بيقية الأحرف السبعة؛ لأن ظهور تواتر القراءة عند القراء القاء أكثر من غيرهم.

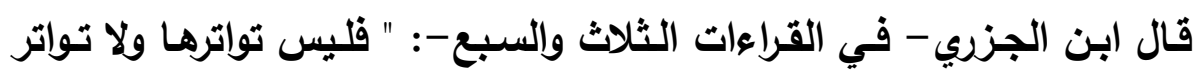
السبع مقتصراً عند أهلها فقط، بل هي متواترة عند كل مسلم سواء قرأ القرأ القرآن

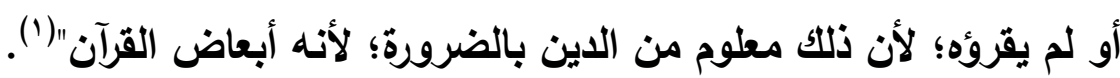

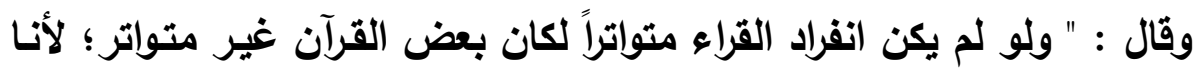

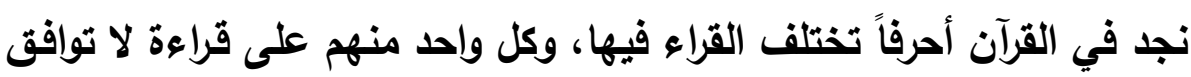

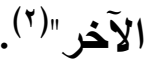

" قال السخاوي: وقد تواتر الخبر عند قوم دون قوم، وإنما أنكرها أبو عمرو؛ 
لأنها لم تبلغه على وجه التواتر"(')

وقال السيوطي : " فربّ متواتر عند قوم دون آخرين، وفي وقت دون آخر "(†)

وقال طـاهر الجزائري : " وأمّا الذي قد يخفى فهو أمر تواترهـا؛ لأنها إنمـا تواترت عند القراء الذين غُنوا بأمر القراءات وضبط وجوهها دون غيرهم، فتواترها ليس كتواتر القرآن"(").

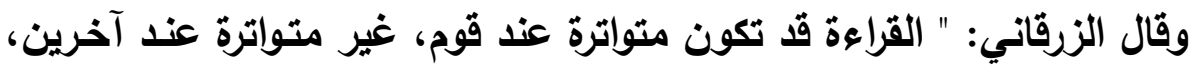

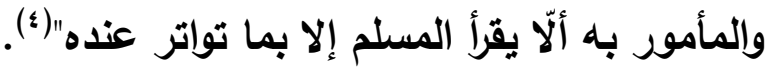
ويلخل تحت هذه القاعدة القواعد التالية : القاعدة الفرعية الأولى : القراءة المتواترة قد تكون متواترة عند قوم دون قوم

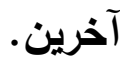

القاعدة الفرعيـة الثانبـة : المعتبر قبـول القراءة وتواترهـا، لا عدم المخالفـة فيها. القاعدة الفرعية الثالثة : تواتر القراءة عند قوم دون قوم آخرين لا يقدح فيها القاعدة الفرعية الثرايعة : من ثبتت عنده قراعة متواترة يجب عليه القراءة بها،

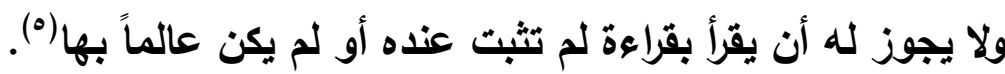
القاعد الفرعية الخامسة : اختلاف القراء في القراءة المتواترة لا ينفي تواترها. القاعد الفرعية السادسة : البسملة آية من الفاتحة في قراءة متواترة سبعية،

$$
\begin{aligned}
& \text { (1) منجد المقرئين ص ماعد ب ـ قاله السخاوي في معرض رده على أبي عمرو بن العلاء }
\end{aligned}
$$

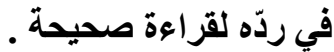

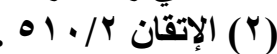

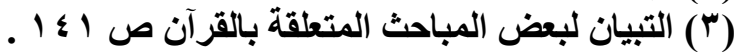

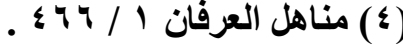

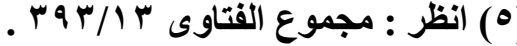




$$
\text { وليست آية من الفاتحة في قراعة متواترة سبعية أخرى غيرها('). }
$$

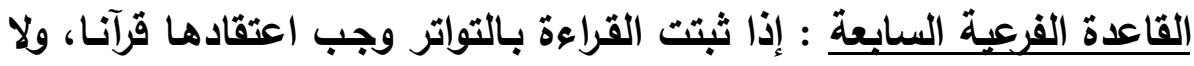

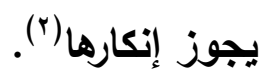

القاعدة الثانية عشرة : أن نسبة القراءات العثر للقراء العشرة اصطلاحية،

$$
\text { وليست نسبة تفرد أو آحاد . }
$$

القراءات كثيرة، اشتـهر منها القراءات العشر، والمقرئسون بـالقراءات العشر عددهم كثير لا يُحصون، ولكن اشتهر منهم القراء العشرة الذين نسبت القراءة

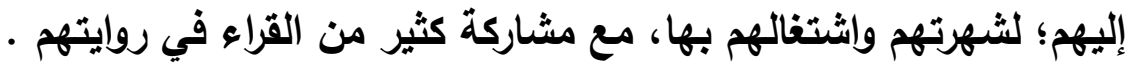

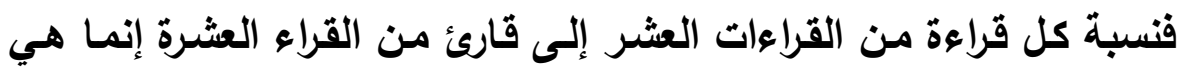
نسبة اصطلاحية، ولم تتسب إليهم لتفردهم بها دون غيرهم .

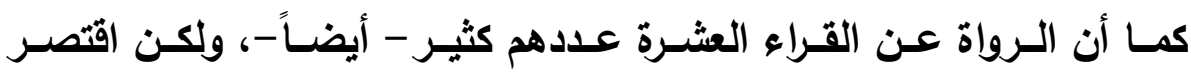
المؤلفون -في الغالب- على راويين لكل قارئ؛ للاختصـار وإثبات الروايـة، وليس تحدياً لعددهم. ويسبب نسبة القراءات العشر للقراء العشرة دون غيرهم وَقَعَعَ الوهْم عند آحاد

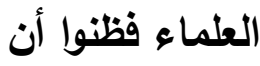
القراءات العشر منسوية إليهم نسبة تفرد، وأن أسـانيد القراء العثرة آحاد،

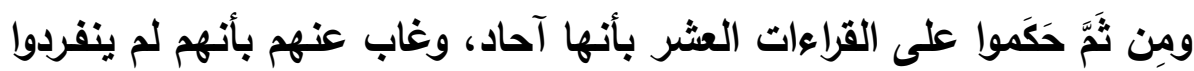

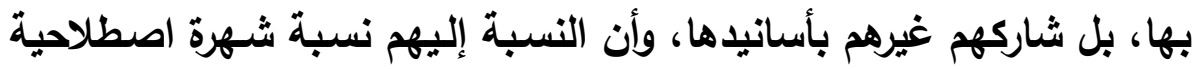

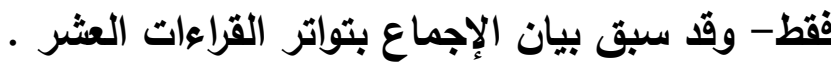


قـال ابن الجزري-في القـراءات العشر -: " اعلـم أن المقرئين بها كثيرٌ لا يُحصون، استوعبتهم في كتاب طبقات القراء "( (1).

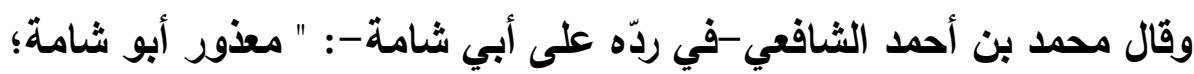

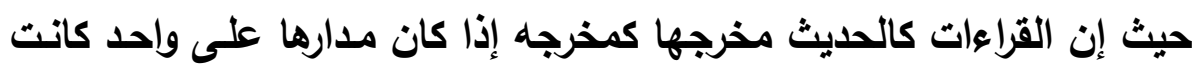

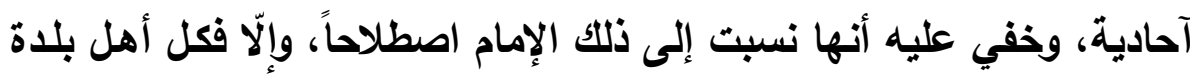

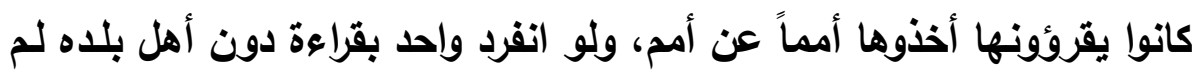

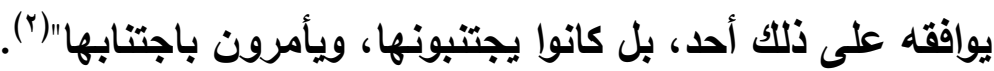
وقال ابن الجزي - بعد أن نقل كراهة بعض السلف نسبة القراعة إلى أحد-: "

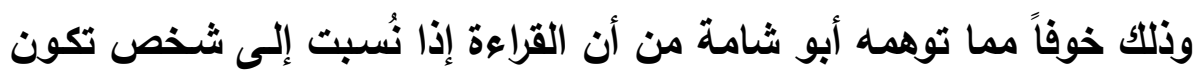

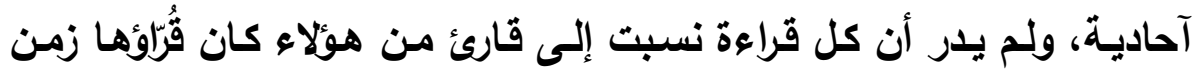
قارئها وقبله أكثر من قرائها في هذا الزمان وأضعافهم" (").

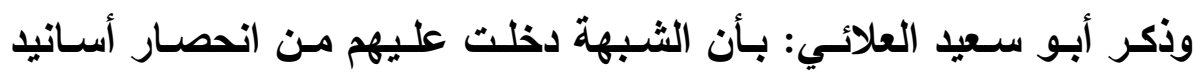

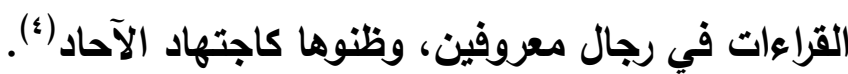

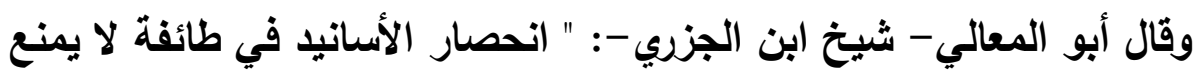

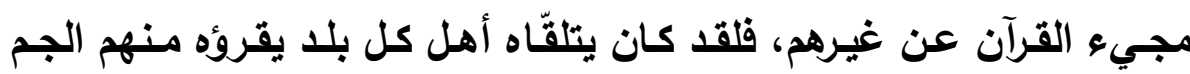
الغفير عن مثلهم، وكذلك دائماً والتواتر حاصل لهم، ولكن الأئمة الذين تصدّوا لضبط الحروف وحفظوا شيوخهم منها

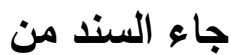
جهنهم" (0).

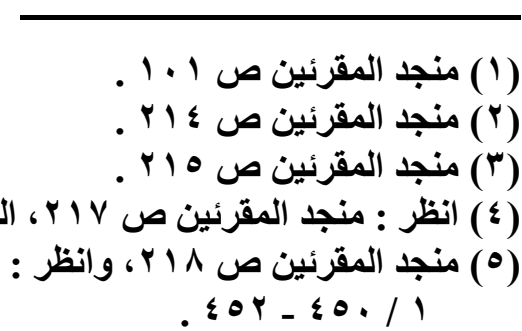


القاعدة الثالثة عشرة : أن ما وراء القراعات العشر شاذ حتى يثبت تواتره.

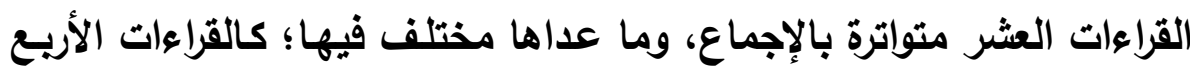

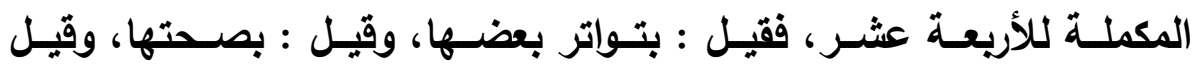

$$
\text { بشذوذها (1). }
$$

وحقيقة هذه القراءات الأربع: منها ما يوافق العشر، ومنها ما انفردت بـه ولم

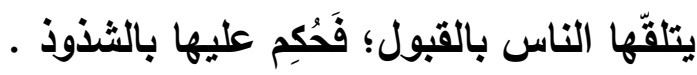

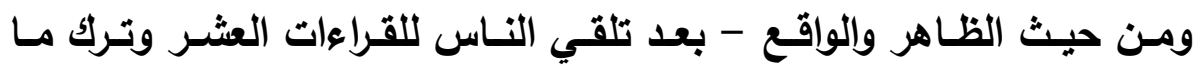
عداها-: فإنها لا توجد الآن قراءة متواترة وراء العشر -كما نص عليه ابن الجزري من قبل()، وأنه ما عدا القراعات العشر يعتبر شاذاً حنى يثبت تواتتره؛

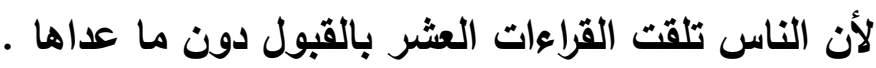
ولكن لا يقطع مطلقاً بأن مـا عدا العشر غير متواتر؛ لأن التواتر قد يكون

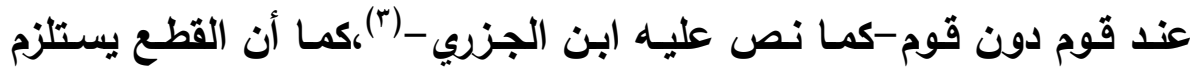
الإحاطة بجميع بلاد المسلمين. فأوّل القاعدة:( أن ما وراء العشر شاذ باذ )؛ هذا هو الظاهر والواقع، والاحتراس

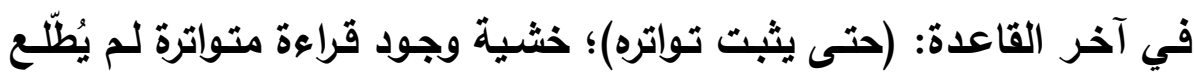
عليها. ولإيضاح حقيقة هذه القاعدة: فإن المعتبر في قبول القراءات اجتماع أركان

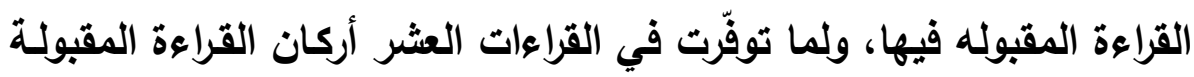

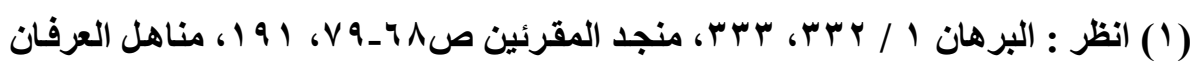
.

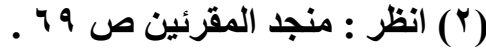

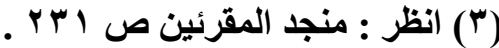


وتلقاهـا النـاس بـالقبول؛ حُكِمِ على قراءة القـراء العشـرة (القراءات العشر)

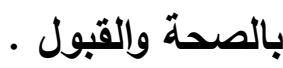

ولما لم يتوفّر في غير القراءات العشر أركان القراءة المقبولة؛ لعدم تواترها أو لعدم تواتر بعضها وترّك الناس القراءة بها؛ حُكِم على قراءة الأربعة المكملين

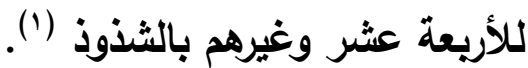

ومما ياخل تحت هذه القاعد القواعد التالية:

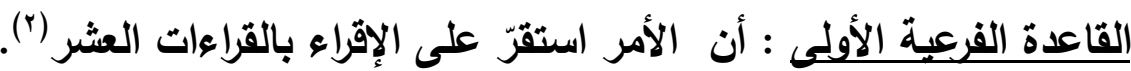
القاعدة الفرعية الثانية : أن التمسك بقراعة عشرة من القراء دون غيرهم إنما هو جمع لبعض

المتأخرين فانتشر ، واستثر الأمر عليه(").

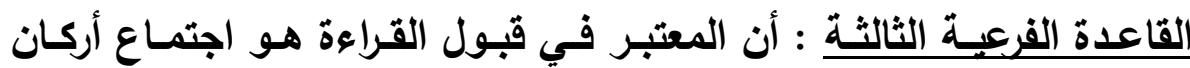

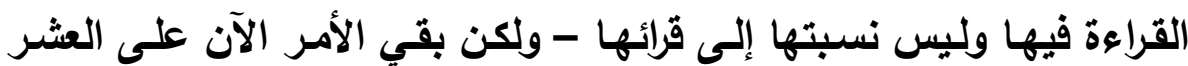
دون غيرها (؛). القاعدة الفرعية الرابعة : أن كل قراءة كان مقروءاً بها ثم ثُركت القراءة بها

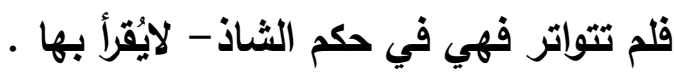

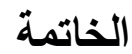

الحمد الله، والصلاة والسلام على رسول الله، أمَّا بعد؛ فمن خلال هذا البحث

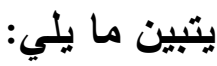
1-أن القرآن كلام الله لفظاً ومعنى، قطعي الثبوت، لا تجوز قراءته

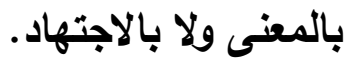

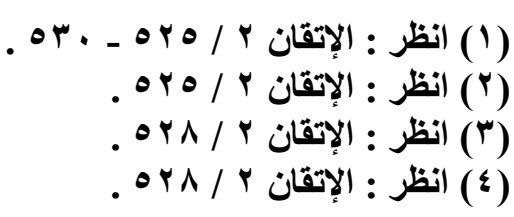


r- أن الله تكفل بحفظ القرآن فلا يلخله التغيير والتبديل.

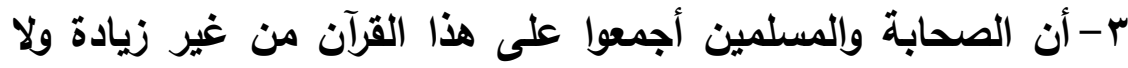
نقصان، وأن الزيادة والنقصان في القرآن كفر .

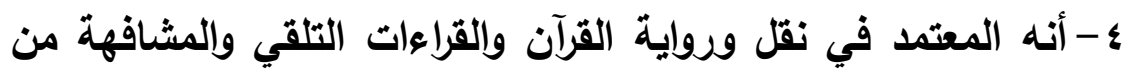
الأئمة الثقات بعضهم عن بعض؛ لأن القراءة سنة متبعة يأخذها الآخر عن الأول، وأما المصحف فهو مساند للحفظ والرواية.

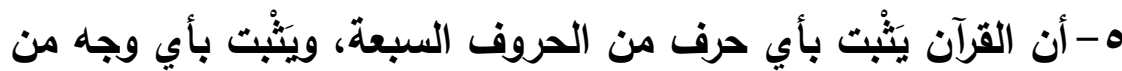

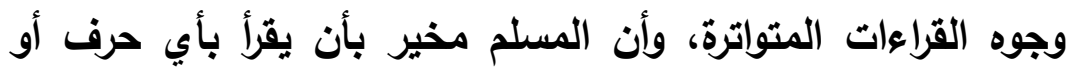
قراءة متواترة، وأن كلاً منها قرآن قائم بذاته.

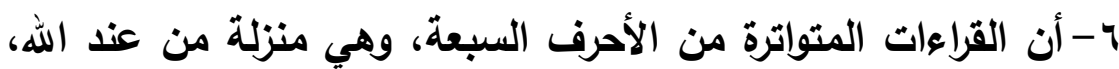
قرأ بها النبي- صلى الله عليه وسلم- والصحابة ومن بعدهم. V- أن أعداد القراءات كثيرة، ولكن الثتهر منها القراءات العشر، وإستقر الإقراء عليها. ^- أن الإجماع قائم على قبول القراءات العشر كلها، وأنها متواترة اتفاقاً

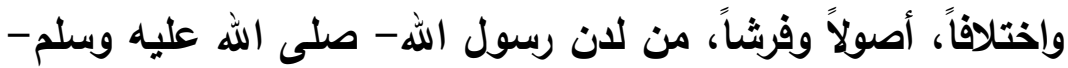
إلى منتهاها، ولا يقدح فيها شذوذ المخالفِ أو المشاحة في الاصطلاح.

• 1-أن نسبة القراءات للقراء العشرة إنما هي نسبة اصطلاحية وليست

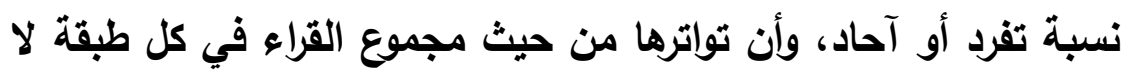
من حيث أسانيد القراء، وأن تواترها عند قوم كتواترها عند قوم آخرين. 11-أن ما وراء العشر شاذ حتى يشبت تواتره. 


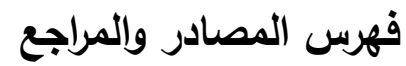

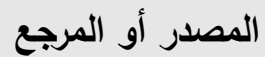

إتحاف فضلاء البشر بالقراءات الأربعة عشر : لأحمد بن محمد البنّا.

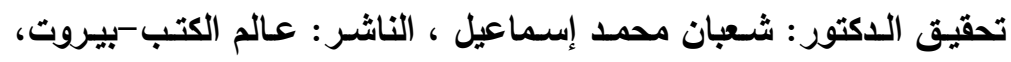

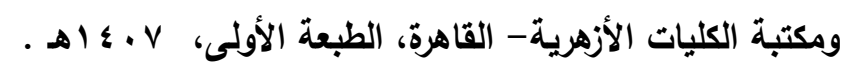

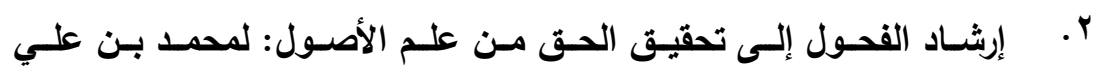

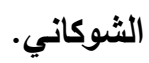

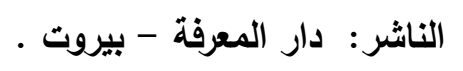

r. أصل الاعتقاد - دراسة حديثية: لعمر بن سليمان الأثقر.

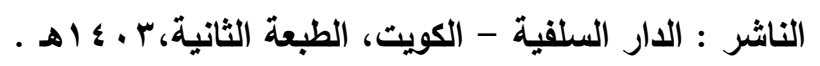

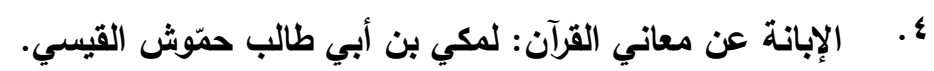

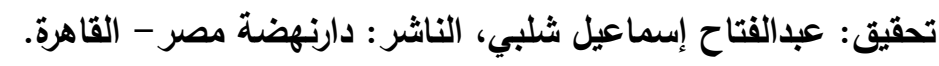

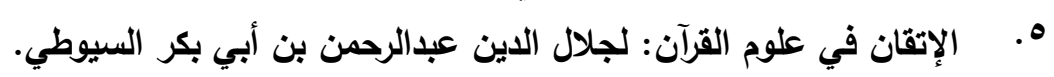

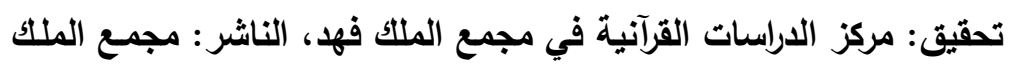

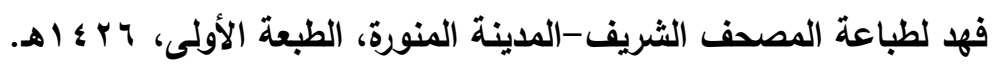

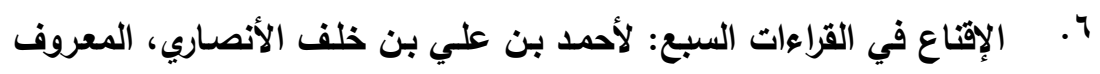

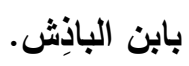
تحقيق الاكتور: عبدالمجيد قطماش، الناشر :مركز البحث العلمي في جامعة

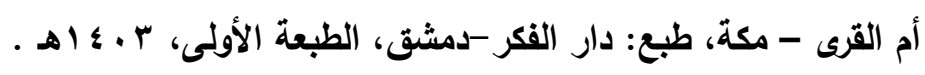

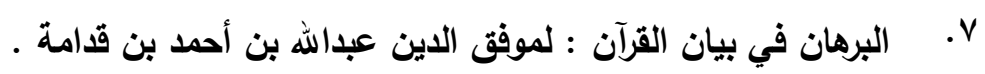

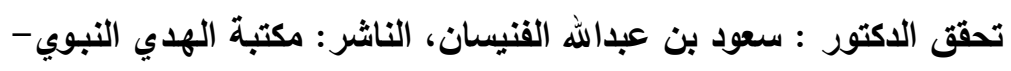

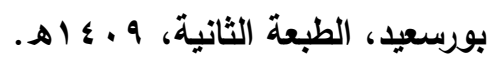

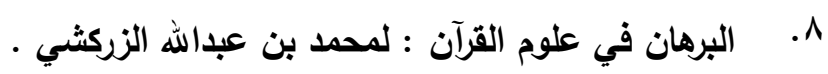

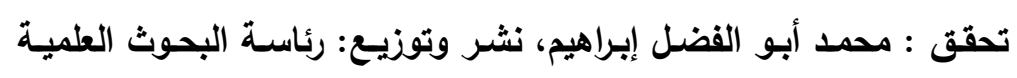

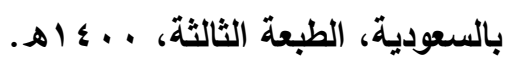

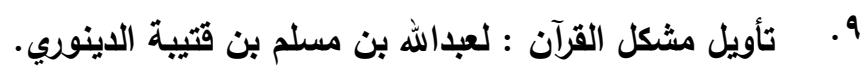


شرحه ونشره : أحمد صقر ، الناشر : المكتبة العلمية.

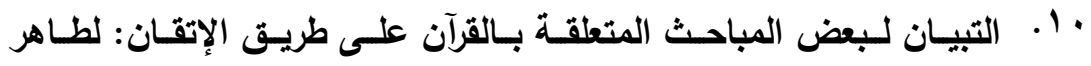

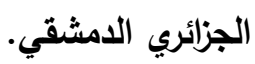

اعتــى بـهـ: عبدالفتاح أبـو غدة، الناثـر : مكتبـة المطبوعـات الإسـلامية

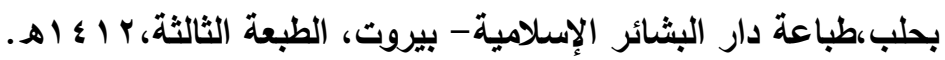

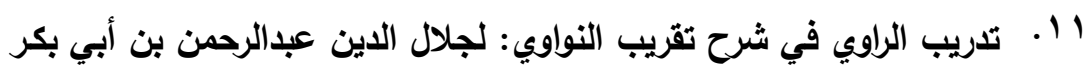
- السيوطي تحقيق الدكتور : أحمد عمر هاشم ، الناشر: دار الكتاب العربي- بيروت،

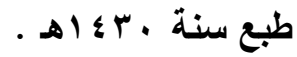

r ا. التذكرة في القراءات: لأبي الحسن طاهر بن عبد المنعم بن غلبون.

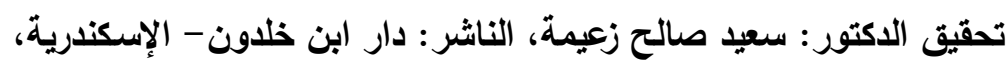

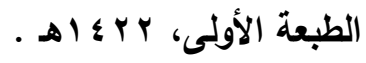

r ا. التسهيل لطلوم التنزيل: لأبي القاسم محمد بن أحمد بن جزي الكلبي.

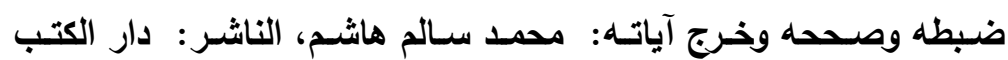

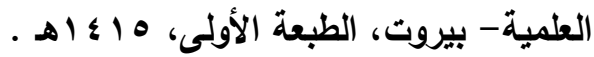

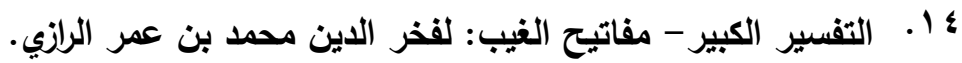

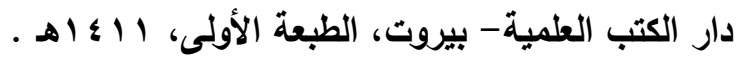

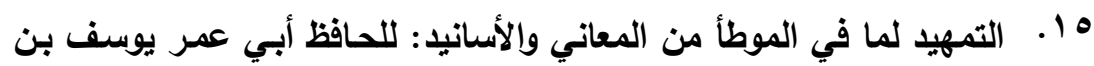
عبدالله بن عبدالبر النمري الأندلسي. تحقيق : مصطفى العلوي ومحمد البكري، الناشر : وزارة الأوقاف والثوؤون

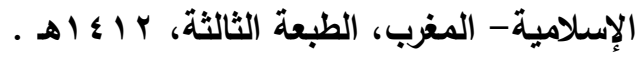

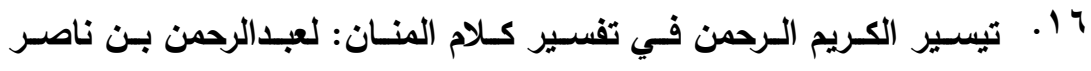
السعدي. اعتنى بـه : سـعد بن فواز الصميل، الناشر : دار ابن الجوزي - الدمام،

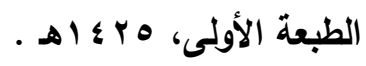
IV التيسير في القراءات السبع: للإمام أبي عمرو عثمان بن سعيد الداني.

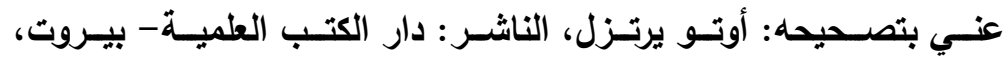




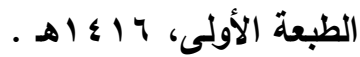

1 1. .جامع البيان في تأويل القرآن : لأبي جعفر محمد بن جرير الطبري .

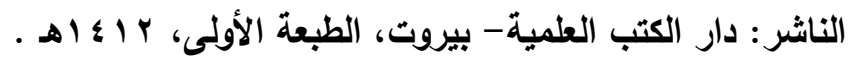

19. الجامع لأحكام القرآن:لأبي عبدالله محمد بن أحمد الأنصاري القرطبي.

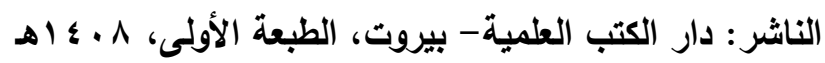

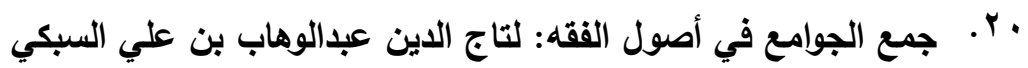

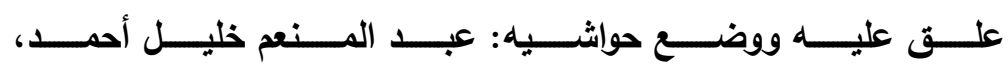

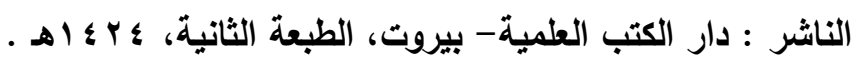

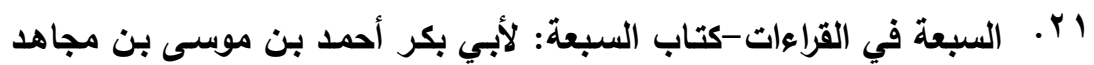

التميمي البغدادي.

تحقيق الاكتور : شوقي ضيف، الناشر: دار المعارف- مصر، طبع سنة

. $) 9 \vee r$

r r r. السنن الكبرى : للإمام أبي بكر أحمد بن الحسين البيهقي.

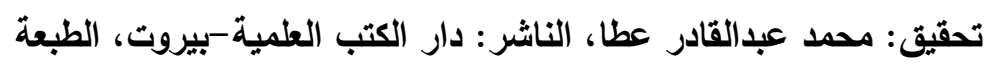

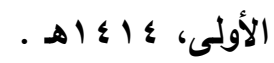

r r. شرح الكوكب المنير- المسمّى بمختصر التحرير أو المختصر المبتكر شرح

المختصر: لمحمد بن عبدالعزيز الفتوحي الحنبلي المعروف بابن النجار.

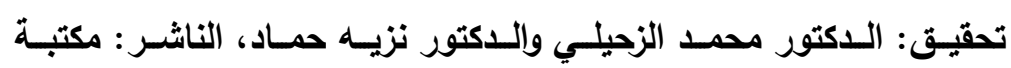

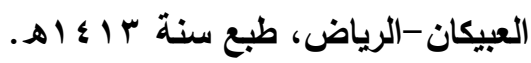

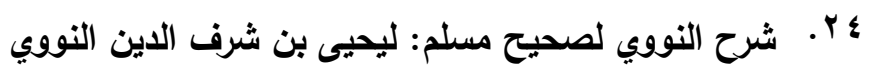

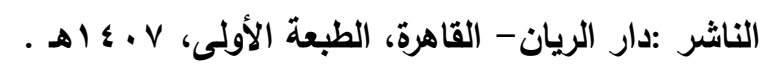

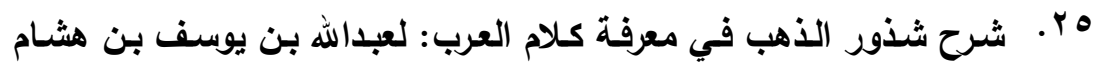

الأنصاري المصري.

تحقيق : محمد محيي الدين عبد الحميد، الناشر : دار الفكر.

צr. شرح مختصر الروضة: لسليمان بن عبدالقوي الطوفي.

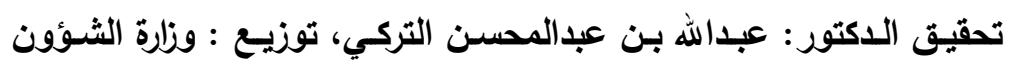

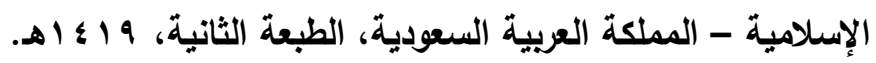


الثفا: للقاضي عياض ، وشرحه: للملّا علي القاري.

الناشر : دار الكتب العلمية- بيروت .

1 r. صحيح البخاري- الجامع الصحيح: للإمام أبي عبد الله محمد بن إسماعيل

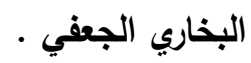

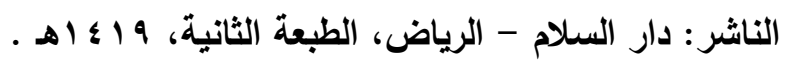

9. . صحيح مسلم: لأبي الحسين مسلم بن الحجاج القشيري النيسابوري.

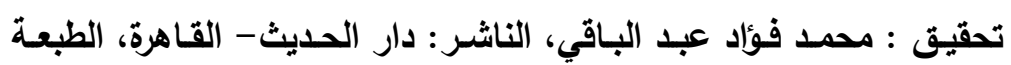

الثانية، r إ؛ الهـ . له

•r. عمدة الحفاظ في تفسير أشرف الألفاظ: لأحمد بن يوسف المعروف

بالسمين الحلبي.

تحقيق: محمد التونجي، الناشـر: عـالم الكتب- بيروت، الطبعة الأولى،

\& إ أهـ

اس إية النهاية في طبقات القراء: لأبي الخير محمد بن محمد بن الجزري.

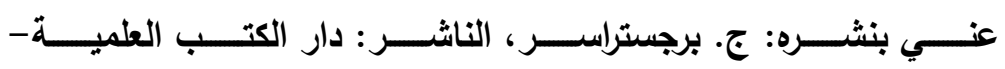

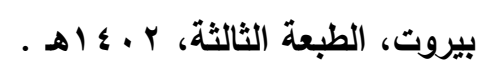

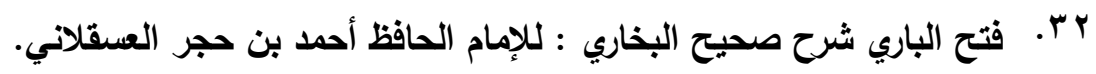

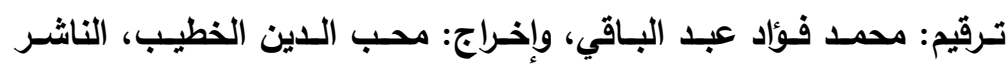

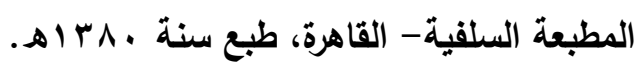

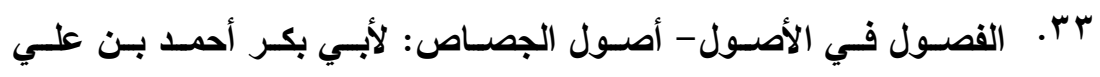

الجصاص الزازي.

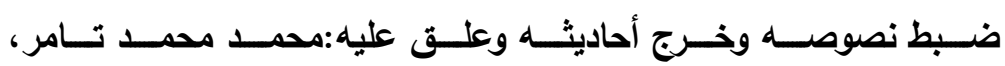

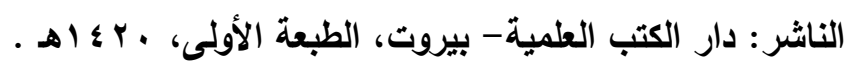

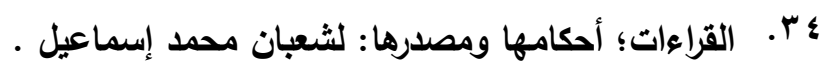

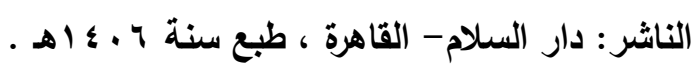

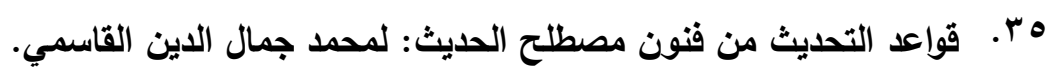

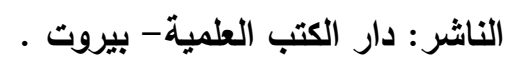

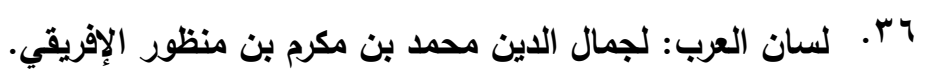




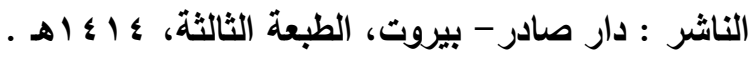

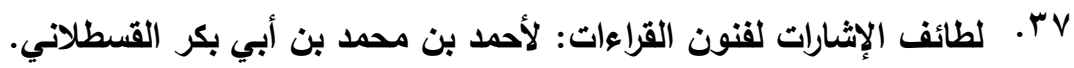

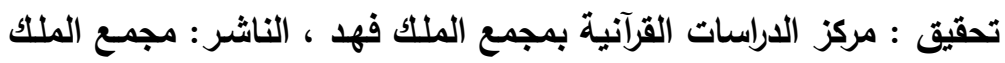
فها لطباعة المصحف الثريف-المدينة المنورة.

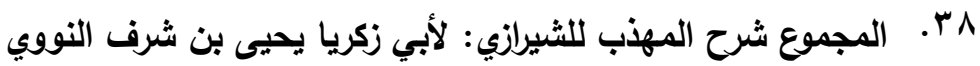

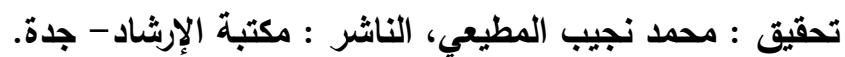

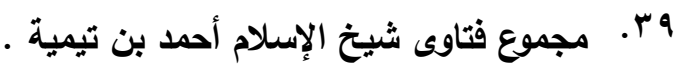

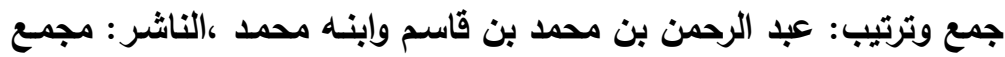

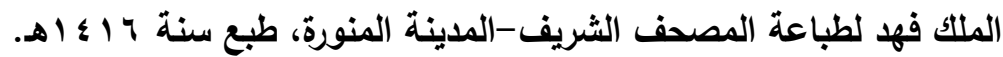
• ع. المحلى بالآثار : لعلي بن أحمد بن حزم الأندلسي. تحقيق الدكتور: عبد الغفار البنداري، الناشر : دار الكتب الانب العلمية-بيروت،

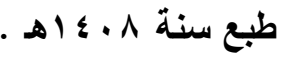
اءـ. مختصـر الأصـول - مختصـر منتهـى السـؤل والأمسل فـي علمـــ الأصـول

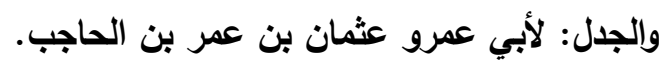

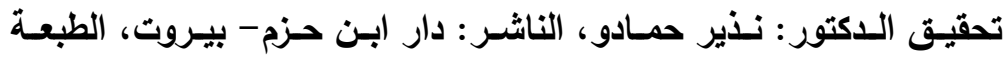

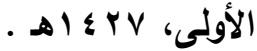
r \&. مدخل إلى علم القراءات: للاكتور شعبان محمد إسماعيل.

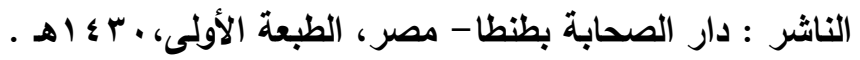
r ؟. مذكرة في أصول الفقه: لمحمد الأمين بن محمد المختار الثنقيطي.

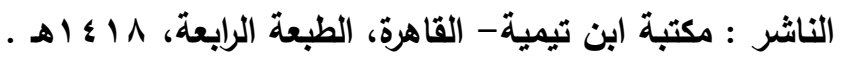

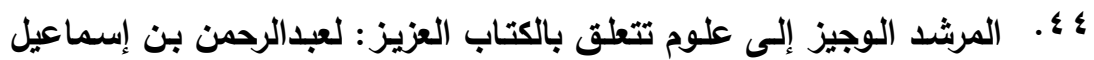
المعروف بأبي شامة المقدسي.

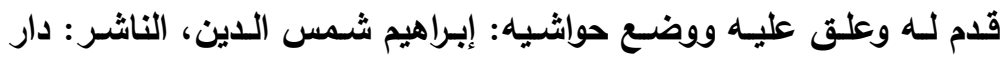

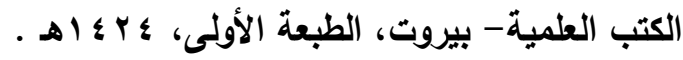
ه ؛. المصـاحف- كتـاب المصـاحف: لأبسي بكر عبدالله بـن أبسي داود سـليمان السجستاني. الناشر : دار الكتب العلمية - بيروت، الطبعة الأولى ، هـ ـ ـ اهـ ـ. 
مصنف عبدالرناق: للإمام أبي بكر عبدالرناق بن همام الصنعاني. .$\leqslant 7$

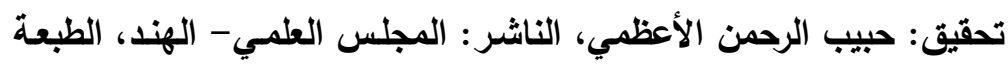

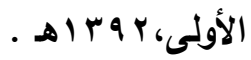

\& V . معترك الأقران في إعجـاز القرآن: لجـلال الدين عبدالرحمن بـن أبـي بكر السيوطي. ضبطه وصححه وكتب فهارسـه: أحمد شـس الدين، الناثـر : دار الكتب

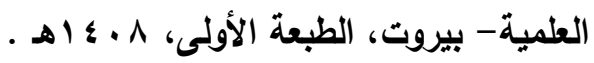

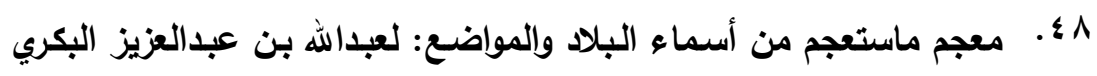
الأندلسي. تحقيـق: مطفى الستّقّا، الناشـر : عـالم الكتبـ- بيـروت، الطبعـة الثالثـة، . معرفة القراء الكبار على الطبقات والأعصار : لمحمد بن أحمد بن عثمان .$\leqslant 9$ الأهبي. تحقيق : طيار آلتي قولاج، الناشر: مركز البحوث الإسلامية التابع لوقف

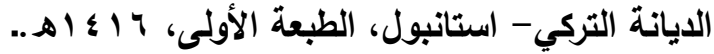

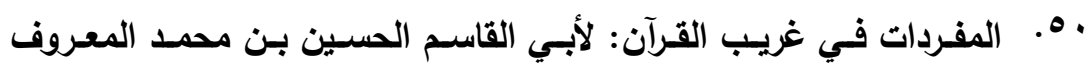
بالراغب الأصفهاني. تحقيق : محمد سيد كيلاني، الناشر:دار المعرفة-بيروت.

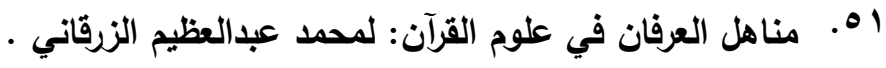
خرج آياته وأحاديثه ووضع حواثيه: أحمد شمس الدين، الناشر :دار الكتب

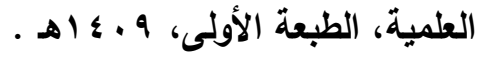

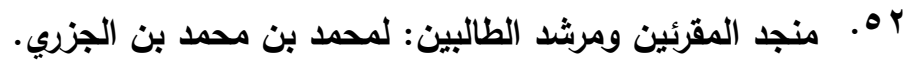

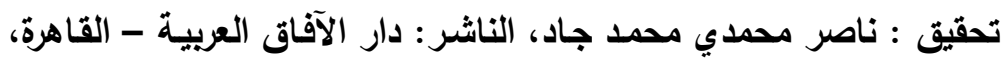

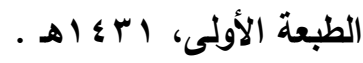
rه. منع الموانع عن جمع الجوامع في أصول الفقه: لتاج الدين عبدالوهاب بن علي السبكي. تحقيـق : ســيد عـــي الحميـري، الناشــر : دار البشـــائر الإســلامية- 


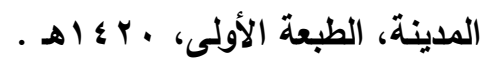

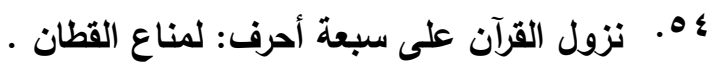

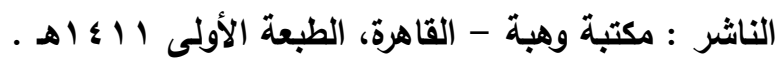

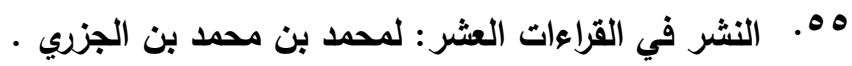

اعتنى بـه : نجيب الماجدي، الناشر: المكتبة العصرية- بيروت، الطبعة الجرية

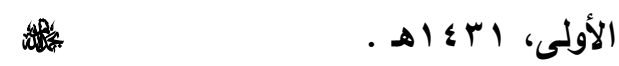

